ANDREA ROMANO DOS SANTOS

O DESENVOLVIMENTO DO MERCADO DE EDIFÍCIOS DE ESCRITÓRIOS PARA

LOCAÇÃO NA CIDADE DE SÃO PAULO IMPULSIONADO PELA

SECURITIZAÇÃO

Dissertação apresentada à Escola Politécnica da

Universidade de São Paulo para obtenção do

Título de Mestre em Engenharia

São Paulo 


\section{O DESENVOLVIMENTO DO MERCADO DE EDIFÍCIOS DE ESCRITÓRIOS PARA LOCAÇÃO NA CIDADE DE SÃO PAULO IMPULSIONADO PELA SECURITIZAÇÃO}

Dissertação apresentada à Escola Politécnica da Universidade de São Paulo para obtenção do Título de Mestre em Engenharia

Área de Concentração:

Gerenciamento de Empresas e Empreendimentos na Construção Civil

Orientador:

Prof. Doutor João da Rocha Lima Jr. 
Este exemplar foi revisado e alterado em relação à versão original, sob responsabilidade única do autor e com a anuência de seu orientador.

São Paulo, 28 de julho de 2006.

Assinatura do autor

Assinatura do orientador

FICHA CATALOGRÁFICA

Santos, Andrea Romano dos

O desenvolvimento do mercado de edifícios de escritórios para locação na cidade de São Paulo impulsionado pela securitização / A.R. dos Santos. -- ed.rev. -- São Paulo, 2006. $147 \mathrm{p}$.

Dissertação (Mestrado) - Escola Politécnica da Universidade de São Paulo. Departamento de Engenharia de Construção Civil.

1.Edifícios comerciais 2.Escritórios 3 .Locação de imóveis São Paulo(SP) 4.Securitização I.Universidade de São Paulo. Escola Politécnica. Departamento de Engenharia de Construção Civil II.t. 
Aos meus pais Claudio e Neuza (in memorian) que, através de seu incentivo à educação e seu exemplo de obstinação, me deram a força necessária para cumprir mais esta importante tarefa em minha vida. 


\section{AGRADECIMENTOS}

Ao meu orientador, Prof. Doutor João da Rocha Lima Jr., por todo o suporte ao desenvolvimento deste trabalho e pelas críticas construtivas e oportunas.

A todos os professores do GEPE-GER que contribuíram para meu crescimento intelectual ao longo deste programa de Mestrado.

Aos meus colegas do GEPE-GER pela cumplicidade e incentivo demonstrados.

A meu noivo, Antonio, por todo o incentivo, carinho, respeito e compreensão durante as horas de afastamento para o desenvolvimento deste trabalho. 


\section{RESUMO}

A construção civil, e mais especificamente os empreendimentos de base imobiliária, necessitam de grandes volumes de recursos concentrados em um curto período para o desenvolvimento de seus produtos, cujo payback ${ }^{l}$ é de horizonte largo, dependendo assim de ferramentas que permitam alavancar os empreendimentos para que os recursos sejam utilizados nas atividades fim das empresas deste setor. Desta forma, o setor ganha em produtividade, competitividade e agilidade, incluindo a diminuição da rotatividade de sua mão-de-obra.

A securitização vem ao encontro dos interesses do setor por ser um sistema flexível para a captação dos recursos que possibilita o re-direcionamento de recursos da poupança brasileira para o mercado de empreendimentos de base imobiliária.

É neste contexto que o presente trabalho apresenta a securitização de empreendimentos de base imobiliária, mais especificamente de edifícios de escritório voltados à locação, como um vetor de impulsão deste mercado a partir do momento que se torna uma alternativa de investimento atrativa aos poupadores, da mesma forma como é vista em países onde este já é um procedimento consagrado. Como o Brasil ainda tem um mercado incipiente, o mercado americano, que já apresenta maturidade, será utilizado como referência para as projeções que serão feitas acerca do desenvolvimento da securitização no Brasil.

Com isto, com a projeção das expectativas para o mercado paulistano de edifícios de escritórios e com a demonstração da atratividade dos papéis, pretende-se mostrar que a securitização é um meio de funding ${ }^{2}$ que pode sustentar grande parte da demanda por recursos para a implantação de novos produtos deste mercado.

\footnotetext{
${ }^{1}$ Indicador que mostra a possibilidade da retomada da capacidade de investimento daquele que imobiliza seus recursos em determinado empreendimento. Trata-se, portanto, de um indicador do prazo de recuperação da capacidade de investimento. Sendo assim, payback longo implica na necessidade de imobilização de recursos por períodos longos para que se retome a capacidade de investimento inicial.

${ }^{2}$ Palavra inglesa que se refere aos recursos destinados a um propósito específico. No texto, funding será utilizada em referência à aglutinação dos recursos necessários para a implantação de determinado empreendimento, sejam eles recursos do próprio empreendedor, recursos de financiamento, ou de terceiros.
} 


\begin{abstract}
Construction industry, specifically, real state ventures, needs great amount of capital concentrated on a short period of time in order to develop its products, which have a long term payback.
\end{abstract}

For that reason, this sector become dependant on methods that allows the leverage of undertakings, so the entrepreneurs' resources can be employed on the their core business.

Such methods allow this sector to have significant gains in terms of productivity, competitiveness and agility, including also the diminution of its employees' turnover.

The securitization comes across the interests of this sector, as it is a flexible financial resource's gathering system that conducts to the steering of Brazilian's savings accounts to the real state market.

On this context, the present work introduces the real state ventures securitization, focused on office buildings, as an important tool for the development of this market, as it becomes an attractive investment opportunity when compared with the savings options available on the market.

As the Brazilian market is still incipient, the American market, that shows more maturity, will be used as benchmark for projections concerning the securitization's development on Brazil.

This projection, combined with São Paulo's office building market analysis and the demonstration of the attractiveness of the securities as an investment option, will be used to demonstrate that the securitization is a funding structure that can sustain great part of the capital demand for the development of new ventures on this market. 


\section{SUMÁRIO}

1 INTRODUÇÃO E JUSTIFICATIVA

2 OBJETIVO. .21

3 ESTRUTURA DO TRABALHO .23

3. 1 Metodologia Da PESQUisa

4 O MERCADO DA CONSTRUÇÃO CIVIL

4. 1 IMPORTÂNCIA E PECULIARIDADES

4. 2 CLASSIFICAÇÃo BÁSICA DOS EMPREENDIMENTOS DA CONSTRUÇÃo CIVIL

4.2.1 Empreendimentos Imobiliários. .29

4.2.2 Empreendimentos de Base Imobiliária (EBI). 31

5 O MERCADO DE EDIFÍCIOS DE ESCRITÓRIOS NA CIDADE DE SÃO PAULO . .33

5. 1 EDIFÍCIOS DE ESCRITÓRIOS

5. 2 A EVOLUÇão DO PRODUTO EDIFÍCIO DE ESCRITÓRIOS

5. 3 CLASSIFICAÇ̃̃o DOS EDIFÍCIOS DE ESCRITÓRIOS

5. 4 A EVOLUÇão DO MERCADO DE EDIFíCIOS DE ESCRITÓRIOS NA CIDADE DE SÃo PAULO

5.4.1 Indicadores de mercado e sua evolução .45

5. 5 A COMPLEXIDADE dos Ciclos DOS EELS

5.5.1 Os quadrantes dos ciclos de comportamento dos EELs. 53

5. 6 RISCOS DO INVESTIMENTO NAS DIFERENTES ETAPAS DO CICLO DE VIDA DO EEL 
5.8.1 Absorção do estoque ocioso de EEL de alto padrão na cidade de São Paulo

5.8.2 Recuperação dos patamares de atratividade de investimento no setor de EELs na cidade de São Paulo .67

6.4.2 Para o investidor:

6.4.3 Para o desenvolvimento do mercado de EELs: ..... 80

6. 5 POSICIONAMENTO DO INVESTIMENTO EM VETORES DE SECURITIZAÇÃO EM RELAÇÃO AO INVESTIMENTO IMOBILIÁRIO TRADICIONAL

6.7.1 Fundo de Investimento Imobiliário (FII) 
6.11.1 Garantia de renda no período de implantação

6.11.2 Garantia de renda mínima no início do ciclo operacional.

6.11.3 Securitização com emissão de títulos seniores protegidos por títulos subordinados..... .96

6.11.4 Conformação do fluxo de retorno dos títulos segundo as necessidades dos investidores-chave .98

6.11.5 Garantias dependentes de terceiros. 99

6.11.6 A importância das grandes marcas 100

6. 12 O MERCADO NORTE-AMERICANO COMO PARADIGMA 100

6.12.1 Histórico.

6.12.2 Tipos de REIT 103

6. 13 O MERCADO BRASILEIRO 104

6.13.1 Evolução do investimento em EBI no mercado brasileiro....................................................... 105

6.13.2 O principal investidor no mercado brasileiro ...................................................................... 106

$7 \quad$ ATRATIVIDADE DOS TÍTULOS SECURITIZADOS ..........................................................................112

7. 1 CARTEIRA DE REFERÊNCIA $\quad 113$

$\begin{array}{llr}7.2 & \text { CADERNETA DE POUPANÇA } & 116\end{array}$

7. 3 INVESTIMENTOS FINANCEIROS COM RENDIMENTO ATRELADO AO CDI 117

$\begin{array}{llr}7.4 & \text { CARTEIRA DE AÇÕES } & 117\end{array}$

$\begin{array}{lll}\text { 7. } 5 & \text { FUNDO DE INVESTIMENTO IMOBILIÁRIO (FII) } & 118\end{array}$

$\begin{array}{llr}\text { 7. } 6 \text { COMENTÁRIOS E CONSIDERAÇÕES } & 121\end{array}$

8 ESTUDO SOBRE O DIRECIONAMENTO DA POUPANÇA BRASILEIRA PARA A

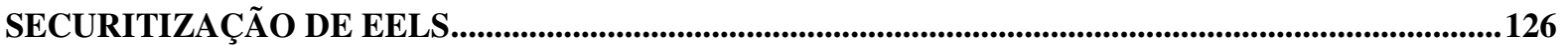

8. 1 CAPITALIZAÇÃO DE EELS SECURITIZADOS NO MERCADO BRASILEIRO 126 
8. 2 VOLUME DE POUPANÇA CONSERVADORA A SER RE-DIRECIONADO PARA TÍTULOS DE SECURITIZAÇÃO DE EELS

8. 3 O SIGNIFICADO DO RE-DIRECIONAMENTO DE RECURSOS DA POUPANÇA PARA O MERCADO DE EEL 138

9 CONSIDERAÇÕES FINAIS. 140

10 LISTA DE REFERÊNCIAS 


\section{LISTA DE FIGURAS}

Figura 1 - Evolução de indicadores de mercado de edifícios de altíssimo padrão em São Paulo - classe AA (fonte: Jones Lang LaSalle - Balanço de 2002)

Figura 2 - Evolução de indicadores de mercado de edifícios de alto padrão em São Paulo -

classe A (fonte: Jones Lang LaSalle - Balanço de 2002)

Figura 3 - Etapas presentes nos ciclos de evolução do mercado de EELs. 53

Figura 4 - Remuneração de edifícios comerciais de alto padrão nos mercados de São Paulo (fonte: Rocha Lima e Alencar, 2004) 63

Figura 5 - Absorção de edifícios comerciais de alto padrão nos mercados de São Paulo Evolução do PIB (\%) - 4,5 e 2,0 (fonte: Rocha Lima e Alencar, 2004)..... .66

Figura 6 - Remuneração de edifícios comerciais de alto padrão nos mercados de São Paulo, considerando a evolução média anual do PIB de 4,5\% (fonte: Rocha Lima e Alencar, 2004a) .68

Figura 7 - Remuneração de edifícios comerciais de alto padrão nos mercados de São Paulo considerando a evolução média anual do PIB de 2,0\% (fonte: Rocha Lima e Alencar, 2004a) .68

Figura 8 - Hierarquia dos negócios no mercado de EELs (adaptação de Rocha Lima, 2004) 82

Figura 9 - Fases do ciclo de implantação e comercialização de um EEL e os recursos necessários 90 
Figura 10 - Derivação de recursos da colocação dos títulos lastreados em ativos imobiliários (fonte: Unitas, 2003)

Figura 11 - Ilustração de fluxo de renda garantida pelo empreendedor e RODi distribuídos para os títulos de securitização de um EEL: proteção dos investidores através de remuneração no período de implantação 93

Figura 12 - Ilustração de fluxo de renda garantida pelo empreendedor e RODi distribuídos para os títulos de securitização de um EEL: proteção dos investidores através de remuneração no período de inserção de mercado 95

Figura 13 - Ilustração de fluxo de RODi distribuídos entre títulos de securitização de um EEL: mitigação de riscos via identificação da parcela do fluxo sujeita a riscos. 97

Figura 14 - Ilustração de fluxo de RODi distribuídos entre títulos de securitização de um EEL: conformação do retorno dos títulos às necessidades do investidor. 98

Figura 15 - Evolução da capitalização dos REITs americanos de 1971 a 2004 (fonte: NAREIT) 101

Figura 16 - Evolução da participação do investimento em imóveis e em renda fixa na carteira dos fundos de pensão (fonte de dados: ABRAPP) 110

Figura 17 - Renda e Valor da Carteira Imobiliária em Reais nominais (fonte: Rocha Lima; Takaoka, 2006) 116

Figura 18 - Renda e Valor da Carteira Imobiliária em Reais da base - janeiro/95 (fonte: Rocha Lima; Takaoka , 2006) 116 
Figura 19 - Renda mensal e Valor da Carteira "FII + caderneta de poupança" em Reais nominais (fonte: Rocha Lima; Takaoka, 2006) 120

Figura 20 - Renda mensal e Valor da Carteira "FII + caderneta de poupança" em Reais da base - janeiro/95 (fonte: Rocha Lima; Takaoka, 2006)

Figura 21 - Valor das carteiras em Reais nominais (fonte: Rocha Lima; Takaoka, 2006).... 123

Figura 22 - Valor das carteiras em Reais da base - janeiro/95 (fonte: Rocha Lima; Takaoka, 2006) 124

Figura 23 - Poupança em REITs (EEL) frente ao PIB americano 128

Figura 24 - Projeções de recursos novos na securitização de EELs: meta acumulada. Valores em R \$ bilhões de dezembro de 2004 (simulação para evolução anual do PIB de 4,5\%)

Figura 25 - Projeções de recursos novos na securitização de EELs: meta acumulada. Valores em R \$ bilhões de dezembro de 2004 (simulação para evolução anual do PIB de 2,0\%)

Figura 26 - Projeções buscando a meta de 0,32\% em 10 anos da securitização de EELs frente ao PIB e a projeção conservadora (simulação para evolução anual do PIB de 4,5\%) ... 132

Figura 27 - Projeções buscando a meta de 0,32\% em 10 anos da securitização de EELs frente ao PIB e a projeção conservadora (simulação para evolução anual do PIB de 2,0\%) ... 133

Figura 28 - Expressão do re-direcionamento da poupança financeira para securitização de EELs (simulação para evolução anual do PIB de 4,5\%) 136 
Figura 29 - Expressão do re-direcionamento da poupança financeira para securitização de EELs (simulação para evolução anual do PIB de 2,0\%) 


\section{LISTA DE TABELAS}

Tabela 1 - As etapas da implantação de um EEL e a demanda por recursos 89

Tabela 2 - Composição da carteira dos fundos de pensão ao longo da última década (fonte: ABRAPP - Associação brasileira das entidades fechadas de previdência complementar)

Tabela 3 - Rentabilidade do FII Torre Almirante, já deduzidas as taxas de administração, performance e demais custos do fundo (fonte: Caixa Econômica Federal)

Tabela 4 - O PIB americano e a capitalização dos REITs

Tabela 5 - Projeções da participação da poupança na securitização de EELs frente ao PIB brasileiro (simulação para evolução anual do PIB de 4,5\%) 130

Tabela 6 - Projeções da participação da poupança na securitização de EELs frente ao PIB brasileiro (simulação para evolução anual do PIB de 2,0\%)

Tabela 7 - Recursos de poupança disponíveis para securitização de EELs: expressão do redirecionamento (simulação para evolução anual do PIB de 4,5\%)

Tabela 8 - Recursos de poupança disponíveis para securitização de EELs: expressão do redirecionamento (simulação para evolução anual do PIB de 2,0\%) 135 


\section{LISTA DE ABREVIATURAS E SIGLAS}

ABR - Área Bruta Rentável

ABRAPP - Associação Brasileira das Entidades Fechadas de Previdência Complementar

BACEN - Banco Central do Brasil

BNDES - Banco Nacional de Desenvolvimento Econômico e Social

BOVESPA - Bolsa de Valores de São Paulo

CGPC - Conselho de Gestão da Previdência Complementar

CMN - Conselho Monetário Nacional

CVM - Comissão de Valores Mobiliários

CEPAC - Certificado de Potencial Adicional de Construção

EBI - Empreendimento de Base Imobiliária

EEL - Edifício de Escritórios para Locação

EMC - Equity Market Capitalization

FII - Fundo de Investimento Imobiliário

FINEM - Financiamento a Empreendimentos (linha de crédito do BNDES)

FRA - Fundo de Reposição de Ativos

IBOVESPA - Índice de Desempenho da Bolsa de Valores de São Paulo

IGP-M - Índice Geral de Preços de Mercado

NASDAQ - National Association of Securities Dealers Automated Quotation System

NAREIT - National Association of Real Estate Investment Trusts 
PFn - Poupança Financeira: Recursos Novos

PFt - Poupança Financeira: Recursos Acumulados

PIB - Produto Interno Bruto

RAG - Renda Adicional Garantida

REIT - Real Estate Investment Trust

Ren - Recursos Novos de Investimento em Real Estate

RODi - Resultado Operacional Disponível no período i

NRE - Núcleo de Real Estate da Escola Politécnica da USP

SFH - Sistema Financeiro da Habitação

SFN - Sistema Financeiro Nacional

SPC - Secretaria de Previdência Complementar

SPE - Sociedade de Propósito Exclusivo 


\section{INTRODUÇÃo E JUSTIFICATIVA}

A implantação dos empreendimentos da Construção Civil demanda grande quantidade de recursos concentrada em um curto período, o que torna a captação dos mesmos uma etapa essencial e, em muitos casos, complexa para o desenvolvimento do produto. Nestes empreendimentos que exigem aporte de recursos elevado e concentrado, um Project Finance ${ }^{3}$ adequado, além de viabilizar a concretização do mesmo, induz à melhoria da qualidade econômica do investimento.

De outro lado, para atender a esta demanda por recursos, tem-se: [i] os grandes investidores que buscam diversificar seus investimentos para obter um portfólio equilibrado, de maneira a mitigar riscos e manter padrões de rentabilidade aceitáveis; [ii] pequenos e médios investidores que buscam investimentos imobiliários com foco no incremento do orçamento familiar e na aposentaria; [iii] investidores institucionais, como os fundos de pensão, que buscam investimentos de baixo risco com retorno homogêneo por longos prazos, para sustentar a aposentadoria de seus clientes; [iv] os financiamentos bancários, vetores mais comuns para a captação de recursos, que implicam na dependência, por parte do empreendedor, de um grupo restrito de financiadores, na sua maioria, bancos múltiplos.

Neste contexto, a dificuldade em solucionar a equação de fundos para os empreendimentos é usualmente superada partilhando-se o empreendimento em unidades menores e comercializando-as junto a investidores que buscam pagar um preço menor pelo bem,

\footnotetext{
${ }^{3}$ Utiliza-se a expressão em inglês por entendê-la como uma maneira concisa de referência ao estudo de formas de captação de recursos para um empreendimento específico, de modo a tornar o investimento mais atrativo às partes envolvidas. A filosofia empregada é a de captar recursos para a implantação e utilizar o fluxo de caixa operacional do empreendimento como contrapartida de remuneração destes recursos. Desta forma, a rentabilidade e as garantias são fornecidas pelo próprio empreendimento, devendo-se analisá-lo isoladamente do patrimônio do empreendedor.
} 
comprando-o na fase de implantação e não após a mesma. Não obstante, existem empreendimentos em que estes investidores são um único fundo de pensão. Porém, nas duas situações, o empreendedor que formata o produto participa apenas da fase de implantação, ficando a gestão do empreendimento descentralizada, e/ou sob o comando de pessoas físicas ou jurídicas que não têm conhecimento profundo do mercado no qual investem. Sendo assim, esta solução gera outro problema: a deterioração da qualidade do empreendimento, e a conseqüente quebra do desempenho esperado.

Este cenário evidencia a necessidade de estruturas mais flexíveis de captação de recursos como a securitização, que abre um novo horizonte para que os empreendedores possam tomar os recursos necessários, possibilitando o aumento do universo de investidores potenciais ao criar títulos acessíveis aos pequenos investidores, alcançando assim, uma grande massa de recursos que está pulverizada. Outro ponto importante é que, em determinados cenários de mercado, especialmente em economias estáveis, o financiamento pode representar uma alternativa menos atrativa quando comparado com a securitização, uma vez que pode implicar na geração de um custo financeiro elevado que altera o patamar de qualidade do investimento, quando comparado com o custo associado ao processo de securitização. Além disso, abre-se a possibilidade de manter o vínculo entre o empreendedor e o empreendimento durante a operação do mesmo e uma gestão centralizada e especializada, oferecendo aos investidores um grau de confiabilidade maior.

Rocha Lima (1999b) considera que a forte tradição de investimentos em produtos imobiliários e de base imobiliária verificada no mercado brasileiro, leve a discussão acerca do sistema de colocação dos títulos de securitização lastreados em empreendimentos da construção civil à concepção de um produto que não disputará com outros de caráter financeiro, mas sim com os próprios produtos imobiliários. O foco é então alargar a base de mercado, trazendo para 
produtos mais avançados de investimento os recursos que estão mal aplicados nos investimentos imobiliários tradicionais e parte dos recursos da poupança.

Rocha Lima (2001b) ressalta também que, com a capitalização dos REITs ${ }^{4}$ (Real Estate Investment Trust) americanos alcançou-se, naquele país, o grande mercado de poupanças conservadoras, com um produto de investimento ancorado no imóvel para renda e na marca de qualidade dos grandes nomes do mercado para seus respectivos REITs.

${ }^{4}$ Os REITs americanos serão tratados no item 6. 12. 


\section{OBJETIVO}

O objetivo deste trabalho é apresentar a securitização como um vetor de impulsão para o desenvolvimento de um novo ciclo do mercado de edifícios de escritórios na cidade de São Paulo, sendo capaz de atrair investidores que busquem opções de investimento para a obtenção de uma renda mensal perene $e^{5}$, com foco tanto no incremento do orçamento familiar, quanto na formação de poupança para a aposentadoria.

Desta forma, o trabalho abordará porquê e como a securitização vem a ser um vetor de investimento avançado para esta espécie de empreendimento, a ponto de garantir o volume de recursos necessários ao atendimento da demanda do mercado paulistano de edifícios de escritório, via re-direcionamento da poupança.

Para tanto, serão apresentados:

- os aspectos que fazem com que a securitização seja um elemento impulsionador, tratando assim das características estruturais do processo de securitização, apresentando uma projeção para a demanda por espaços no mercado de edifícios de escritórios em São Paulo e mostrando a atratividade dos títulos de securitização para investidores que desejam uma renda mensal perene;

- uma meta de re-direcionamento de recursos da poupança para títulos de securitização de edifícios de escritório, utilizando o benchmark $^{6}$ do mercado americano;

\footnotetext{
${ }^{5}$ Perene, no presente trabalho faz referência àquilo que dura muitos anos e não a algo que seja perpétuo, ou imperecível. Desta forma, será utilizado no texto para adjetivar a renda obtida com o investimento em empreendimentos de base imobiliária, uma vez que os mesmos apresentam longos prazos de maturação.

${ }^{6}$ Palavra inglesa que se refere àquilo que é utilizado como padrão para o julgamento, ou medida de coisas semelhantes. É neste sentido que será utilizada no texto, referindo-se ao mercado americano de securitização como exemplo a ser seguido pelo mercado brasileiro.
} 
- o significado desta meta em termos de nova oferta de espaço.

Assim, pretende-se apresentar a securitização como meio de aproximar os investidores do setor de Construção Civil e mostrar a importância da relação entre a poupança (no seu sentido mais amplo) e o setor produtivo da economia, aqui representado pelo mercado de edifícios de escritórios voltados à locação. 


\section{Estrutura do Trabalho}

No primeiro capítulo, para mostrar a importância do tema, o trabalho se inicia com a apresentação da relevância da Construção Civil para a economia brasileira. Em seguida, serão abordadas a lógica deste mercado, as características intrínsecas aos produtos nele ofertados e a complexidade dos ciclos aos quais os empreendimentos são submetidos.

O segundo capítulo trata dos edifícios de escritórios, expondo a evolução do produto e do mercado, assim como a característica cíclica deste. Em seguida, são apresentados os riscos do investimento durante o ciclo de vida do produto, assim como as fontes de recursos usuais para a implantação de edifícios de escritório. Por fim, o capítulo traz uma projeção para a recuperação dos patamares de rentabilidade setoriais para o mercado paulistano de edifícios de escritórios, com o intuito de explicitar as etapas do ciclo de mercado mais favoráveis para a sedimentação da securitização como cultura de investimento.

O terceiro capítulo introduz a securitização com lastro em ativos, apontando os aspectos relevantes e apresentando o mercado brasileiro e o americano que, por ter uma evolução maior com relação à securitização será a referência sobre a qual se traçará um paralelo para o mercado brasileiro. Este capítulo discute também o comportamento do principal investidor em empreendimentos de base imobiliária no mercado brasileiro, os fundos de pensão, a mudança da legislação que o rege e as vantagens que a securitização lhe proporciona.

O quinto capítulo apresenta simulações baseadas no comportamento de alguns tipos de investimentos, tomando como premissa que o foco do investimento é a geração de uma renda mensal perene que incremente o orçamento familiar, ou que suporte a aposentadoria do indivíduo. O objetivo é ilustrar a competitividade do investimento em edifícios comerciais, especialmente aqueles securitizados, frente às demais opções disponíveis no mercado. 
No sexto capítulo, apresenta-se um estudo sobre o re-direcionamento da poupança financeira ora abrigada na especulação do curto prazo (em virtude das altas taxas de juros) para o mercado securitizado de edifícios de escritórios. Reconhece-se que este re-direcionamento só poderá ser feito sobre os recursos conservadores o suficiente para buscar a volta ao real estate $^{7}$ como investimento conservador.

O sétimo capítulo é a conclusão da análise feita sobre os itens anteriores, mostrando que [i] o investimento em ativos securitizados é uma boa opção para o investidor e uma solução para alguns dos atuais entraves do mercado de edifícios de escritórios; [ii] a necessidade de captação de recursos do mercado e a disposição dos investidores para a remuneração proporcionada pelos títulos de securitização são aspectos convergentes; [iii] a securitização é um procedimento que, se feito de forma profissional, auxilia na evolução do mercado, na mudança de cultura de investimento e na criação e no desenvolvimento de um mercado secundário aquecido que confere sustentabilidade ao processo.

\section{1 Metodologia da pesquisa}

Inicialmente, para embasar a análise a ser feita sobre a securitização no mercado paulistano de empreendimentos de base imobiliária, mais especificamente edifícios de escritórios, será discutido o produto lastro das emissões dos títulos de securitização. Desta forma, serão tratadas as características dos empreendimentos em questão, buscando elucidar aspectos importantes que acirram ainda mais a necessidade de uma análise criteriosa e individual dos empreendimentos nos quais se estuda o investimento, exaltando os aspectos relevantes a esta tomada de decisão. O texto deixará claro que nos empreendimentos da construção civil não existe uma reposta-padrão em função do mercado, uma vez que estes empreendimentos

\footnotetext{
${ }^{7}$ Palavra de origem inglesa usada para designar o mercado imobiliário e de base imobiliária.
} 
possuem características muito peculiares. Assim, há casos em que, mesmo o mercado vivenciando um ciclo de expansão e euforia, o investimento em determinado empreendimento não é recomendado e vice-versa.

Em seguida, apresenta-se o mercado paulistano de edifícios de escritórios e a opinião de agentes de mercado e especialistas, com o objetivo de elucidar os ciclos de mercado e embasar uma projeção para o aquecimento e a conseqüente demanda por novos produtos.

Para a projeção de evolução do mercado e a identificação de sua retomada de crescimento serão feitas simulações baseadas no Produto Interno Bruto (PIB) e no preço dos aluguéis e no PIB e na absorção de estoque. Com isso pretende-se identificar a partir de quando o mercado se tornará novamente atrativo aos investidores por oferecer um retorno compatível com os riscos envolvidos. Para a arbitragem desta remuneração será utilizada a média de mercado para a qual os investidores usualmente aceitam o risco inerente a estes negócios.

Após a apresentação do produto, a securitização será conceituada com o objetivo de esclarecer ao leitor seus aspectos-chave, as vantagens que apresenta e os cuidados que são necessários para que o processo seja sustentável. Pretende-se, assim, explicitar as condições na qual esse processo surge como alternativa para o mercado da construção civil.

Para comprovar a atratividade do investimento em títulos oriundos da securitização de edifícios de escritórios, será apresentado um estudo comparativo entre diversas alternativas de investimento com foco na geração de uma renda mensal perene, já que este é o objetivo mais comum na aplicação de recursos de pessoas físicas, ou de investidores institucionais em empreendimentos de base imobiliária. Este estudo considerará o comportamento dos investimentos na última década, assim como as deduções relativas à gestão e ao imposto de renda. 
Para o estabelecimento de uma meta conservadora de crescimento da securitização de edifícios de escritórios, utilizar-se-á o paralelo do mercado americano que apresenta um grau de maturidade muito superior ao do mercado brasileiro (evidente no volume de recursos movimentados, inclusive no mercado secundário). É utilizando o mercado americano como benchmark que se pretende projetar a evolução deste mercado no Brasil, tomando a projeção de crescimento do PIB como sinalização de aquecimento do mercado de edifícios de escritório. Além disso, estuda-se o volume de recursos da poupança a serem redirecionados para a securitização em questão com o objetivo de identificar a sustentabilidade deste processo via re-direcionamento da poupança tradicional.

A seguir, com as informações do volume de recursos identificado para sustentar a securitização de edifícios de escritórios, expressa-se a equivalência destes recursos em $\mathrm{m}^{2} \mathrm{de}$ área bruta rentável (ABR) de uma região específica da cidade de São Paulo. Para embasar esta conversão, os custos de implantação serão balizados por grandes números do setor.

Por fim, os dados das duas projeções (aquecimento do mercado e re-direcionamento da poupança para a securitização) serão confrontados na busca de identificar a sustentabilidade da implantação de nova oferta de escritórios financiada pela securitização. 


\section{O MERCAdo da ConstruÇão Civil}

\section{1 Importância e peculiaridades}

O papel da construção civil no Brasil é fundamental não somente para a geração de empregos, como também pela própria natureza da atividade que alavanca uma grande cadeia produtiva, envolvendo, entre outros, os setores de cimento, metais (ferro e aço), cerâmica, madeira e produtos químicos (tintas), constituindo o que se denomina de macrocomplexo industrial da construção.

De acordo com a Pesquisa Anual da Indústria de Construção, desenvolvida pelo IBGE, a indústria da construção civil produziu 6\% da riqueza nacional em 2003; percentual que sobe para $13 \%$ quando se trata da cadeia da construção civil como um todo, o que reafirma sua importância na economia brasileira.

A construção civil tem características peculiares que a distinguem de todas as outras indústrias, seja no planejamento do produto, na decisão de investir, no prazo de implantação de seus empreendimentos, no relacionamento com seu público-alvo ou nos impactos causados pelas oscilações econômicas. Estas peculiaridades atreladas à venda, ou à exploração de seus produtos, trazem aspectos relevantes à qualidade do investimento, como será exposto neste capítulo.

Dentre estas características tem-se que: [i] o bem imobiliário possui elevado valor monetário em relação aos outros bens disponíveis no mercado e à capacidade financeira do adquirente, [ii] os empreendimentos devem ser produzidos dentro de um prazo considerado econômico, já que o aumento exagerado de seu prazo de produção implica no aumento de seus custos de implantação. A conjunção destes fatores, visando a concretização dos negócios, faz com que o 
desenvolvimento do mercado imobiliário existente em um país só seja possível com a agregação de recursos provenientes de investimentos de longo prazo.

Uma alternativa encontrada pelos empreendedores para o quadro acima descrito é a utilização de recursos próprios para o financiamento do(s) adquirente(s) de seus produtos. Entretanto, esta solução, além de desviar o foco de atuação dos empreendedores, faz com que o investimento retorne dentro de um prazo muito estendido, não compatível com a necessidade de recursos para novos investimentos, gerando hiatos na atuação dos empreendedores.

\section{2 Classificacão Básica dos Empreendimentos da Construcão Civil}

Na produção de bens do setor da Construção Civil, os empreendimentos são caracterizados pelas diferenças no teor das transações do produtor com mercado: o objetivo em determinados empreendimentos é produzir para vender, e em outros produzir para explorar uma certa atividade econômica baseada no imóvel, podendo esta se resumir meramente no seu arrendamento, como nos edifícios de escritórios, ou então, se revestir de maior complexidade, como nos shoppings centers ${ }^{8}$, hotéis ${ }^{9}$, complexos multifuncionais e até hospitais. No primeiro caso temos os empreendimentos imobiliários e no segundo os empreendimentos de base

${ }^{8}$ Os contratos de locação de shopping centers prevêem uma remuneração atrelada às vendas (percentual do faturamento da loja, independente do resultado alcançado), protegida por um mínimo conhecido como piso de locação. Ou seja, o aluguel das lojas é composto de uma parcela fixa e uma variável, sendo que os pisos devem ser definidos de forma a não pressionar o lojista demasiadamente, sob pena de gerar inadimplência e, em alguns casos, a queda da taxa de ocupação em virtude da saída de lojistas do shopping. Esta análise é essencial quando se estuda a qualidade do investimento em shopping centers, uma vez que os aluguéis são os responsáveis pelo retorno do investimento.

${ }^{9}$ Nos hotéis é usual que o empreendedor participe diretamente da operação do negócio que será implantado no local, cuja renda está diretamente ligada ao resultado da operação. Neste caso, existe a expectativa de uma renda maior do que um simples arrendamento ou aluguel, já que o investidor assume o risco da operação, o que pode converter lucro em prejuízo, caso as condições de mercado se tornem desfavoráveis à operação do hotel. 
imobiliária $^{10}$. Para esclarecer melhor o segmento que será analisado no presente trabalho, segue abaixo uma breve descrição sobre empreendimentos imobiliários e de base imobiliária.

\subsubsection{Empreendimentos Imobiliários}

Empreendimentos imobiliários são aqueles cujo objetivo final é a venda da edificação. Para descrever de forma mais clara as características deste tipo de empreendimento, duas situações hipotéticas extremas são apresentadas: a primeira trata de um ciclo puro de implantação, seguido de um ciclo puro de comercialização, ou seja, durante a implantação não se utilizam recursos oriundos da comercialização para reduzir o volume de investimento; enquanto que a segunda trata do caso oposto no qual minimiza-se o volume de investimento e garante-se o fluxo de retorno antes do início da implantação.

\subsubsection{CICLO DE IMPLANTAÇÃO SEGUIDO DE CICLO DE COMERCIALIZAÇÃO}

O longo prazo de implantação de empreendimentos imobiliários faz com que se desconheça o mercado em que se dará a competição. Ou seja, o planejamento do produto é feito com base no mercado vigente nesta fase, que sofre alterações diárias em virtude das oscilações na economia, nas taxas de desemprego etc., gerando um risco econômico intrínseco ao produto.

Além disso, como o ato de adquirir um imóvel não é cotidiano, há pouca sensibilidade dos consumidores para com o produto, seja pelo desejo de ter o melhor produto, seja pela falta de conhecimento do mercado. Sendo assim, à parte do fato da constante mutação do mercado

${ }^{10} \mathrm{Na}$ terminologia americana os empreendimentos imobiliários são denominados "residential real estate", enquanto que os de base imobiliária são "commercial real estate". 
alvo $^{11}$, as pesquisas feitas junto aos possíveis consumidores para estes produtos não geram bons resultados.

Outro aspecto relevante é a disparidade entre o binômio [qualidade x preço] no qual o consumidor gostaria de realizar a transação e aquele no qual a transação é viável, gerando, portanto, uma frustração com a qual o consumidor e o empreendedor devem se habituar. Esta disparidade foi agravada pelas oscilações econômicas, pelas crises no setor de construção civil, pela falência do SFH (Sistema Financeiro da Habitação) etc., fazendo com que os desejos de grande parte dos consumidores deixassem de ser atingidos em virtude do baixo poder de compra, e dos elevados custos atrelados ao financiamento do comprador.

Por outro lado, na hipótese de um ciclo puro de implantação, o empreendedor se protege dos desvios orçamentários desta fase, uma vez que pode marcar o preço de venda com o conhecimento do valor gasto para a sua produção. Obviamente, esta proteção não é infinita, já que os compradores encontrarão no mercado outras opções nas quais o binômio [qualidade $\mathrm{x}$ preço] estará em maior concordância com seus parâmetros de aquisição.

\subsubsection{CICLO DE COMERCIALIZAÇÃO SEGUIDO DE CICLO DE IMPLANTAÇÃO}

Neste caso, tem-se a garantia do fluxo de retorno, uma vez que a implantação ocorre após a comercialização. Além disso, esta condição faz com que o cronograma de implantação não sofra interrupções oriundas da falta de recursos em caixa, minimizando desvios orçamentários, gerando uma configuração mais estável para a taxa de retorno do investimento. A prática usual de mercado é iniciar o empreendimento pelo ciclo de

\footnotetext{
${ }^{11}$ Ressalto aqui dois aspectos distintos: [i] a aquisição do imóvel é uma decisão de caráter muito pessoal e [ii] as pessoas que hoje estão à procura de um imóvel, não o estarão daqui há 2 anos, quando o empreendimento em planejamento estará implantado.
} 
comercialização e terceirizar a implantação com o intuito de mitigar os riscos macroeconômicos, fazendo desta a melhor opção para garantir a qualidade do investimento.

\subsubsection{Empreendimentos de Base Imobiliária (EBI)}

No caso dos EBIs, tem-se o ciclo de implantação seguido do ciclo operacional no qual se promove a exploração do empreendimento, sendo que este tem prazo bastante estendido, da ordem de 20 anos (período após o qual se admite a continuidade da exploração, mediante investimentos na reciclagem do empreendimento).

Para estes empreendimentos o grande problema é o desconhecimento do comportamento do mercado durante o longo período operacional. Sendo assim, em alguns casos são necessários novos investimentos a fim de manter o empreendimento competitivo frente a possíveis alterações da demanda, ou mesmo alterar os patamares de renda em períodos de recessão.

“Outra característica importante dos EBIs é o lastro que ele carrega, pois por trás de um negócio de base imobiliária existe o lastro da operação, representado pelo valor do edifício, base do negócio ${ }^{12 ", ~(T A K A O K A ~ p .12, ~ 2003) . ~}$

Analisando-se as definições acima, o segmento de interesse para o presente trabalho é o de EBIs, que aqui serão representados por edifícios de escritórios para locação ${ }^{13}$, admitindo-se

${ }^{12}$ Cabe mencionar os negócios da Construção Civil, gerados por operações de construir, operar e transferir ao final de determinado período (BOT - Build, Operate and Transfer). Como exemplo de empreendimentos BOT podem ser citados: redes de transmissão de energia elétrica, concessões de rodovias, concessões de sistemas de telecomunicações, concessões de usinas hidrelétricas etc.

Vale observar que em nenhum destes casos o operador é dono da propriedade imobiliária, base do negócio. Estas operações são muito semelhantes às dos empreendimentos de base imobiliária, mas com uma grande diferença: elas não trazem consigo os lastros imobiliários que, no outro caso, ajudam a proteger os investidores.

${ }^{13}$ A partir deste ponto do texto, o enfoque ao tratamento dos EBIs será feito no âmbito específico dos edifícios de escritórios. Sendo assim, para facilitar a leitura e a compreensão do leitor, utiliza-se a sigla EEL para tratar de Edifício de Escritórios para Locação, permitindo ainda a utilização de EELs em referência a seu plural. 
que a geração de renda ao longo dos anos de exploração do empreendimento proporcionará o retorno dos investimentos ancorados em títulos de securitização. 


\section{O MERCADo de EdIFícios de ESCRITórios Na CIDAde de SÃo PAUlo}

\subsection{Edifícios de escritórios}

A conceituação moderna de edifícios de escritórios os reconhece como sendo o ambiente adequado ao desenvolvimento dos negócios dos seus ocupantes e parte integrante destes. Sendo assim, para que estes edifícios atendam da melhor forma os seus usuários, é necessário que acompanhem as evoluções tecnológicas, dos sistemas que constituem a base de facilidades, dos conceitos arquitetônicos, das estruturas organizacionais do trabalho, bem como os movimentos dos centros de negócio dentro da malha urbana. Esta conceituação aponta a perecibilidade da qualidade dos edifícios comerciais (VERONEZI, 2004).

Esta perecibilidade faz com que muitas empresas optem por locar espaços para o desenvolvimento de suas atividades, ao invés de imobilizar seus recursos na aquisição destes espaços, fazendo com que o dinamismo do mercado de locação de edifícios de escritórios em determinada área urbana seja maior na medida em que empresas ali alocadas, optem por ocupar edificações que têm terceiros como proprietários.

Segundo $\operatorname{NRE}^{14}$ (2002), há a tendência de concentração de empresas de serviço nas grandes regiões metropolitanas, em virtude da demanda que as atividades industriais têm por grandes espaços para o seu desenvolvimento, encontrando no elevado valor do espaço urbano, uma barreira competitiva na colocação de seus produtos no mercado. Além disso, a necessidade de interação entre os diversos agentes econômicos e a dificuldade de locomoção nos grandes centros urbanos fazem com que a demanda de mercado se apresente em áreas de concentração

\footnotetext{
${ }^{14}$ Núcleo de pesquisa e prestação de serviços à comunidade do Grupo de Gerenciamento de Empresas e Empreendimentos na Construção Civil, da Escola Politécnica da USP. O NRE desenvolve atividades orientadas à economia e aos negócios em real estate.
} 
na malha urbana. Apesar deste processo de concentração ser natural, ele pode sofrer alterações em virtude da intervenção estatal e da ação de empreendedores, ou ainda, através de ações conjuntas que envolvam parcerias da esfera pública com agentes privados ${ }^{15}$.

As ações indutoras podem ter duas origens operando isolada, ou conjuntamente:

[i] nas ações do Estado, através de diretrizes de ocupação formuladas em planos diretores e nas legislações de uso e ocupação do solo urbano; ou ainda através de incentivos tributários para atrair investimentos imobiliários, visando à recuperação de áreas urbanas deterioradas.

[ii] na ação de empreendedores pela busca de inaugurar segmentos de mercado latentes ainda não claramente percebidos como tal pela concorrência e, na medida em que alcançam sucesso na exploração dos empreendimentos, rapidamente a região se torna preferencial para novos lançamentos (NRE, 2002).

As leis, decretos e resoluções que ditam as diretrizes de zoneamento orientam o tipo de ocupação, a taxa de ocupação, os coeficientes de aproveitamento, as questões de preservação ambiental etc., e, com isso, direcionam o surgimento e a competitividade entre os pólos de edifícios de escritórios na cidade, gerando reflexos óbvios no setor tais como: redução das taxas de retorno; aumento dos valores dos novos contratos de locação e desvalorização nos preços dos terrenos. A legislação da cidade de São Paulo prega a utilização da Outorga Onerosa $^{16}$ como instrumento para a concessão de aumento de coeficiente de aproveitamento

15 As denominadas operações urbanas hoje em aplicação na cidade de São Paulo são exemplo de intervenção urbana através de parcerias público-privadas. São regulamentadas por leis municipais e compreendem um conjunto de intervenções coordenadas pela Prefeitura. A Prefeitura possibilita aumentar o potencial construtivo nas regiões influenciadas por estas intervenções. As empresas interessadas em construir mais do que o permitido pela Lei de Zoneamento nessas regiões pagam por essa permissão. Com os recursos assim arrecadados, a Prefeitura realiza melhorias na cidade. (DATABOLSA, 2002 apud Veronezi, 2004).

16 “Outorga Onerosa é a concessão, pelo Poder Público, de potencial construtivo adicional acima do resultante da aplicação do Coeficiente de Aproveitamento Básico, até o limite estabelecido pelo Coeficiente de 
de terrenos. Os coeficientes têm valores específicos para as diferentes áreas da cidade, sendo que a caracterização das mesmas é feita pela Lei de Zoneamento (Lei n ${ }^{\circ}$ 13.885/04).

Neste contexo, a Prefeitura criou o Certificado de Potencial Adicional de Construção (CEPAC) que é uma forma de "contrapartida financeira de outorga onerosa do potencial construtivo adicional, da alteração de uso e de parâmetros urbanísticos, para uso específico nas Operações Urbanas Consorciadas" (LEI N ${ }^{0}$ 13.885, de 25 de agosto de 2004). Ou seja, o CEPAC é um instrumento de securitização do direito de construir e uma fonte de recursos para viabilizar investimentos sociais e de infra-estrutura urbana.

Seja qual for o vetor de indução, o comportamento do mercado de escritórios está intimamente vinculado à dinâmica urbana, como não poderia deixar de ser, uma vez que é no tecido urbano que se desdobram as atividades no setor, o que explica a transformação de uma região considerada de prestígio em local decadente. Isto é notado nos dois mais importantes mercados de escritórios do Brasil (São Paulo e Rio de Janeiro), onde o processo de expansão gerou subcentros que passaram a "competir economicamente de forma acirrada com o centro tradicional, de modo a se tornarem ou almejarem se tornar os 'novos centros'. Isso se dá, em particular, pela lógica dessa expansão, que acarreta muitas vezes a fuga de empresas para os subcentros e a deterioração urbana do núcleo original, concomitante à mudança na composição social da população que passa a habitar este último, ligada às classes populares”. (FRÚGOLI JR. p.9, 1998 apud VERONEZI, 2004) ${ }^{17}$.

Aproveitamento Máximo, de alteração de uso e parâmetros urbanísticos, mediante pagamento de contrapartida financeira" (Lei n 13.430, de 13 de setembro de 2002).

"O valor da contrapartida financeira será depositado na conta corrente do Fundo de Desenvolvimento Urbano, instituído pelo artigo 235 da Lei no 13.430, de 2002” (Decreto n 43.232, de 22 de maio de 2003).

17 FRÚGOLI JR., H. O Centro, a avenida Paulista e a avenida Luiz Carlos Berrini na perspectiva de suas associações: centralidade urbana e exclusão social. 1998. 305p. Tese (Doutorado) - Faculdade de Filosofia, Letras e Ciências Humanas, Universidade de São Paulo. São Paulo, 1998. 
Neste contexto, o NRE (2002), identifica como fatores que pautaram o desenvolvimento do mercado de locação de espaços para escritórios nas últimas décadas, nas principais metrópoles mundiais:

[i] crescimento dos custos da compra de terrenos nas áreas mais nobres das grandes cidades.

[ii] necessidade das empresas em concentrar recursos na busca de maior produtividade e competitividade no segmento de negócios em que operam, e não na formação de ativos imobiliários,

[iii] intensa evolução tecnológica dos processos de produção e gerenciais verificados nos últimos anos e nos mais variados setores da economia. Neste sentido, Graça (informação verbal $)^{18}$ ressalta ainda a mudança na forma de trabalho com impacto na conformação dos ambientes, apontando uma queda na área dimensionada para cada indivíduo de 25 para $16 \mathrm{~m}^{2}$. $\mathrm{Ou}$ seja, posto que as necessidades de espaço vão se alterar, seja no tamanho ou na configuração, na medida em que ocorrem mudanças de ordem tecnológica ou de procedimentos de gerenciamento empresarial, a realização de pesados investimentos em espaços de escritórios próprios, especialmente naqueles cujo projeto apresenta rigidez estrutural e arquitetônica de difícil reconfiguração, mostra-se desvantajosa.

A estes fatores pode-se aglutinar outro:

[iv] aumento dos custos de construção das edificações já que o mercado demanda maior número de facilidades.

\footnotetext{
${ }^{18}$ Informação fornecida pelo Prof. Dr. Moacyr Eduardo Alves da Graça em São Paulo, em 2005.
} 


\section{2 A evolução do produto edifício de escritórios}

A evolução dos edifícios de escritórios nos últimos anos, ocorreu pautada nos seguintes aspectos (informação verbal) ${ }^{18}$, tendo como foco o aumento da competitividade e o atendimento à legislação e às novas necessidades que se apresentaram no decorrer dos anos:

- qualidade estética diferenciada, com o objetivo de agregar status e identidade às empresas usuárias;

- qualidade interna no que se refere ao ganho de produtividade propiciado pelas facilidades do edifício ${ }^{19}$

- $\quad$ segurança física e de combate à incêndio;

- custo efetivo da operação do prédio, tendo em mente que a operação adequada pode reduzir custos de readequação necessários à manutenção da competitividade do empreendimento;

- acessibilidade, mostrando a preocupação com os deficientes físicos imposta às empresas pela legislação;

- funcionalidade, no que se refere à manutenção do funcionamento dos itens necessários ao desempenho da edificação;

- operacionalidade como preservação da qualidade da edificação no que diz respeito ao atendimento das necessidades de seus ocupantes;

\footnotetext{
${ }^{19}$ Prof. Graça faz a distinção entre utilidade e facilidade, sendo que a primeira representa a infra-estrutura local, enquanto a segunda representa a própria edificação, juntamente com os serviços prestados em favor do desenvolvimento dos negócios dos usuários da edificação (limpeza, segurança etc.).
} 
- $\quad$ sustentabilidade, mostrando a preocupação com o meio-ambiente no que diz respeito a recursos hídricos e energéticos. Neste aspecto a crise energética brasileira fez com que essa preocupação se acentuasse, uma vez que afetou o cotidiano das empresas, trazendo para o presente uma preocupação que parecia futurista para alguns.

Todos os atributos dos EELs têm relação direta com as necessidades do potencial ocupante para o desenvolvimento de suas operações cotidianas, que por sua vez, tem correlação com o elo que ocupa na cadeia produtiva do setor econômico em que se insere.

Uma característica importante dos EELs, que impacta na formatação e na gestão do empreendimento, é a elevada rigidez do produto, de modo que a possibilidade de reconfigurações nos atributos físicos e na infra-estrutura de facilidades com o intuito de reposicionar o empreendimento na fronteira de mercado, quando não é nula, exigirá intensos investimentos que produzirão quebras na sua qualidade do ponto de vista econômico, segundo a visão original.

Algumas evoluções tecnológicas, como a dos sistemas de ventilação e ar condicionado, e algumas restrições, como a crise energética brasileira do início do século XXI que questiona a sustentabilidade dos EELs, provocam alterações importantes na formatação dos EELs, questionando a flexibilidade dos edifícios para o atendimento das novas demandas. Desta forma, a formatação de EELs está baseada em um tripé: [i] capacidade de pagar das empresas, [ii] servibilidade ${ }^{20}$ do edifício e [iii] peso dado à imagem e ao status que edifícios mais modernos imprimem no público.

\footnotetext{
${ }^{20}$ Servibilidade é a maneira pela qual o edifício atende os propósitos de seus usuários. (informação verbal
} fornecida pelo Prof. Dr. Moacyr Eduardo Alves da Graça em São Paulo, em 2005) 
Para que os EELs mantenham a inserção de mercado e garantam seu potencial de geração de renda frente às evoluções que se apresentam no mercado em que operam, é importante que sua servibilidade seja garantida pela gestão adequada de suas utilidades e facilidades.

Antonioli; Graça (2004) definem o gerenciamento de facilidades como sendo a integração de pessoas, espaço e tecnologia através do gerenciamento dos processos de inter relacionamento destes sistemas, visando à satisfação dos objetivos corporativos da organização que os contêm. Ou seja, o gerenciamento das facilidades de uma edificação é o processo pelo qual um complexo empresarial assegura que suas instalações, sistemas prediais e serviços de apoio suportem total e efetivamente a atividade-fim, contribuindo, significativamente, para que os objetivos estratégicos sejam alcançados. Estes serviços são: alimentação, limpeza, segurança, manutenção e modernização dos computadores, processamento de dados, abastecimento de água, luz, etc. Normalmente, os grandes empreendedores criam uma empresa de gestão dedicada a seus empreendimentos, com o objetivo de assegurar a qualidade e o desempenho de seus produtos e, com isso, garantir sua competitividade no mercado (informação verbal) ${ }^{18}$.

Quando o empreendimento tem suas unidades comercializadas independentemente, prática usual de mercado com o objetivo de atrair investidores, a dificuldade em se manter uma gestão centralizada e especializada pode comprometer a inserção de mercado do EEL e, consequientemente, a qualidade do investimento nele lastreado.

\section{3 Classificacão dos edifícios de escritórios}

Com o intuito de identificar os movimentos de mercado que serão tratados adiante, descrevese a seguir uma classificação básica para os EELs. Caso o leitor tenha interesse em se aprofundar no assunto, recomenda-se a leitura de Veronezi (2004). 
A rigidez estrutural dos EELs faz com que a segmentação no mercado de escritórios comerciais ocorra a partir dos atributos físicos e de facilidades presentes na edificação e das condições de infra-estrutura urbana no seu entorno. Sendo assim, a segmentação do mercado de edifícios de escritórios se dá nos seguintes aspectos:

- distribuição espacial: "as regiões munidas de melhor infra-estrutura urbana favorecem o surgimento de pólos do setor terciário, gerando demanda por edifícios adequados ao desenvolvimento dessas atividades. Quantidade e qualidade de transporte público e de vias de acesso, redes de abastecimento de energia e de água, sistema de coleta e tratamento e esgoto, sistema de comunicação, serviços complementares e conexão com sistemas financeiros são exemplos de atrativos que historicamente têm contribuído para formação de pólos de serviços" (VERONEZI p. 13, 2004),

- público potencial que se pretende atender. "Uma vez que o prédio de escritórios é entendido como ambiente adequado para desenvolvimento de negócios e como parte integrante destes, ele deve acompanhar as evoluções tecnológicas, arquitetônicas, organizacionais do trabalho e os movimentos dos centros de negócios dentro da malha urbana, para que possa atender da melhor forma seus ocupantes" (VERONEZI p. 14, 2004),

- localização, “além da atratividade da região (zona em ascensão, neutra ou decadente ${ }^{21}$ ), são valorizados também aspectos como: vizinhança, disponibilidade de diversos serviços

\footnotetext{
${ }^{21}$ zona em ascensão: melhoria e/ou aumento da infra-estrutura instalada na região. Isso favorece o surgimento de pólos do setor terciário, gerando demanda por edifícios adequados ao desenvolvimento dessas atividades e aumentando o prestígio da região;
}

zona neutra: suficiência - sem expectativa de crescimento nem de melhoria da infra-estrutura instalada na região. Isso mantém os edifícios de escritórios já instalados na região, porém não atrai novos desses empreendimentos, perdendo em competitividade para as zonas julgadas como ascendentes; 
no entorno do edifício (bancos, alimentação, shopping centers, correio, cartório, etc.), facilidade de acesso, entre outros" (VERONEZI p. 15, 2004).

No mercado, não há uma classificação padrão, fazendo com que os agentes de mercado mantenham classificações próprias com o intuito de estratificar o mercado e analisar suas tendências. De forma geral, os empreendimentos de escritórios são classificados como edifícios classe A, B ou C de acordo com os indicadores que caracterizam sua formatação, como mencionado nos parágrafos anteriores. Porém, nestas categorias ainda existem outras subdivisões que variam de agente para agente ${ }^{22}$.

Em linhas gerais, "os entendidos como classe A são aqueles que incorporam em seu projeto uma extensa gama de sistemas prediais de alta tecnologia, padrão de acabamento de primeira linha, número de vagas por $\mathrm{m}^{2}$ de área útil compatível com padrões internacionais e um patamar mínimo de serviços internos disponíveis.

Em geral, no Brasil, empreendimentos com estas características têm como público alvo para ocupação, grandes companhias multinacionais. As demais classes, B e C, englobam como público alvo para ocupação não só grandes companhias, mas empresas prestadoras de serviços de pequeno porte e profissionais liberais" (NRE p.10, 2002).

Como um organismo independente no mercado brasileiro de edifícios de escritórios, o NRE analisa e classifica estes edifícios, segundo critérios para análise da qualidade dos mesmos. Os

zona decadente: insuficiência - sem expectativa de crescimento nem de melhoria da infra-estrutura instalada na região. Essa situação pode ser decorrente ou da falta de espaço físico para que sejam feitos investimentos em melhorias da região (abertura de vias de acesso, disponibilidade de terrenos incorporáveis, etc.) ou de falta de recursos públicos para tais fins. Isso acarreta, muitas vezes, a fuga de empresas para as regiões ascendentes e a deterioração urbana da região original, cujo prestígio esvai-se.

22 Muitos dos agentes que operam no mercado brasileiro são multinacionais que trazem para matriz de classificação dos edifícios o viés de seus mercados de origem, ou mantém uma matriz de classificação global para a consolidação de dados mundiais, o que torna a classificação menos precisa, uma vez que não há foco nas necessidades do mercado em que o empreendimento está inserido. 
fundamentos desta classificação e suas categorias podem ser encontrados no endereço eletrônico da instituição ${ }^{23}$.

\section{4 A evolucão do mercado de edifícios de escritórios na cidade de São Paulo}

Neste item será feito um breve histórico do mercado paulistano de edifícios de escritórios, embasado em um relatório do NRE (2002), mostrando ao leitor a dinâmica deste mercado e os fatores que impulsionam suas mudanças de rota.

No Brasil, a região metropolitana da cidade de São Paulo é sabidamente a área de maior dinamismo econômico, principalmente no que diz respeito às atividades de serviços. Por conseguinte, é nesta região que se apresenta o mais dinâmico mercado de escritórios para locação do Brasil, tanto no que se refere às massas de construção, lançadas e absorvidas no mercado, quanto ao padrão tecnológico incorporado nos empreendimentos. Este mercado teve início no desenvolvimento da região central.

Na década de 30, em São Paulo, a região central foi a primeira a dispor de infra-estrutura e de serviços urbanos, por isso ainda concentra grande parte do estoque dos edifícios comerciais composto por edificações antigas, com pouca infra-estrutura de facilidades, sem ou com poucas vagas de garagens e sem ar-condicionado central.

Em meados dos anos 50, o centro começou a mostrar sinais de saturação, levando o mercado de escritórios a mover-se em direção à Zona Sul, seguindo outros movimentos de atividades econômicas na cidade. É assim que a Avenida Paulista, ao sul do centro, começou a surgir como novo pólo de escritórios e teve grande desenvolvimento durante os anos do milagre econômico brasileiro, até que nos anos 70, esta região começou a mostrar sinais de saturação,

\footnotetext{
${ }^{23}$ Vide lista de referências.
} 
com trânsito congestionado na sua vizinhança. Iniciou-se, então, o desenvolvimento de novas regiões novamente em direção à Zona Sul, principalmente na Faria Lima e na Marginal Pinheiros.

Os primeiros edifícios comerciais, ao longo das margens do Rio Pinheiros, surgem no final dos anos 70, onde intensifica-se a oferta de edifícios comerciais a partir da década de 80, originando as atuais regiões conhecidas como, Vila Olímpia, Berrini e Marginal.

A partir de 1996, o prolongamento da Avenida Faria Lima possibilitou do uso de vários novos terrenos com potencial para o desenvolvimento de empreendimentos. Os novos projetos em fase de implantação e/ou lançamento, que incorporam aos edifícios atributos de qualidade e flexibilidade mais contemporâneos, irão alterar o perfil da região que conta hoje com estoque composto por conjuntos pequenos, com infra-estrutura de facilidades e estacionamentos inadequados.

Resumindo, o mercado de escritórios na cidade de São Paulo se desenvolveu a partir da consolidação de áreas comerciais pulverizadas em zonas da cidade, principalmente as zonas centrais e sul. Desse modo, os principais mercados de escritórios regionalmente consolidados na cidade de São Paulo são: Centro (Distrito Comercial Central), Avenida Paulista, Avenida Faria Lima, Bairro dos Jardins, Bairro do Itaim, Bairro da Vila Olímpia, Avenida Luís Carlos Berrini, Marginal Pinheiros e no Bairro da Chácara Santo Antônio.

Atualmente, encontra-se em fase de implantação uma nova oferta de edifícios comerciais, juntamente com o padrão de oferta recentemente lançado, configurará o estoque de escritórios mais modernos no Brasil. Mesmo assim, o maior número de lançamentos tem sido de edifícios cuja infra-estrutura de facilidades é considerada como de médio padrão, tendência que deve permanecer, pois estes edifícios são capazes de se acomodar melhor, via ajustes de preços, às necessidades de um espectro mais heterogêneo de usuários. 
“O mercado de edifícios de escritórios de alto padrão na cidade de São Paulo encontra-se numa conjuntura recessiva desde o ano de 2.000. A recuperação da atividade no setor está vinculada, num nível intrínseco, à retomada do crescimento econômico e da expansão da atividade na área metropolitana de São Paulo. De outro lado, a expansão no setor de escritórios comerciais em São Paulo está associada ao posicionamento dos empreendedores com relação às expectativas de ocupação do estoque ativo ainda ocioso e de composição do binômio [risco x retorno] potencial de novos empreendimentos nos próximos anos" (ROCHA LIMA; ALENCAR p.1, 2004).

A afirmação acima é sustentada por publicações feitas por agentes do mercado como as da empresa Jones Lang LaSalle ${ }^{24}$, que publicou em seu balanço de 2002 que o processo de desaceleração da demanda por edifícios de escritórios continuou em 2002, confirmando a tendência apresentada a partir de 2001, ressaltando que a instabilidade econômica, causada pela percepção dos mercados com relação à transição política entre os governos de Fernando Henrique Cardoso e Luís Inácio Lula da Silva, aguçou a crise e colaborou para a retração da demanda, uma vez que nesses cenários as corporações internacionais normalmente se mostram mais cautelosas para investir em mercados estrangeiros, especialmente nos emergentes como é o caso do Brasil.

Segundo a Jones Lang LaSalle (2002), o visível desequilíbrio entre oferta e demanda na cidade, ocasionou a postergação de cerca de $30 \%$ dos projetos de classe AA previstos para serem entregues em 2002 e o adiamento de diversos lançamentos de outras categorias, além de uma queda média de $11 \%$ nos valores de locação dos edifícios classe AA e A em relação ao mesmo período do ano passado. A expectativa era de recuperação lenta da demanda em 
2003, com a tendência de crescimento das taxas de vacância para edifícios de alto padrão principalmente nas regiões Faria Lima e Berrini, em virtude da entrada de novo estoque.

Os gráficos a seguir mostram a evolução de alguns indicadores de mercado mais utilizados no meio, mas antes de analisá-los, segue uma descrição sucinta dos indicadores apresentados.

\subsubsection{Indicadores de mercado e sua evolucão}

Para analisar a evolução do mercado, os agentes fazem uso de indicadores que, por se embasarem em dados pulverizados e metodologias simplistas de extração, nem sempre são capazes de representar um estrato específico do mercado. Neste sentido, o desalinhamento das classificações de EELs é outro fator que interfere na acuidade dos indicares.

\subsubsection{NOVO ESTOQUE}

Novo estoque nada mais é do que o volume de $\mathrm{m}^{2}$ úteis de escritório que foi entregue no mercado no período em curso ou que ainda vai ser entregue (JONES LANG LASALLE, 2002).

\subsubsection{ABSORÇÃO LÍQUIDA}

É a diferença entre as áreas efetivamente locadas em dois períodos consecutivos, que permite identificar a dimensão da demanda de mercado e também a percepção da freqüência de reposicionamento da demanda relativamente à oferta (NRE, 2002).

Além da absorção líquida, existem outros indicadores de absorção com foco na identificação do dimensionamento da demanda frente à oferta existente, tais como: taxa de absorção do

\footnotetext{
${ }^{24}$ Empresa com forte posicionamento mundial em consultoria imobiliária e gerenciamento de investimentos. Para tanto, mantém uma área de pesquisa exclusiva responsável pelo acompanhamento e a interpretação do
} 
estoque, taxa de absorção do estoque novo, absorção absoluta. As taxas de absorção são o quociente entre o espaço efetivamente locado e o espaço ofertado num dado período, enquanto que a absorção absoluta computa a área de escritórios efetivamente locada num dado período.

Segundo o NRE (2002), altas taxas de absorção denotam o aquecimento do mercado e a adequação dos diversos estratos de oferta com relação às distintas necessidades da demanda. Já a absorção absoluta de espaços para locação comercial num dado período tem, inequivocamente, correlação direta com o comportamento da atividade econômica no âmbito da região urbana, que por seu turno, deverá manter alguma correlação com a economia nacional. Ou seja, em existindo oferta qualificada disponível, de acordo com as condições estruturais e com o atual estágio de evolução alcançado no ambiente empresarial, a expansão da atividade econômica urbana local provocará intensificação da absorção de espaços para locação nos edifícios comerciais.

\subsubsection{TAXA DE VACÂNCIA}

A taxa de vacância num mercado ou segmento indica a porcentagem de área útil vaga, disponível para locação ou sub-locação, calculada em relação ao estoque total ${ }^{25}$ do mercado, ou segmento, num determinado período. Desta forma, trata-se de um indicador da relação entre oferta e demanda de espaços para escritórios, num dado período, induzindo ou inibindo as decisões de investimento ${ }^{26}$ na expansão do estoque de áreas para locação comercial. A

mercado e das tendências da economia que afetam o setor imobiliário.

${ }^{25}$ Total das áreas de escritório efetivamente construídas, e que se encontrem locadas ou disponíveis para locação em um mercado, ou segmento.

${ }^{26}$ É importante salientar que o indicador taxa de vacância apresenta deficiências congênitas enquanto expressão de desempenho econômico de um empreendimento ou mercado em particular, pois, sempre poderão ocorrer baixas taxas de vacância num segmento às expensas de valores de locação em tal medida baixos, que não seja possível, remunerar adequadamente os investimentos realizados. 
análise histórica da taxa de vacância, permite fazer inferências relativas ao posicionamento do mercado no ciclo setorial e estabelecer prognósticos envolvendo tendências de excesso de oferta no mercado ${ }^{27}$ (NRE, 2002).

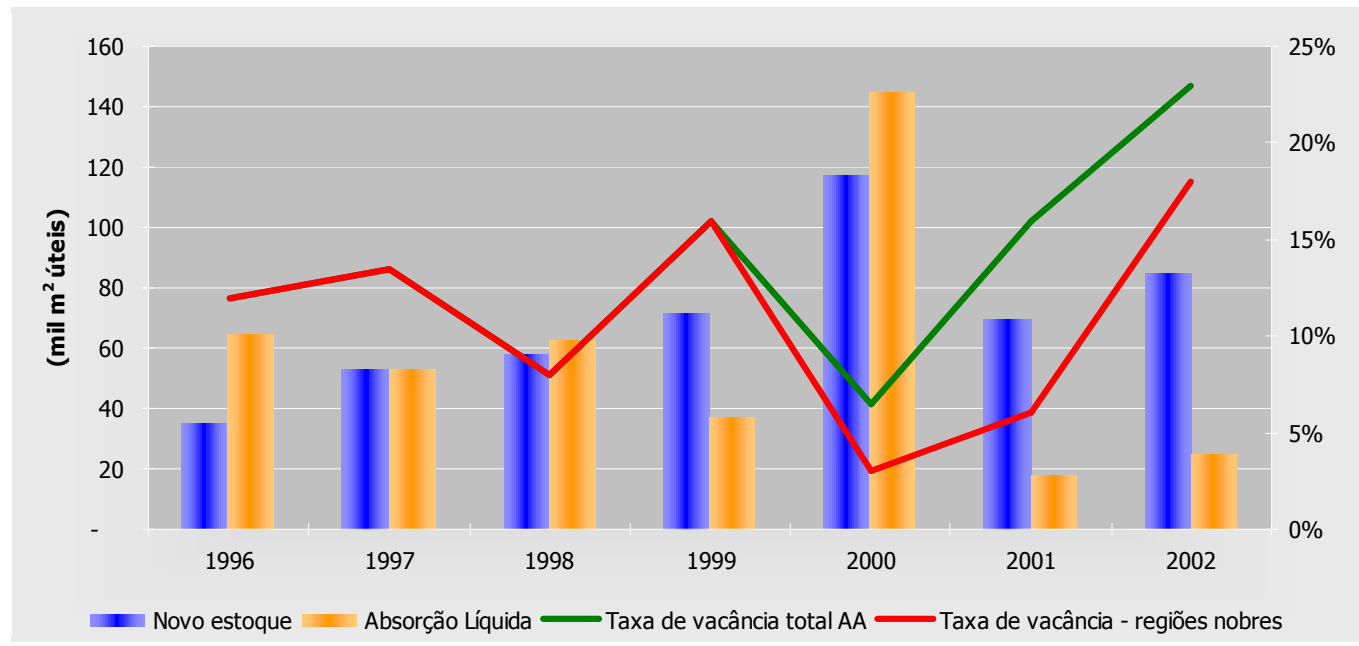

Figura 1 - Evolução de indicadores de mercado de edifícios de altíssimo padrão em São Paulo - classe AA (fonte: Jones Lang LaSalle - Balanço de 2002)

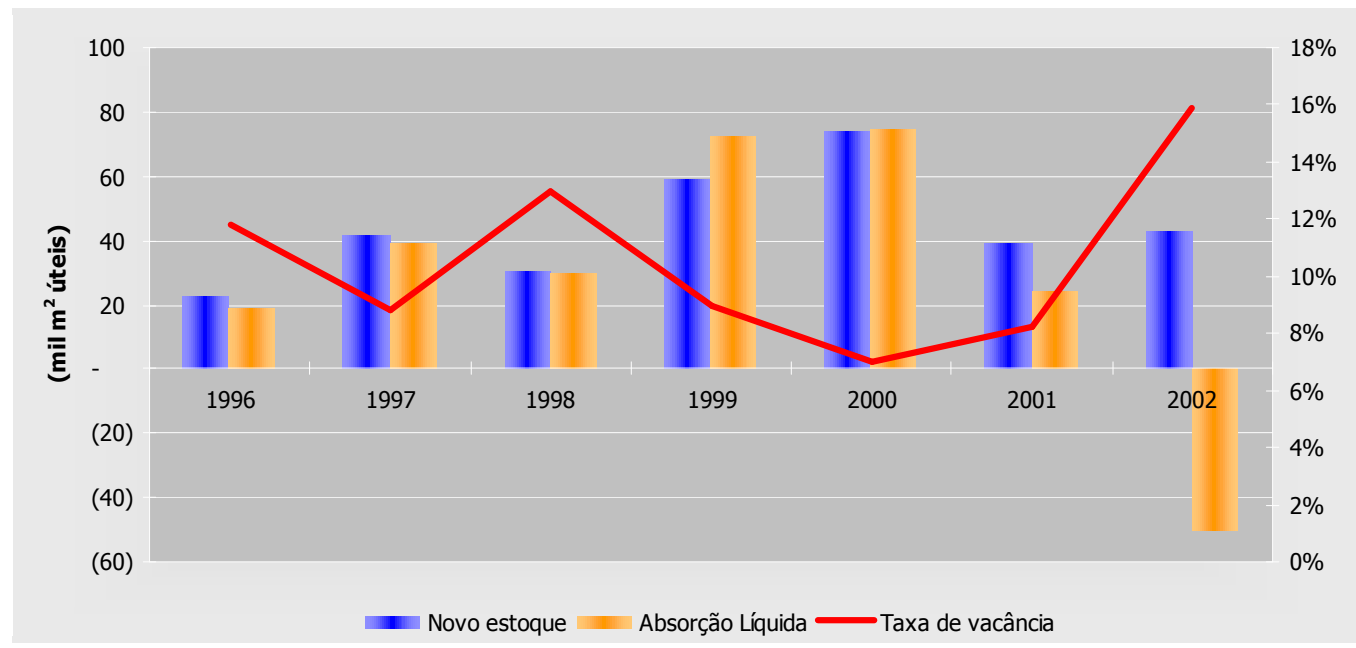

Figura 2 - Evolução de indicadores de mercado de edifícios de alto padrão em São Paulo - classe A (fonte: Jones Lang LaSalle - Balanço de 2002)

${ }^{27} \mathrm{Na}$ realidade essa análise das tendências de overbuilding requer a construção de outros indicadores que considerem as correlações entre o comportamento da atividade econômica, seja no nível local seja no nacional, e o uso do estoque consolidado de escritórios comerciais para que se estime o uso do estoque novo que estará instalado num certo prazo e, conforme o valor destes indicadores estiver posicionado, se associará uma certa condição de risco de overbuilding no mercado. 
Na Figura 1 e na Figura 2 acima observa-se que a partir de 2000, o mercado apresenta índices crescentes de desocupação apontando realmente para um período recessivo.

Restringindo-se a análise aos edifícios de classe A, observa-se que, nos últimos anos, as taxas de vacância tem alcançado patamares inferiores aos dos edifícios de classe AA.

Segundo NRE (2002), esta tendência pode ser explicada pelo fato de que edifícios de elevado padrão tecnológicos têm um público muito específico limitado especialmente pelo poder de pagar pelos atrativos oferecidos pelo produto. É claro que se o cenário recessivo perdurar por períodos longos, o mercado é pressionado a reduzir os preços de locação e esta configuração pode ser alterada. Por outro lado, há de se ressaltar que a evolução do mercado é pautada basicamente na migração dos usuários para espaços mais bem conformados, principalmente no que diz respeito à tecnologia e à base de facilidades, sejam estas as instaladas na edificação ou as disponíveis na vizinhança, em detrimento da oferta de certo modo obsoleta a despeito dos preços de locação inferiores. Isso ocorre porque para muitas das atividades desenvolvidas em edifícios de escritórios as facilidades acabam aumentando a produtividade e assim a competitividade das empresas instaladas.

"Desde a crise de energia de 2001 sucessivos cenários de incertezas frente à economia e à política interna e externa têm impedido o crescimento da demanda por edifícios de alto padrão na cidade de São Paulo. No ano de 2002 essa tendência se confirmou, visto o comportamento dos números. Os valores de locação apresentaram queda voltando a patamares de dois anos atrás e a absorção líquida - termômetro da demanda - além de registrar os números mais baixos desde o Plano Real, pela primeira vez apresentou valores negativos. O desempenho de 2002 se deu ainda em função do alto volume de escritórios que a cidade recebeu, segundo maior recebido desde de 2000. A conjunção desses fatores resultou na duplicação da taxa de vacância para edifícios classe AA e A no último ano e o adiamento de diversos lançamentos... 
A expectativa é que o volume de novo estoque entregue diminua a partir de então, iniciando o processo de ajuste do estoque frente à demanda" (JONES LANG LASALLE p. 4, 2002).

\section{5 A Complexidade dos Ciclos dos EELs}

Wheaton (1987) faz uma análise do mercado de edifícios de escritórios em algumas cidades dos Estados Unidos e conclui que é possível identificar ciclos de mercado tanto no âmbito nacional como no regional. $\mathrm{O}$ autor identifica ciclos recorrentes em períodos que variam entre 10 e 12 anos e cria um modelo pelo qual simula condições de mercado futuras. Este modelo é embasado em algumas variáveis que o autor reconhece como essenciais: [i] construções, baseado no número de licenças de construção; [ii] quantidade de obras concluídas, uma vez que há uma defasagem de tempo considerável entre a licença e a conclusão da obra (em torno de 18 a 24 meses); [iii] taxa de emprego no setor de serviços, uma vez que aproximadamente 75\% do espaço em edifícios comerciais em áreas urbanas é ocupado por empresas de serviços; [iv] taxa absorção do estoque; [v] taxa de vacância.

Wheaton (1987) ressalta a diferença básica entre o mercado mobiliário e o de base imobiliária (neste caso, especificamente edifícios de escritórios) quando aponta que o segundo trabalha com contratos de locação de longo prazo. Este diferencial do mercado reflete em custos elevados de mudanças e relocação dos negócios na malha urbana, fazendo com que estas alterações ocorram normalmente na renovação dos contratos. Ou seja, quando uma empresa necessita ampliar seus espaços ela inicialmente tenta fazê-lo através da reestruturação do local em que se encontra, apelando em segunda instância para a locação de espaços não contíguos e posteriormente para o reagrupamento das atividades em um espaço maior e contíguo. De 
forma análoga, uma empresa decadente inicialmente mantém espaço em excesso, subloca-o ${ }^{28}$ posteriormente e, finalmente, na renovação do contrato, muda-se para um local menor. Desta forma, o simples fato do mercado operar com contratos de longo prazo impõe aos locatários um planejamento cuidadoso na seleção do espaço a ser ocupado. Neste balanço as expectativas sobre o crescimento da economia e as condições do mercado de escritórios, adicionadas aos níveis de aluguéis no presente podem direcionar as empresas a locar espaços menores ou maiores do que sua necessidade imediata.

Os longos ciclos de mercado podem ser reforçados pela postura dos locadores e em última instância dos empreendedores, que constroem expectativas acerca de condições futuras que influenciam os contratos de aluguel ${ }^{29}$. Desta forma, em um mercado aquecido, locadores buscarão contratos de longo prazo, sendo que em mercados em crescimento podem até criar uma demanda especulativa para a vacância. Por outro lado, em mercados desaquecidos, os locadores podem relutar em assinar contratos de prazo longo, pois vislumbram um reaquecimento, o que não acontece em mercados decadentes onde os proprietários podem tentar ocupar o imóvel, mesmo que o valor do aluguel não lhes traga ganhos. Toda essa complexidade dos compromissos assumidos entre locadores e locatários faz com que os aluguéis não se ajustem instantaneamente às condições do mercado presente.

Em suma, apesar dos ciclos do setor EELs serem correlacionados com o comportamento macroeconômico, há uma defasagem daquele em relação à evolução do ciclo econômico principal. Um dos motivos desta defasagem são os longos prazos de implantação dos

\footnotetext{
${ }^{28}$ Apesar da sublocação ser usual nos Estados Unidos, ela corresponde a um menos de $10 \%$ do estoque. Sendo assim gera distorções desprezíveis nos dados utilizados pelo autor, uma vez que o mesmo se propõe a uma análise estrutural do mercado.

${ }^{29}$ Os empreendedores consideram também a lucratividade que pretendem alcançar em um novo empreendimento e o custo de capital, seja baseado no custo de oportunidade, na taxa de juros de um financiamento, nos custos
} 
empreendimentos, fazendo com que a decisão de empreender seja tomada em uma conjuntura diferente daquela na qual o empreendimento operará. O NRE (2002) ressalta ainda outro aspecto que colabora para esta defasagem: o tempo necessário para a decisão de retomada de investimentos setoriais, que decorre dos processos de planejamento, da sedimentação da percepção individual do empreendedor, da formulação de expectativas de evolução da conjuntura econômica, para o médio e longo prazo, e seus potenciais impactos no desempenho de mercado.

O NRE (2002), tomando como referência uma certa estabilidade conjuntural, macroeconômica e de mercado, considera duas hipóteses extremas: a primeira supõe que os agentes do setor percebam a conjuntura e, formulem a expectativa de evolução com viés agressivo. O que, em um primeiro momento, pode levar a um aquecimento saudável da atividade setorial, mas que, no médio prazo poderá resultar em superoferta, inclusive com o ciclo macroeconômico já em fase de estabilização, ou mesmo em declínio, variando de acordo com a amplitude dos ciclos. Neste caso, a inserção da oferta estocada somente será efetivada quando da retomada da demanda no setor caracterizando um novo ciclo de expansão.

Já na segunda hipótese, ainda considerando a mesma referência de estabilidade, a percepção conservadora para a evolução desta conjuntura e para o desempenho médio nos mercados de real estate, propiciará a antecipação da curva de retração da atividade no segmento (por falta de produto) em relação ao ciclo macroeconômico, resultando na ampliação da defasagem entre as curvas.

de uma securitização etc. Além disso, os empreendedores embasarão sua decisão no volume do estoque e da demanda. 
Santovito (2004) cita em seu trabalho uma série de autores que em seus estudos de real estate depararam-se com a constatação de ciclos de mercado, levantando os fatores considerados como de influência nas oscilações entre os ciclos de mercado, a saber:

- comportamento macroeconômico - o desempenho da economia provoca o aquecimento, ou a retração do mercado de EELs, já que é para atender às atividades econômicas que os espaços são ocupados. Deve-se atentar para o fato de que alguns segmentos da economia não geram demanda expressiva por espaços em EELs (como o setor industrial, por exemplo), portanto, caso estes setores encabecem o crescimento econômico em determinado momento, é de se esperar que o reflexo de tal crescimento não seja imediato no mercado de EEL, sendo necessária a intermediação de outro setor responsável pela demanda de EELs;

- níveis de emprego - em teoria, quanto maior o volume de empregados, especialmente no setor de serviços, maior é a demanda por espaços de escritórios. Cabe salientar que mudanças na forma de trabalho, ou na gestão de recursos, podem provocar alterações na análise desta variável, já que haverá alteração do perfil da demanda por espaço em EELs, como por exemplo, a diminuição da área média ocupada por cada indivíduo;

- taxas de juros reais - quanto maiores são as taxas de juros reais, maior é o ônus financeiro da capitalização dos empreendedores, provocando impacto nos níveis de construção e nos aluguéis. Vale lembrar que, em se admitindo formas mais avançadas de captação de recursos, como é o caso da securitização, esta relação pode sofrer flutuações.

Pode-se notar, portanto que, apesar de existirem fatores influenciadores dos ciclos de EELs, a relação entre eles e os EELs é heterogênea ao longo das décadas, conforme o quadro geral e o contexto no qual estão inseridos sofram mutações. Assim sendo, a análise destes ciclos deve 
ser feita de forma sistêmica, de forma a detectar as razões das alterações de comportamento do mercado.

Além disso, o estudo do comportamento cíclico de mercado não deve ter a pretensão de tecer previsões, mas apenas de sustentar expectativas racionais ao desenvolvimento do mercado, o que, segundo Wheaton $(1997)^{30}$ apud Santovito (2004), poderia contribuir para a redução da amplitude das oscilações de mercado.

\subsubsection{Os quadrantes dos ciclos de comportamento dos EELs}

Segundo Rocha Lima; Alencar (2004a), conceitualmente, os ciclos de EELs envolvem os quadrantes da Figura 3, caracterizados a partir dos preços médios de locação praticados e das taxas de ocupação no mercado, relativamente a referenciais de comportamento histórico.

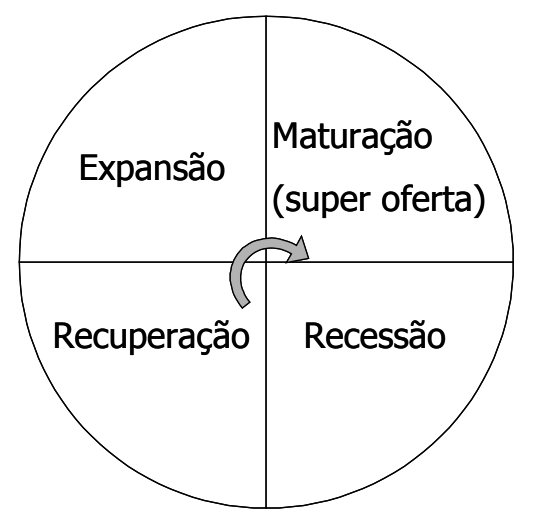

Figura 3 - Etapas presentes nos ciclos de evolução do mercado de EELs.

O quadrante de Recessão, como o próprio nome diz, apresenta baixas taxas de ocupação e preços de aluguéis abaixo da média histórica, levando a remuneração a taxas aquém da atratividade setorial.

\footnotetext{
${ }^{30}$ WHEATON, W.C. Real Estate Cycles: Some Fundamentals. MIT/CRE Working Paper n. 71, 20 p. 1997.
} 
Na transição entre o quadrante de Recessão para o de Recuperação, os preços dos aluguéis mantém-se abaixo do patamar de atratividade setorial, mas o aumento das taxas de ocupação sinaliza o reaquecimento do mercado.

No quadrante de Recuperação, o comportamento do mercado caminha para o da média histórica. As taxas de ocupação estão estabilizadas, os preços de locação retomam o crescimento e a remuneração média dos investidores situa-se entre o custo de oportunidade e a taxa de atratividade setorial.

Na transição deste quadrante para o de Expansão, a recuperação dos preços de locação até o patamar da média histórica eleva a remuneração dos investidores ao patamar de atratividade setorial.

No quadrante de Expansão, a manutenção dos preços de locação alcançados na transição anterior e os incrementos sucessivos na taxa de ocupação fazem com que o mercado atinja o ponto de máxima remuneração, elevando a média acima do patamar de atratividade setorial. É a percepção deste aquecimento que leva o mercado à condição de oferta acima da demanda, provocando o desaquecimento do mercado, característico do quadrante de Maturação (ou Super oferta).

\section{6 Riscos do investimento nas diferentes etapas do ciclo de vida do EEL}

Para a tomada de decisão de investimento em EELs, é usual que se apresentem diversos indicadores de sua qualidade extraídos de manipulações em modelos, dentro de processos de simulação em que as expectativas de desempenho dos empreendimentos são estabelecidas a partir de expectativas de comportamento presentes em cenários arbitrados no planejamento.

Assim sendo, a decisão de investimento apoiada nestes indicadores não se sustenta em certezas, já que é tomada dentro de cenários caracterizados por expectativas e estimativas, 
tendo assim, um grau de incerteza associado. Desta forma, deve-se tomar a decisão de investimento com base na probabilidade de ocorrência de eventos associados às fontes de incerteza.

Portanto, uma análise consistente, deve considerar, além dos vários indicadores, os objetivos do investidor na aplicação de seus recursos, e os riscos envolvidos no investimento, sem os quais não há como compreender os indicadores da qualidade, porque estes são estabelecidos assumindo-se como hipótese um estado de aderência entre realidade e cenário que raramente ocorre. Os impactos dos distúrbios do cenário referencial nos indicadores da qualidade devem ser discutidos na análise de riscos.

Vale salientar que o objetivo de empreendimentos de base imobiliária é a geração de renda pela exploração de suas áreas. Sendo assim, é intuitivo afirmar que a qualidade do empreendimento e, conseqüentemente, do investimento nele perpetrado está no potencial de geração de renda e não na edificação propriamente dita, sendo falsa a imagem tradicional de que o fator de segurança está na existência do imóvel, cujo valor de mercado tende a ter baixa flutuação em ciclos curtos.

Em EELs tem-se riscos distintos ao longo do ciclo de vida do empreendimento. Desta forma, os modelos nos quais simulam-se os indicadores de qualidade devem permitir um tratamento diferenciado de cada etapa, de modo a possibilitar uma melhor modelagem.

Para levantar os riscos inerentes a um EEL, divide-se o seu ciclo de vida em:

- ciclo de implantação, que retrata o período de construção da edificação na qual determinada atividade econômica será desenvolvida; 
- ciclo de operação. É neste ciclo que se promove a exploração da edificação através da locação de suas áreas a pessoas físicas, ou jurídicas que desenvolvam ali alguma atividade econômica.

Durante a fase de implantação de um EEL, muitas são as incertezas no cenário admitido como válido quando da formatação do empreendimento. Neste período os principais riscos são:

- desvios de orçamento da implantação,

- perturbações na inserção de mercado.

Para mitigar os desvios orçamentários na implantação pode-se contratar a preço fechado empresa especializada para a construção da edificação. Já, o risco de perturbações na inserção de mercado tem raízes nas alterações de cenário que podem ocorrer entre a formatação e o início da operação do empreendimento. Para mitigá-lo, deve-se ter um profundo conhecimento do mercado para identificar o ciclo pelo qual o mesmo está passando, e o padrão da demanda que se delineia para a época do início da operação do empreendimento. Outra possibilidade é implantar empreendimentos built to suit $^{31}$ atrelados a contratos semelhantes aos de locação, mas que forcem o pretenso locatário a manter os pagamentos dos aluguéis por longos prazos, inibindo uma possível rescisão a prejuízo do empreendedor. A idéia é que empreendimentos formatados sob medida não são facilmente locados a outros usuários, exigindo um esforço de reciclagem para atrair novos locatários, cabendo, portanto, a aplicação de mecanismos de proteção do empreendedor.

31 Edifícios built to suit são aqueles construídos para um determinado locatário, visando atender a suas necessidades específicas. Desta forma, o locatário dita as especificações da construção e em troca assume o compromisso de um arrendamento de longo prazo. 
No ciclo de operação, a inserção de mercado já é conhecida, ou pode ser estimada de maneira mais precisa, uma vez que o empreendimento vive esta fase. Desta feita, os riscos inerentes a este ciclo têm natureza distinta daqueles identificados no ciclo de implantação, a saber:

- manutenção da inserção de mercado e da competitividade do empreendimento, já que a oferta instalada sempre estará sofrendo os impactos provocados pela atualização de oferta concorrente;

- ambiente econômico, já que este afeta o desempenho das atividades econômicas desenvolvidas nos EELs e, conseqüentemente, o mercado de EELs;

- padrão de demanda não compatível com o produto ofertado, provocando queda nos preços de locação, ou incremento das taxas de vacância;

- aumento dos custos operacionais.

Observando-se os riscos enumerados para o ciclo de operação, nota-se que, na grande maioria, eles são monitoráveis e controláveis. Excetuando-se o ambiente econômico, pode-se agir sobre os demais de forma a mitigá-los ou anulá-los. Para tal, é essencial manter uma gestão centralizada e estruturada, e sistemas de planejamento capazes de identificar desvios de comportamento e promover as devidas correções, seja através de investimentos em readequações funcionais, ou através da racionalização da gestão dos custos operacionais. NRE (2002), sugere como mecanismos de compensação de desvios de comportamento:

- reduzir preços contratuais, estender prazos de carência, ou ainda enfatizar, na medida do possível, diferenciais de qualidade dos serviços e/ou dos sistemas de que se dispõe no edifício; 
- utilizar o Fundo de Reposição de Ativos (FRA) ${ }^{32}$;

- conceber o ELL com base tecnológica de ponta para diminuir a velocidade de obsolescência e/ou com grau de flexibilidade que permita a substituição das tecnologias que suportam a operação dos sistemas, por um longo prazo.

Obedecendo a lógica do mercado, quanto maior o risco, maior é a remuneração esperada. Desta forma, espera-se uma rentabilidade maior do investimento feito no ciclo de implantação do que no de operação, já que a tomada de decisão de investir neste ciclo é mais arrojada, em virtude do maior grau de incerteza das variáveis envolvidas para o sucesso do empreendimento.

Uma hipótese de se investir em EELs com maior grau de proteção é a dissociação das figuras do empreendedor e do investidor, sendo o primeiro o especialista que, por tal condição, aceita riscos de impactos maiores em troca de uma remuneração mais agressiva. Em contrapartida, ao investidor cabe a figura de administrador de recursos que aceita riscos controlados em troca de uma remuneração mais modesta. Neste sentido, como será tratado adiante, a securitização de EELs dá abertura para a operacionalização desta hipótese na medida que possibilita a criação de títulos de investimento protegidos por outros de caráter mais agressivo.

\section{7 Origem dos recursos para a implantação de EELs}

A concentração dos recursos necessários à implantação de EELs faz com que o capital dos empreendedores por si só não seja suficiente para suportar a demanda de mercado. Além

\footnotetext{
${ }^{32}$ O FRA é um fundo constituído para a adequação e atualização funcional, que será tanto maior quanto mais intensa for a velocidade de evolução (tecnológica, arquitetônica etc.) dos EELs, funcionando como ação compensatória para perdas de competitividade decorrentes das atualizações praticadas pelo mercado.
} 
disso, o longo payback característico de empreendimentos destinados à renda, impede a atuação dos empreendedores em regime operacional pleno, causando hiatos entre as ações empreendedoras.

Em economias mais estruturadas que tenham um maior poder de financiamento, como por exemplo, a economia americana, a implantação dos EELs é feita com um pequeno aporte de capitais do empreendedor somado a financiamentos de longo prazo de liquidação e com carência para a amortização. Esta configuração apresenta um grau de alavancagem maior, fazendo com que o payback do capital de investimento seja bem mais curto, proporcionando maior agilidade aos empreendedores.

No Brasil, o FINEM ${ }^{33}$ do BNDES (Banco Nacional de Desenvolvimento Econômico e Social) é uma linha de financiamento para implantação de empreendimentos de base imobiliária, bastante utilizada no passado para alavancar empreendimentos hoteleiros. Atualmente, as restrições ${ }^{34}$ impostas pelo BNDES inibem a sua utilização.

Sendo assim, em virtude da carência de estruturas de financiamento voltadas ao mercado da Construção Civil, a alternativa encontrada pelo setor foi buscar os recursos de poupanças conservadoras $^{35}$ que encontram nos EELs uma opção de investimento para a obtenção de uma renda mensal perene e homogênea. Segundo Rocha Lima ${ }^{36}$, o histórico de comportamento do

33 O FINEM é um programa destinado ao financiamento de empreendimentos em geral, para a realização de projetos de implantação, expansão e modernização, incluída a aquisição de máquinas e equipamentos novos, de fabricação nacional, credenciados pelo BNDES, e capital de giro associado, realizado diretamente com o BNDES ou através das instituições financeiras credenciadas.

${ }^{34}$ Empreendimentos imobiliários, tais como edificações residenciais, time-sharing, hotel-residência e loteamento não são passíveis de apoio do BNDES.

${ }^{35}$ Refere-se aqui à parte não consumida da renda para a qual busca-se uma aplicação conservadora, e não apenas aos instrumentos financeiros de poupança.

${ }^{36}$ Rocha Lima (Escola Politécnica, São Paulo). Concurso de professor titular, 2005. 
mercado de real estate brasileiro permite afirmar que recursos de poupanças conservadoras das famílias têm sido regularmente aplicados em EBI, diretamente, ou via Fundos de Pensão.

Neste cenário de carência de estruturas específicas para o financiamento de seus produtos, a solução encontrada pelos empreendedores para captar recursos da poupança conservadora é a partição do empreendimento em unidades acessíveis aos potenciais poupadores ${ }^{37}$, contribuindo para o mercado apenas no ciclo de implantação, após o qual o investidor (poupador) passa a explorar o imóvel para renda. Sendo assim, os EELs passam de meios de investimento a instrumentos de poupança, nos quais impera a falta de comprometimento, no ciclo de operação, do empreendedor responsável pela implantação, premiando suas ações especulativas.

Por outro lado, o comportamento mais recente do mercado de real estate denota uma aversão ao risco das formas tradicionais de investimento, focadas no partilhamento dos imóveis em pequenas unidades. Esta aversão pode ser justificada por experiências negativas vivenciadas por investidores ${ }^{38}$, já que estes são, usualmente, poupadores não alinhados com o desenvolvimento do mercado e com os riscos envolvidos. Sendo assim, a tendência é que o mercado, baseado em experiências amadoras, decida mal.

Neste sentido, modelos mais modernos de investimento em real estate que ganharam destaque em mercados mais avançados a partir da década de 90 (como no mercado americano), já estão sendo experimentados no Brasil. Esses modelos se resumem a procedimentos de securitização, de sorte que o empreendimento é gerido sob um único critério e o investimento

\footnotetext{
${ }^{37}$ Como será explorado mais adiante, esses poupadores podem ser tanto pessoas físicas como investidores institucionais.

${ }^{38}$ Como, por exemplo, o caso dos flats em São Paulo, mercado no qual desenvolveram-se operações de caráter claramente especulativo, cujas expectativas de comportamento não se confirmaram no mercado recessivo
} 
é perpetrado por meio de títulos de investimento, que, ancorados no EEL, podem apresentar qualquer nível de partilhamento, sem comprometer a unidade do empreendimento, possibilitando uma gestão especializada e comprometida com o desempenho.

Segundo Rocha Lima ${ }^{36}$, os sucessos destas experiências no mercado brasileiro se repetem timidamente e as ações não se multiplicam com a velocidade que a capacidade de poupança disponível pode absorver, por duas razões: [i] a acomodação dos empreendedores e a inércia da oferta [ii] o mercado secundário ainda não apresenta escala suficiente para emular os empreendedores e infundir confiança nos investidores.

\section{8 Recuperacão do mercado de edifícios: o novo ciclo da demanda}

Para que os títulos (ou quotas) da securitização de EELs sejam atraentes aos investidores, é necessário que os empreendimentos que os ancoram sejam capazes de gerar renda nos padrões de atratividade percebidos pelo mercado. Ou seja, quanto melhores forem as condições de geração de renda dos EELs, mais rentáveis serão as aplicações feitas nos papéis de sua securitização e, por conseguinte, maior será o interesse dos investidores na aplicação de recursos neste mercado. Em cenários como este, cresce a possibilidade de aquecimento do mercado secundário, aumentando o poder de atração dos papéis que oferecerão flexibilidade suficiente para que os investidores entrem e saiam do mercado nos momentos que melhor lhes convierem.

Objetivando o re-direcionamento dos recursos da poupança conservadora, em mercados de securitização incipientes, como é o caso do brasileiro, é necessário comprovar a segurança e a rentabilidade do investimento para que a cultura da aplicação de recursos em papéis da

desde 2002, tendo os investidores, na origem, feito a imagem de investimentos de renda fixa, sem riscos de flutuação. 
securitização seja sedimentada, transpondo, assim, os obstáculos do desconhecimento e do receio injustificado. Em se tratando de atrair pequenos e médios investidores, esse processo de afirmação é ainda mais relevante, sendo essencial que a securitização se expanda em ciclos do mercado de EELs favoráveis ao investimento.

Neste sentido, analisa-se a conjuntura atual do mercado de EELs com o intuito de apresentar as características das etapas do ciclo do mesmo que indicam condições propícias ao desenvolvimento de EELs nos padrões de atratividade percebidos pelo mercado. Sendo assim, o objetivo não é profetizar sobre a retomada da atratividade do mercado que atualmente apresenta um quadro recessivo, mas sim pautar a discussão do desenvolvimento da securitização no mercado brasileiro nas diferentes fases do mercado de EEL.

Vale lembrar ainda que um cenário de mercado propício à entrada de nova oferta de espaços, não é condicionante da garantia de qualidade de determinado investimento ancorado em EELs. Para tanto, é necessária uma análise do empreendimento em si, considerando, obviamente, as condições de mercado e as expectativas que se apresentam para o período de operação do empreendimento.

Desta forma, a análise do mercado tem caráter de representar o comportamento médio dos empreendimentos, mantendo a discussão neste patamar, sem a pretensão de julgar um empreendimento específico.

Rocha Lima e Alencar (2004a) apresentam a remuneração dos EELs de alto padrão na cidade de São Paulo, conforme Figura 4. 


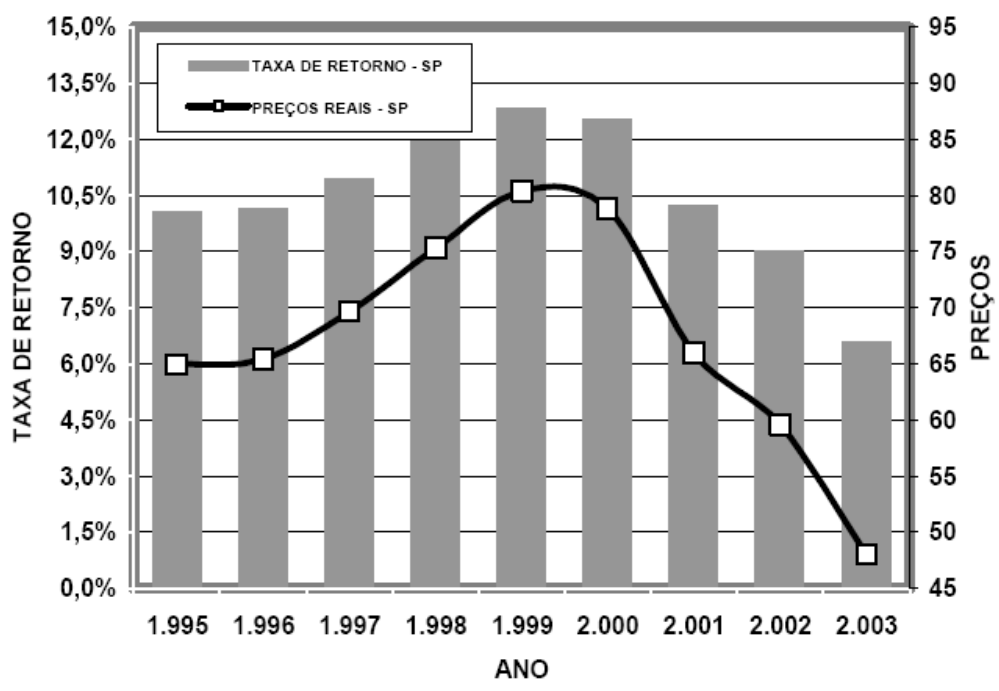

Figura 4 - Remuneração de edifícios comerciais de alto padrão nos mercados de São Paulo (fonte: Rocha Lima e Alencar, 2004)

Depreende-se da Figura 4 que as taxas de retorno mais atrativas referem-se aos anos de 1999 e 2000, período no qual houve elevado volume de oferta de novos espaços, juntamente com um expressivo volume de lançamentos inseridos no mercado ao longo de 2002 e 2003 (ROCHA LIMA; ALENCAR - 2004a). Esta constatação reforça a preocupação com a falta de informação e de análises superficiais presentes no mercado, levando empreendedores e investidores a tomar decisões equivocadas, agravando cenários recessivos.

Em conjunto com o aumento da oferta de EELs entre 2002 e 2003, houve uma intensa deterioração das expectativas do mercado com relação à expansão da atividade econômica e o aumento da percepção do risco Brasil, trazendo a retração dos investimentos nos setores industrial e de serviço, agravando o quadro recessivo que se delineava para o mercado paulistano de EELs.

Neste cenário, a recuperação do mercado paulistano de EELs está vinculada, entre outros, à retomada do crescimento macroeconômico com a respectiva expansão da atividade na área metropolitana de São Paulo, e ao posicionamento dos empreendedores frente à ocupação do estoque ocioso e à expectativa do binômio [risco x retorno] de novos empreendimentos. Com 
base nestes dois fatores, Rocha Lima; Alencar (2004a) fizeram simulações com o objetivo de traçar um cenário para os próximos anos, capaz de apontar a capacidade de reorganização dos preços do mercado paulistano de EELs a partir da análise da conjuntura do mercado de 2003 e de uma projeção da evolução do Produto Interno Bruto (PIB $)^{39}$. Como resultado deste estudo os autores chegaram a projeções sobre os prazos necessários a:

- recuperação dos padrões de remuneração considerados atrativos no mercado de EELs;

- ocupação do estoque ocioso que se tem atualmente nas principais áreas de concentração de EELs na cidade de São Paulo.

O cenário do mercado de EELs em 2003 é utilizado pelos autores como ponto de partida para as simulações de projeção da demanda, reconhecendo-se, entretanto, que seria incorreto assumir que este seja um quadro perene, já que retrata um momento de crise, no qual os valores dos aluguéis apresentam uma relação não interessante com os preços para comprar e investir, inviabilizando a oferta de novos espaços.

No estudo, os autores validam os coeficientes de correlação encontrados na série histórica pós Plano Real (de 1995 a 2000) da evolução do PIB contra a dos preços de aluguéis e contra a da absorção de estoque. No entanto, vale ressaltar que, de acordo com o estágio de evolução da economia, os coeficientes de correlação entre a expansão macroeconômica e a performance do setor de EEL podem flutuar, caso a estrutura econômica esteja baseada em atividades que demandem menos áreas de escritórios, ou em função de mudanças tecnológicas e gerenciais

39 Na literatura especializada publicada na última década, há uma série de trabalhos desenvolvidos, principalmente a partir do comportamento dos mercados americanos, do Reino Unido e de algumas cidades do sudeste asiático, reforçando a intensa correlação existente entre a performance do setor de EELs e a taxa de expansão do PIB nesses países, corroborando o exposto anteriormente sobre os ciclos dos EELs. 
que conduzam a solicitações ou absorções distintas de áreas de escritórios para locação para taxas idênticas de crescimento do PIB.

A partir das séries históricas e de arbitragens para a evolução do PIB, os autores lançam expectativas quanto ao prazo médio para a recuperação do patamar de atratividade percebida para os investimentos no setor de EELs, arbitrado como sendo a taxa de $10 \%$ efetiva, anual média. Para as simulações os autores utilizam dois cenários de evolução do PIB, seguindo as referências:

- meta estabelecida no Plano Plurianual (PPA) do Governo Federal: 4,5\% ao ano em média;

- patamar médio de evolução do PIB no período de 1995 a 2002: 2\% ao ano.

Outras premissas assumidas por Rocha Lima e Alencar (2004a) são:

- preço médio de locação de EEL: $\mathrm{R} \$ 65$ por $\mathrm{m}^{2}$, encontrado a partir do valor médio das transações de compra de EELs prontos para operar de $\mathrm{R} \$ 5.700$ por $\mathrm{m}^{2}$ de $\mathrm{ABR}$, considerando-se ainda os custos de gestão do investimento (12\% da receita operacional bruta) e o alcance do patamar de atratividade setorial (10\% efetiva, anual média);

- não ocorrência de novo excesso de oferta no mercado embasada em percepções equivocadas dos empreendedores com relação ao potencial do mercado quando do seu reaquecimento. Este é um fenômeno comum quando alguns agentes de mercado se aproveitam da falta de informações disponíveis sobre o setor para criar altas expectativas com relação às taxas de retorno potenciais que se imagina auferir.

\subsubsection{Absorcão do estoque ocioso de EEL de alto padrão na cidade de São Paulo}

Nos quadrantes dos ciclos de comportamento de EELs, apresentados no início deste trabalho, a transição do quadrante de Recessão para o de Recuperação se dá com o aumento das taxas 
de ocupação e com os preços ainda abaixo do patamar de atratividade setorial. Além disso, o quadrante de Recuperação caracteriza-se pela evolução em direção ao patamar de atratividade setorial, que ainda não é cenário suficientemente favorável para a sedimentação da cultura de investimento em papéis securitizados.

Confrontando a evolução do PIB (indicador do desenvolvimento econômico) com a potencial absorção de estoque disponível, Rocha Lima e Alencar (2004a) chegaram aos dados expostos na Figura 5 que indicam que entre 2007 e 2008, o estoque atual de espaços desocupados poderá ser anulado em função do crescimento econômico aqui representado pelo PIB. A partir de então, a demanda por novos espaços deve se expandir.

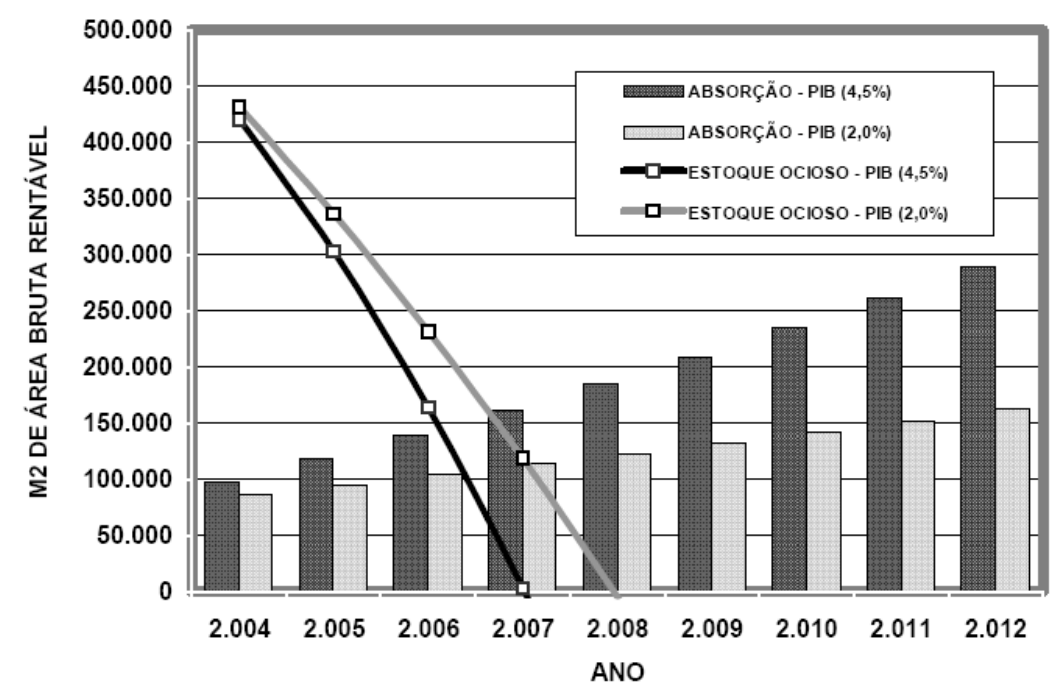

Figura 5 - Absorção de edifícios comerciais de alto padrão nos mercados de São Paulo - Evolução do PIB (\%) 4,5 e 2,0 (fonte: Rocha Lima e Alencar, 2004)

Desta forma, o quadrante de Recuperação ocorreria até 2007, ou 2008, variando conforme o nível de aquecimento econômico provoque a re-ocupação do estoque ocioso e o incremento dos preços de locação. 


\subsubsection{Recuperacão dos patamares de atratividade de investimento no setor de EELs na cidade de São Paulo}

A partir da recuperação, o mercado entraria no quadrante de Expansão, apresentando uma taxa de ocupação nos patamares históricos e incrementos no preço médio de locação. A duração deste ciclo de Expansão varia conforme o desenvolvimento da curva de oferta se dê frente à de demanda. Em outras palavras, conforme os empreendimentos sejam formatados e ofertados em concordância com o perfil e com o volume da demanda, o quadrante de Expansão se mantém, até que haja uma nova oferta injustificável frente à demanda, levando o mercado ao ciclo de Maturação e em seguida a uma nova recessão.

O quadrante de Expansão é o que apresenta as condições mais favoráveis ao desenvolvimento do mercado de securitização de EELs, já que propicia o desempenho de seus papéis (títulos, ou quotas) nos patamares de atratividade esperados pelo mercado, aumentando o poder de atração de novos investidores na medida em que correspondem às expectativas geradas quando da aplicação de recursos neste vetor de investimento.

Com base nos dados e premissas apresentados acima, Rocha Lima e Alencar (2004a) chegaram aos gráficos da Figura 6 e da Figura 7, concluindo que, com uma taxa média de expansão do PIB de 4,5\%, em 2007 será possível atingir patamares de preço que conduzam o investidor à remuneração média de $10 \%$ equivalente anual, admitida como a taxa de atratividade setorial e, portanto, representante da retomada de atratividade de investimentos para o mercado. Já para a simulação de evolução do PIB de $2 \%$ ao ano, o mercado retomaria a atratividade apenas em 2012, podendo acarretar, segundo os autores do estudo em estagnação de oferta nova, ou rebalizamento para baixo da taxa de atratividade setorial. 


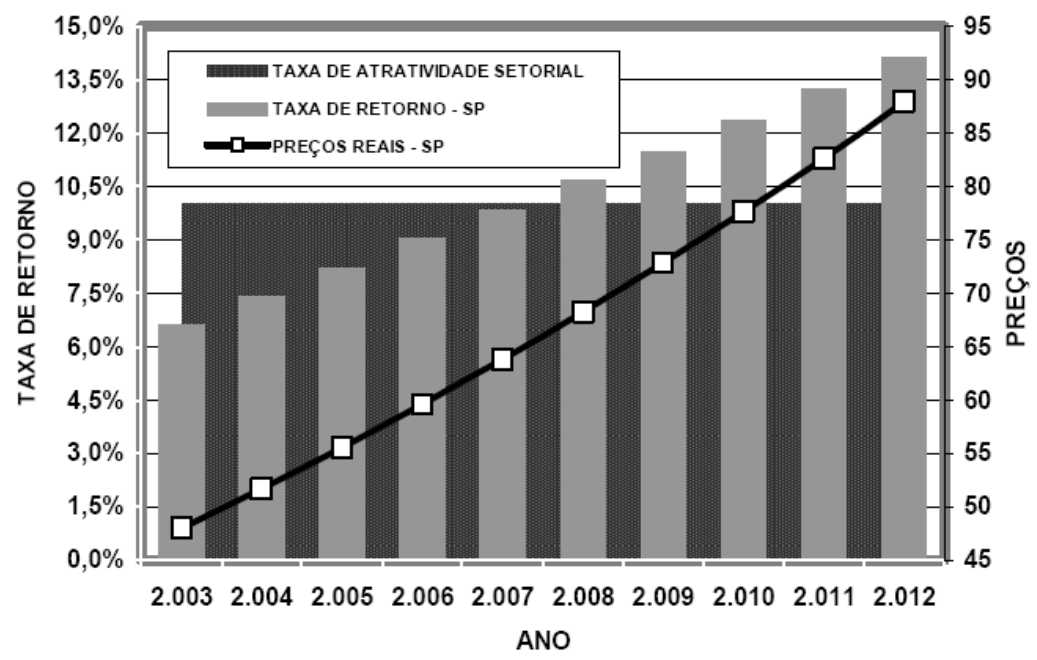

Figura 6 - Remuneração de edifícios comerciais de alto padrão nos mercados de São Paulo, considerando a evolução média anual do PIB de 4,5\% (fonte: Rocha Lima e Alencar, 2004a)

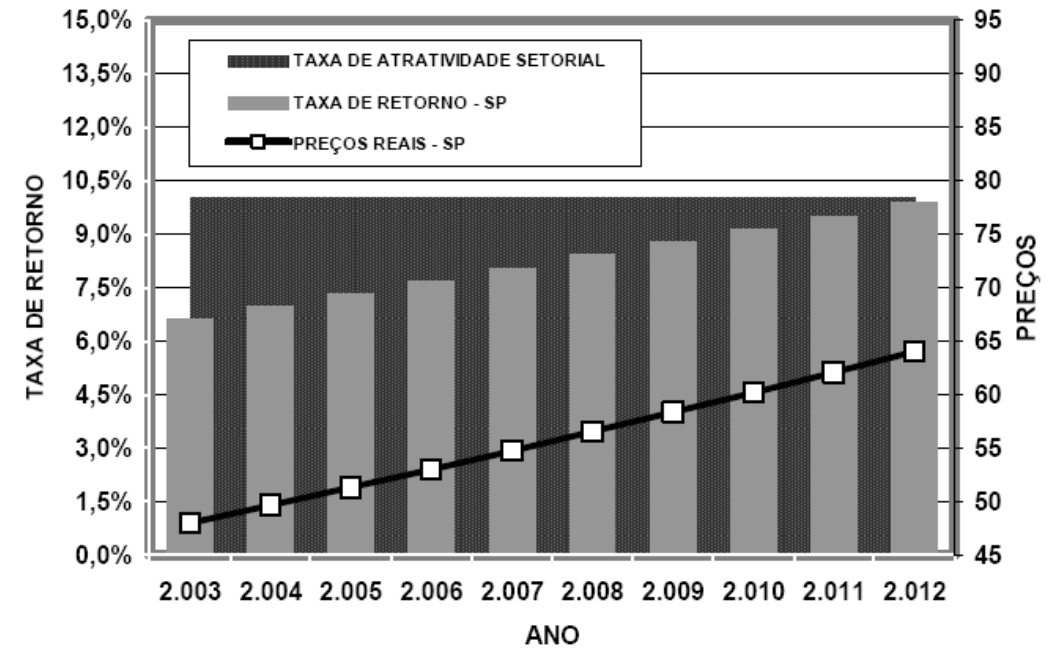

Figura 7 - Remuneração de edifícios comerciais de alto padrão nos mercados de São Paulo considerando a evolução média anual do PIB de 2,0\% (fonte: Rocha Lima e Alencar, 2004a)

Considerando a premissa adotada de que não haja nova oferta expressiva de espaços durante o período de recuperação do patamar de atratividade setorial, é mister salientar que, caso a premissa não seja validada, os prazos de recuperação a que os autores chegaram poderão ser expandidos. Levando em conta [i] a falta de informações disponíveis e suficientemente isentas de interesses a respeito do mercado e que, [ii] no período de recuperação, haverá sinalização 
de reaquecimento oriundo do incremento dos aluguéis (que reflete em uma taxa de retorno próxima a taxa de atratividade setorial) e da re-ocupação dos estoques atualmente disponíveis; uma nova oferta expressiva de estoque pode acontecer, antes que o mercado apresente rentabilidade acima do patamar de atratividade.

Supondo que o setor não opere por períodos significativos em patamares acima da média setorial, teríamos uma nova crise de super oferta, similar a identificada em 2000 a partir de 2010, ou 2012 (período após o qual os autores projetam rentabilidade acima da atratividade setorial). Se voltarmos às conclusões de Wheaton (1987), notamos que o ciclo recorrente, de 10 a 12 anos, identificado por ele para os Estados Unidos seria validado para o caso paulistano.

Logicamente, não se pode afirmar que os mercados de EELs terão ciclos uniformes, pois como já exposto acima, a maturidade do mercado e o refinamento das informações que levam à tomada de decisão de empreender condicionam a duração dos quadrantes e, portanto do ciclo. Também não se pode afirmar que os ciclos se repetem nos diversos mercados, mas é inevitável a constatação de que a globalização da economia e as trocas comerciais cada vez mais intensas entre as diversas regiões do globo influem no comportamento do mercado de EELs. 


\section{SECURITIZAÇÃO COM LASTRO EM ATIVOS}

"Os meios de securitização, hoje conhecidos como instrumentos eficazes para distribuir investimentos de grande montante por uma plêiade de investidores, mesmo de reduzido poder de investir, sem, com isso, comprometer os princípios de governança necessários para assegurar bom desempenho dos empreendimentos, além de garantir a permanência das regras para repartição dos resultados, que não estão sujeitas à decisão dos investidores, em fortuitas maiorias, no curso do longo horizonte operacional, contribuem para acelerar a migração de capitais de raiz de investimento conservadora para os negócios de base imobiliária. Com isso cresce a oferta de capitais de investimento para a construção de hotéis, shopping-centers, condomínios industriais para locação e até de hospitais” (ROCHA LIMA p.3, 2001a).

\section{1 O conceito da securitizacão}

"O termo securitização utilizado no Brasil é um neologismo derivado de securitization, que significa associar a um ativo um título (security), que circula no mercado, ficando o ativo rigidamente ancorado num ambiente próprio (no Brasil, uma Sociedade de Propósito Exclusivo ou um Fundo de Investimento Imobiliário)” (ROCHA LIMA p.4, 2001a).

A securitização pode ser definida como conversão de ativos de pouca liquidez em títulos mobiliários de grande liquidez, passíveis de serem absorvidos pelo mercado investidor (KOTHARI, 1999 apud VEDROSSI, 2002) ${ }^{40}$. Estes títulos mobiliários têm lastro nos ativos objetos de securitização e receitas baseadas em juros sobre empréstimos, ou outros recebíveis originados nos ativos objeto da securitização.

\footnotetext{
${ }^{40}$ KOTHARI, V. Securitisation: the financial instrument of the new millenium. Calcutta: Academy of Financial Services, 1999. 498p.
} 
Rocha Lima (p.4, 1994) define securitização de determinado ativo como o procedimento que "associa a este ativo um título de circulação independente no mercado financeiro ou de capitais, que terá, por via direta, ou indireta, o ativo como lastro. A securitização de portfólios imobiliários compreende a formatação de títulos de investimento presos a estes imóveis, que têm sua renda derivada das ações que se perpetra com os mesmos (venda, arrendamento ou exploração), constituindo-se ainda, no lastro dos títulos".

De forma mais detalhada, a securitização é o procedimento de segregar do ambiente de uma companhia, para um veículo de propósito exclusivo, determinados ativos, contra os quais se emite títulos de investimento, de diferentes formatos, vetor pelo qual se captam recursos para a companhia, ou para desenvolvimento de um projeto particular.

Resumindo, o objetivo da securitização é aglutinar investidores através da colocação de títulos acessíveis aos pequenos investidores no mercado, utilizando como método a segregação do portfólio em um ambiente especial para a emissão de títulos (vetores de investimento) ancorado no portfólio, usando o ambiente como veículo de emissão. Os ambientes e os vetores de investimento possíveis no mercado brasileiro serão tratados adiante.

Qualquer ativo ou portfólio de ativos pode ser objeto de securitização. Os ativos objeto de securitização podem ser de diferentes razões:

- recebíveis gerados na atividade principal do originador (resultado de venda de ativos);

- empreendimentos de base imobiliária em operação, que o empreendedor segrega no veículo de propósito exclusivo; ou

- empreendimentos (imobiliários, ou de base imobiliária) por implantar, dos quais o empreendedor segrega a base já existente do projeto e nesse ambiente ele é implantado, para depois operar, ou ser comercializado. 
Neste trabalho, será abordada apenas a securitização de EEL.

\section{2 Recursos para investimento disponíveis no mercado}

Uma carteira de investimentos, seja de pessoas físicas, seja de instituições, usualmente abriga ativos com diferentes características de risco e remuneração, com o intuito de garantir certa proteção diante dos riscos assumidos e maximizar a remuneração da carteira. No entanto, como a percepção de risco varia consideravelmente entre os investidores, não há uma relação de equilíbrio única, fazendo com que a composição da carteira seja específica de cada gestor em função da aplicabilidade prevista para seus recursos no que tange à liquidez e à conservação, ou incremento de poder de compra.

Desta forma, os investimentos presentes no mercado podem ser classificados segundo o perfil que apresentam: [i] agressivo, [ii] moderado e [iii] conservador. Esta classificação é função do grau de risco e da remuneração esperada em cada investimento, quanto maior for o risco identificado pelos investidores, maior será a remuneração esperada, e mais agressivo é o investimento.

Segundo Rocha Lima ${ }^{36}$, os investimentos conservadores geralmente têm a função de atender a anseios e necessidades futuros e portanto apresentam como requisitos: [i] segurança elevada, caracterizada pelo baixo risco de expressiva flutuação de valor em médio prazo, e [ii] estabilidade na renda, caracterizada pelo baixo risco de flutuação na renda esperada. Dentre os investidores que apresentam este perfil de investimento na maior parte de sua carteira destacam-se: seguradoras (aplicação de recursos vinculada à proteção ao risco), famílias que aplicam diretamente na poupança, ou indiretamente através dos fundos de pensão.

Ainda segundo Rocha $\mathrm{Lima}^{36}$, todo este grau de segurança exigido para investimentos conservadores, confere a eles características peculiares como o lastro evidenciado e de valor 
estável e o fluxo homogêneo de renda, tanto no que se refere ao regime quanto à estabilidade dos valores. É nestas características que o EEL se enquadra como alternativa de investimento, podendo se apresentar de diversas formas, tais como: edifícios built to suit para arrendamento de longo prazo e edifícios de escritórios para locação.

É importante ressaltar que a estabilidade de valor do lastro dado pelos EELs está vinculada à manutenção dos padrões de geração de renda, sendo que a homogeneidade da renda é função da competitividade no mercado que se conserva com investimentos contínuos em adequação e atualização funcional $^{41}$. Estas implicações fazem com que os EELs exijam uma gestão centralizada que coordene esforços em prol do todo, o que recai usualmente na visão do EEL como uma unidade de investimento, acessível apenas para grandes investidores.

De outro lado, os pequenos e médios investidores aglutinam um importante potencial de poupança, vide as aplicações diretas de pessoas físicas e indiretas via fundos de pensão. Este público enxerga na aquisição de unidades de escritórios, a oportunidade de investir no mercado de EEL, partilhando fisicamente ${ }^{42}$ a unidade de investimento, o que leva à uma gestão descentralizada, implicando em perda de competitividade e de valor, refletidas no aumento da dispersão do fluxo de renda ${ }^{43}$.

Rocha Lima $^{36}$ faz uma leitura do ponto de vista do mercado, afirmando que as grandes unidades de investimento não são referência válida para registrar flutuação de valor do lastro

\footnotetext{
${ }^{41}$ Como já mencionado anteriormente na discussão sobre as características do mercado de EEL, os EBIs, de uma forma geral, estão inseridos em um mercado dinâmico, onde as necessidades dos usuários se reconfiguram frente às inovações tecnológicas, gerenciais etc., sendo vital a adequação e a atualização para que o empreendimento permaneça competitivo.

${ }^{42}$ Utilizo a expressão partilhamento físico da unidade de investimento em referência à aquisição de unidades de um EEL, o que acarreta a descentralização da gestão e em perda de competitividade. Procuro assim, distinguir este partilhamento daquele inerente aos papéis de securitização.

43 Esta afirmação é embasada em casos reais onde a descentralização da gestão usualmente descaracteriza o empreendimento, prejudicando sua inserção de mercado e, conseqüentemente, sua competitividade.
} 
dos EELs, dificultando a avaliação do mesmo e corroborando a utilização de unidades de investimento menores com o objetivo de fomentar a ocorrência de transações e, conseqüentemente a aferição de valor dos investimentos.

Ou seja, há investidores que têm interesse no mercado e que tradicionalmente investem em unidades de EELs, assumindo o aumento do risco da manutenção da inserção de mercado, em virtude da descentralização da gestão do empreendimento. Por outro lado, há a necessidade de captar recursos para o desenvolvimento do mercado de EELs, já que o capital dos próprios empreendedores não é capaz de suprir as necessidades do mercado. Por fim, o aumento das transações ancoradas em EELs possibilita o registro da flutuação de valor, trazendo mais transparência a este mercado.

Neste cenário, o fracionamento do investimento em EELs confere qualidade ao investimento, a partir do momento que não exige dos investidores a aplicação de grandes volumes de recursos, possibilitando o investimento em empreendimentos diversos, contribuindo, assim, para a diluição do risco. Além disso, a criação de meios de acesso para os pequenos e médios investidores aumenta o poder de investimento no mercado, uma vez que o volume de recursos da poupança (direta e indireta) é expressivo. No entanto, estes meios de acesso não devem permitir o fracionamento da gestão provocada pelas transações de unidades físicas de um mesmo EEL, já que a gestão descentralizada do EEL implica na perda de competitividade, comprometendo o valor e a estabilidade da renda.

Com isso em mente, uma solução que supere os riscos de perda de qualidade no partilhamento físico dos EELs, mantendo a gestão centralizada, criará um poderoso produto de investimento para grandes, pequenos e médios investidores. É essa a idéia da securitização de EELs que terá suas características apresentadas nos itens a seguir. 


\section{3 Principais elementos envolvidos no processo de securitizacão}

Durante o estudo da securitização, especialmente aquela voltada ao mercado de edifícios de escritórios, é importante ter em mente que a interação dos agentes pode afetar o desempenho do processo. A despeito do mesmo envolver inúmeros agentes e detalhes específicos, pode-se ressaltar os cinco elementos abaixo como aqueles nos quais o processo mantém foco:

- empresa - originadora do empreendimento;

- empreendimento - para o qual se busca uma alternativa de captação de recursos;

- mercado imobiliário no qual o empreendimento se insere - como cenário que influencia no retorno esperado no empreendimento;

- mercado de investimentos - como fonte de outras alternativas de investimento;

- investidor - como comprador de papéis atrativos disponíveis no mercado de investimento, visando a composição de um portfólio equilibrado ${ }^{44}$.

Conforme a conjuntura econômica que afeta o binômio [risco x remuneração], estes subsistemas interagem entre si de modo a favorecer, ou não, a securitização.

\section{4 Vantagens proporcionadas pela securitizacão}

As principais vantagens oferecidas por este procedimento aos agentes nele envolvidos são:

\footnotetext{
${ }^{44}$ Cada investidor tem sua própria percepção de risco e, portanto, o equilíbrio citado é relativo e não facilmente identificado.
} 


\subsubsection{Para o empreendedor/ originador:}

1) Mitigação do risco de não captar os recursos necessários à implantação do empreendimento, uma vez que a captação é feita de forma pulverizada, libertando o empreendedor da dependência de um grupo pequeno e restrito de grandes investidores.

Tradicionalmente, a equação de fundos de um EEL é construída com três fontes de recursos: capital próprio dos empreendedores, recursos da comercialização de unidades (partilhamento físico do investimento) e recursos de financiamento obtidos junto às instituições financeiras. Usualmente, na comercialização de unidades, os compradores comprometem-se a aportar algo em torno de $40 \%$ do preço acordado para a unidade durante a construção, portanto, apesar dos recursos da comercialização contribuírem para a equação de fundos, eles não são capazes de sustentar a implantação do empreendimento. Sendo assim, os empreendedores recorrem aos bancos, que, por não atuarem diretamente no setor, procuram se proteger do risco de inadimplência, criando restrições para a aprovação do financiamento.

A securitização possibilita que o empreendedor encontre investidores que aceitem os riscos inerentes ao mercado de EEL através da pulverização da captação de recursos, minimizando, ou até mesmo anulando a necessidade de financiamentos bancários.

2) Compartilhamento dos riscos de insucesso do empreendimento com os investidores, na medida que os mesmos possuem quotas (ou qualquer outro tipo de participação) do empreendimento, ou seja, a rentabilidade do investidor está atrelada ao sucesso do empreendimento.

Quando tomam financiamentos bancários, os empreendedores desvinculam a geração de renda do EEL do compromisso de quitar o financiamento. Ou seja, assumem o 
compromisso de remunerar o capital da instituição financeira, independentemente da remuneração de seu próprio capital. Na securitização, o risco do empreendimento não é desvinculado da aplicação de recursos, ou seja, por mais que o empreendedor dê garantias e privilégios aos papéis da securitização, o lastro continua sendo o EEL e a renda gerada por ele. Desta forma, o empreendedor compartilha, em maior, ou menor grau, os riscos do EEL com os investidores.

3) Possibilidade de redução do custo do funding.

As altas taxas de juros praticados no Brasil fazem com que o financiamento bancário traga um grande ônus financeiro para o empreendedor. Na securitização o empreendedor tem custos na estruturação e na colocação dos papéis, mas conforme o volume de recursos que pretende captar, a pulverização e a proteção ao risco que pretende oferecer aos investidores, estes custos são inferiores ao ônus financeiro do financiamento tradicional.

Rocha Lima (2006) cita que, utilizando um exemplo paramétrico, considerando uma implantação de 30 meses, os recursos recebidos antecipadamente pelo empreendedor custam no patamar de $23 \%$ ano, nominal, valor muito inferior ao da taxa de atratividade dos negócios no setor. Ou seja, a securitização é uma forma de captar recursos que possibilita uma alavancagem efetiva do investimento do empreendedor.

\subsubsection{Para o investidor:}

1) Maior transparência na negociação de empreendimentos de real estate, pois a análise de valor do empreendimento é feita em períodos curtos, uma vez que os títulos conferem uma liquidez muito superior à do mercado imobiliário convencional. Sendo assim, tem-se em curtos períodos a sensibilidade do mercado com relação ao valor do empreendimento. 
A liquidez dos papéis da securitização e o conseqüente aumento das transações fazem com que o mercado analise o valor destes papéis em períodos muito mais curtos do que os ciclos do mercado de EEL. Desta forma, pode-se criar índices que retratem as condições de mercado e disponibilizem ao investidor informações mais apuradas e livres de interesses dos agentes que nele operam. Para tanto, é essencial o aquecimento do mercado secundário.

2) Devido à maior liquidez e transparência, o investidor tem a opção de decidir qual período do ciclo de vida do empreendimento lhe é mais atraente.

Quando o mercado secundário é desenvolvido, o investidor pode negociar seus ativos lastreados em EELs de maneira rápida e sem a burocracia da transferência da propriedade de imóveis que permeia o mercado tradicional. Desta forma, o prazo de aplicação de seus recursos nos papéis da securitização de EELs é vinculada apenas ao seu desejo de manter tal posição. Ou seja, a facilidade da negociação dos papéis traz ao investidor a possibilidade de optar por qual período e em qual fase do empreendimento que ancora os papéis ele quer investir.

3) Unidade de valor menor para o investimento.

Quando um investidor aplica seus recursos de forma tradicional no mercado de EEL, ou seja, comprando e locando unidades de escritórios, ele só pode se desfazer de sua posição de investidor transacionando a propriedade como um todo. Ou seja, o investimento necessário para que ele tenha os rendimentos e os riscos do mercado de EELs corresponde à unidade locável.

A securitização possibilita a criação de papéis com pequeno valor de face, ou seja, para adquiri-los o investidor deverá dispor de um volume de recursos bem inferior àqueles imobilizados na aquisição de uma unidade física de investimento. Desta forma, facilita-se a 
entrada de pequenos investidores no mercado de EELs, assim como a transação dos papéis no mercado secundário.

4) Construção de um portfólio diversificado e aumento da flexibilidade no gerenciamento da carteira.

A maior liquidez e a menor unidade de investimento proporcionam ao investidor maior flexibilidade na composição de sua carteira. No investimento tradicional a parte da carteira ancorada em EELs é lastreada em um, ou em poucos empreendimentos. Já a carteira composta por papéis de EELs securitizados possibilita que o investidor aplique recursos em vários empreendimento, mitigando os riscos a que se expõe (os riscos setoriais continuam presentes, apenas é possível reduzir o impacto do mau desempenho que um empreendimento específico traga para a carteira).

O amadurecimento da securitização estende esta flexibilidade a todo o mercado, fazendo com que os próprios ambientes (FIIs e SPEs) construam portfólios equilibrados, deixando de abrigar apenas um imóvel. No mercado americano isto já é uma realidade, lá os REITs possuem em carteira diversos imóveis e papéis de outros REITs, proporcionando, além de investimentos mais seguros, o aquecimento do mercado secundário.

5) Redução dos custos de transferência do investimento.

A comercialização tradicional de EELs obriga os compradores a incorrer em despesas de registro e transferência de imóveis, fazendo com que o mesmo disponha de recursos para a aquisição e regularização dos imóveis. Estas despesas ocorrem a cada transferência de propriedade. Já na securitização, estas despesas inexistem, uma vez que se negociam papéis lastreados em EELs, e não o empreendimento propriamente dito. 


\subsubsection{Para o desenvolvimento do mercado de EELs:}

1) Aumento do universo de captação de recursos, gerando um aquecimento do setor do EELs.

A possibilidade de pulverizar a captação de recursos traz para o setor de EELs recursos antes aplicados em outras formas de investimento, aumentando o volume de recursos potencialmente dirigíveis a este mercado. Sendo assim, mitiga-se o risco da não disponibilidade de recursos para o desenvolvimento de determinado empreendimento, diminuindo o impacto desta que é uma restrição severa ao desenvolvimento do mercado.

2) O aquecimento do setor possibilita a diversificação de investimentos, e conseqüentemente, a redução dos riscos através da busca de um portfólio equilibrado.

Com o aumento dos recursos disponíveis para a composição da equação de fundos de EELs, o mercado se aquece, ofertando um volume maior de empreendimentos em momentos de demanda. Com o mercado mais aquecido e dinâmico, onde as transações ocorrem em períodos curtos, aumenta-se as opções de investimento, possibilitando aos investidores a construção de carteiras lastreadas em diversos empreendimentos, localizados em diferentes regiões e em diferentes estágios do ciclo de vida. Essa diversificação faz com que o comportamento das carteiras se aproxime da média de mercado, apresentando o risco intrínseco do setor, e não o risco de um empreendimento específico.

3) O aumento das opções de investimento atrai mais investidores para o mercado.

Quanto mais dinâmico e variado for o mercado de papéis da securitização de EELs, maior será o número de investidores que encontrará em seus títulos (ou quotas) características que se alinhem com os objetivos de investimento. O mercado passará então a ter como fonte de recursos agentes ativos que buscam a rentabilidade oferecida pelo setor, e não mais agentes 
passivos que aportam recursos com o intuito de obter rentabilidade sobre dívida, como é o caso das instituições financeiras.

\section{5 Posicionamento do investimento em vetores de securitizacão em relacão ao investimento imobiliário tradicional}

Como todo o investimento está atrelado de alguma forma a riscos, os investidores tomam a decisão de investir baseados na análise do binômio [rentabilidade x risco]. Cabe aos investidores a arbitragem de cada uma das fronteiras sob as quais ele considera, ou não a possibilidade de aplicar seus recursos. Quanto mais agressivo for seu perfil, mais risco ele aceita tomar e conseqüentemente, a menos de paradoxos econômicos, maior será sua rentabilidade.

A Figura 8 apresenta uma régua para o binômio [rentabilidade x risco] de um investidor não aparente habituado a investir no setor de EEL.

A fronteira (1) retrata investimentos de risco desprezível, fazendo com que o investidor enxergue os negócios desta fronteira como isentos de risco. Neste patamar, estão os investimentos disponíveis na economia fora do mercado de real estate para os quais o investidor obtém a melhor rentabilidade possível, denominada de custo de oportunidade. Para um investidor não aparente, pode-se considerar aqui a rentabilidade dos títulos públicos de longo prazo como custo de oportunidade.

A fronteira (2) retrata investimentos do setor de EEL que estejam expostos a riscos controlados e aos riscos do próprio mercado, definindo assim uma fronteira com um prêmio pelo risco representando pelo aumento da rentabilidade em relação do custo de oportunidade. 


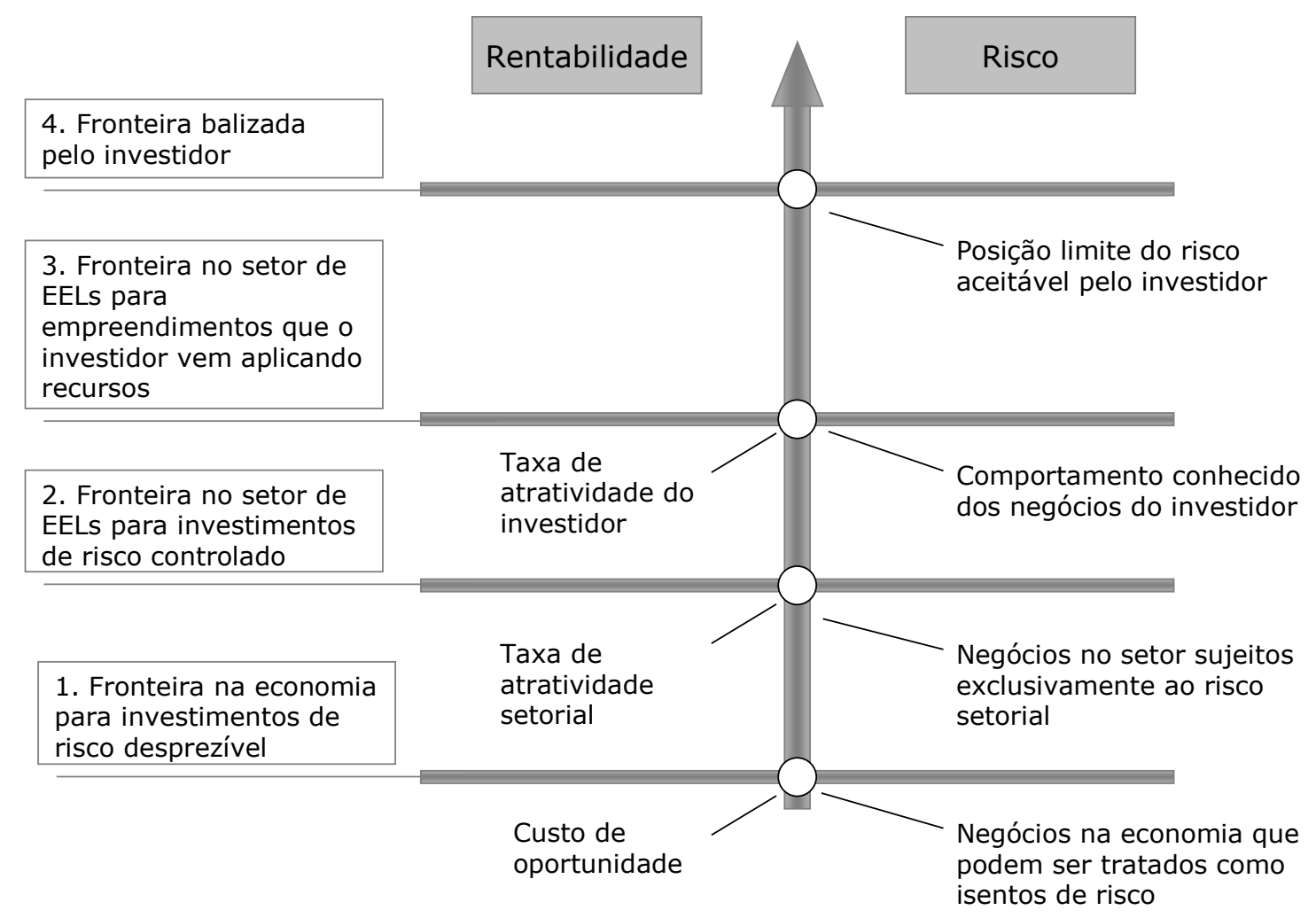

Figura 8 - Hierarquia dos negócios no mercado de EELs (adaptação de Rocha Lima, 2004)

A fronteira (3) representa os investimentos nos quais o investidor está habituado a aplicar seus recursos, tendo o histórico da rentabilidade que vem obtendo e dos riscos aos quais se expõe para atingí-la.

A fronteira (4) apresenta o limite de risco ao qual o investidor aceita se submeter para atingir rentabilidades superiores às que está habituado.

Quanto mais conservador for o investidor, mais próximo das fronteiras setoriais ele montará sua posição.

Para ilustrar o posicionamento do investimento em vetores de securitização, quando comparado com o do investimento imobiliário direto, estuda-se as seguintes hipóteses de um investidor estruturar uma carteira ancorada em EELs com o mesmo valor patrimonial: 
- aplicar recursos em um único EEL (empreendimento de base imobiliária), ou

- aplicar recursos em títulos, ou quotas lastreados em EELs (investimento de base

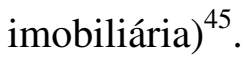

Tem-se que o primeiro apresentará uma posição de risco e rentabilidade acima da fronteira (2), enquanto que o segundo se localizará próximo a esta. Esta posição relativa dos investimentos de base imobiliária se identifica, quanto aos riscos, pela busca de posição segura de investimentos, cuja contrapartida é aceitar rendas conservadoras. A diversificação da carteira propiciada pela securitização promove a redução do impacto dos riscos de empreendimentos específicos, fazendo com que o comportamento da carteira se aproxime da média setorial.

Além disso, comparando a aplicação de recursos em um EEL com o objetivo de auferir renda, com aquela feita em títulos de EELs securitizados, evidencia-se a rigidez relativa do investimento imobiliário tradicional em EEL. Supondo um investidor que, em determinado momento, tenha uma certa capacidade de investimento correspondente ao valor de um imóvel, para montar uma posição de investimento via mercado imobiliário, no formato rígido, o investidor deverá preencher toda a sua carteira de investimentos com o imóvel. Por outro lado, a mesma capacidade de investimento no mercado de capitais (títulos de ativos securitizados) pode ser preenchida em momentos diferentes, buscando melhores oportunidades, em razão da divisibilidade do investimento em títulos. A mesma relação de rigidez se verifica na desmobilização da carteira de investimentos. Em resumo, enquanto no

${ }^{45}$ Faz-se aqui a distinção entre empreendimento de base imobiliária e investimento de base imobiliária. O primeiro diz respeito ao produto em si, pressupondo a necessidade de recursos para o seu desenvolvimento como uma unidade. Já o segundo refere-se ao investimento lastreado em empreendimentos de base imobiliária, sem que haja a necessidade de se dispor dos recursos necessários ao desenvolvimento do empreendimento como um todo. Esta distinção é a essência do processo de securitização. 
mercado de capitais esperam-se prazos curtos para negociação e liquidação da posição de investimento para o encaixe da liquidez pretendida, no mercado imobiliário tradicional, a velocidade de transação é sensivelmente maior.

\section{6 Objetivo da segregacão do ativo}

Como já mencionado anteriormente, os títulos de investimento colocados no mercado devem ser suficientemente atraentes aos investidores para que estes façam parte do processo. Para tanto, é necessário que o binômio [rentabilidade x risco] seja reconhecido pelos investidores. Desta forma, faz-se uso de mecanismos de segregação do ativo objeto da securitização em relação ao originador, possibilitando que o investidor calibre, com elevado grau de segurança, os riscos tomados, uma vez que os riscos de outros ativos do empreendedor não interferem na qualidade do empreendimento, e ações futuras do empreendedor não implicam em quebra da configuração de risco aceita na tomada de decisão de investimento. Sendo assim, o risco está associado unicamente à qualidade do portfólio segregado.

Ou seja, como os investidores de títulos securitizados têm grande interesse na qualidade dos recebíveis e do ativo originado, é essencial que os ativos objeto da securitização sejam segregados da estrutura jurídica do originador, para evitar a contaminação do objeto da securitização por eventuais problemas e/ ou falhas na estrutura do originador, garantindo a manutenção da qualidade dos títulos securitizados.

\section{7 Ambientes utilizados para a securitização no mercado brasileiro}

Para proporcionar a segregação do ativo quando da securitização, a legislação brasileira habilita o uso de dois ambientes: 


\subsubsection{Fundo de Investimento Imobiliário (FII)}

Fundo que funciona como um condomínio de investidores, sendo obrigatoriamente administrado por instituição financeira que figura como proprietária fiduciária dos bens integrantes do patrimônio do FII, os quais não se comunicam com o patrimônio da instituição. A legislação brasileira limita o uso destes fundos como ambiente de securitização. Eles só podem ser utilizados se [i] o objetivo do fundo for comprar, vender, alugar ou arrendar imóveis e [ii] quando se pretende conceber sistemas de investimento com risco aberto, sem garantia de renda, nem privilégios para certos investidores em relação a outros. Nos casos em que o ambiente de securitização é um fundo, o vetor de investimento é a quota do fundo.

O retorno do investimento feito em quotas de FIIs ocorre pela distribuição de resultados operacionais, ou pela venda das quotas no mercado secundário. Em um FII, não há o resgate das quotas, ocorrendo a dissolução do mesmo apenas através da venda do imóvel e a respectiva distribuição de resultados aos quotistas.

Pelo menos $75 \%$ do patrimônio do fundo deve estar aplicado em bens e direitos imobiliários, e o saldo em caixa deve ser aplicado em ativos de renda fixa. Além disso, para os casos de fundos destinados a construir imóveis, as integralizações podem ser parceladas em séries. Os fundos podem, também, efetuar aumento de capital mediante a emissão de novas quotas. Apesar do patrimônio de um mesmo FII poder ser composto por vários imóveis, parte deles, ou até mesmo por direitos imobiliários, atualmente, a maioria dos fundos ainda concentra investimentos em um único imóvel.

O Fundo Imobiliário em si é isento de impostos, inclusive Imposto de Renda, que só incide sobre as receitas financeiras obtidas com as aplicações do saldo de caixa do fundo (compensáveis quando da distribuição), mas para que o FII possa ter este benefício tributário, a Lei 9.779/99 estabeleceu os seguintes requisitos: 
- deve haver distribuição de $95 \%$ dos rendimentos aos quotistas, pelo menos a cada seis meses,

- os ativos do FII não podem ser empreendimentos imobiliários que tenham como incorporador construtor ou sócio, quotista que possua, isoladamente ou em conjunto com pessoa a ele ligada, mais de $25 \%$ das quotas do Fundo.

Os rendimentos distribuídos mensalmente aos quotistas pessoas físicas são isentos de imposto de renda, desde que o FII possua pelo menos 50 quotistas e desde que o quotista não detenha mais de $10 \%$ da totalidade de quotas emitidas pelo fundo. Para os demais investidores, incide imposto de renda sobre os rendimentos à alíquota de $20 \%$. Além disso, caso ocorra ganho de capital nas operações de venda de quotas de Fundos de Investimento Imobiliário, é de responsabilidade do quotista o recolhimento de Imposto de Renda sobre o ganho auferido, conforme Lei $\mathrm{n}^{\circ} .11 .033 / 04$.

\subsubsection{Sociedade de Propósito Exclusivo (SPE), nos moldes dos REITs americanos}

Sociedade anônima de capital aberto, com objetivo social restrito, e outros vínculos de gestão, que faz uso de títulos como vetores de investimento. Neste ambiente é possível garantir rendas mínimas e privilégios para certos investidores.

A SPE é o ambiente onde são gerados os títulos e, portanto, para onde são transferidos os ativos. "Constitui-se de uma entidade legal, criada única e exclusivamente com o objetivo de suportar a operação de securitização" (VEDROSSI p.24, 2002). Essas entidades são chamadas Sociedades de Propósito Específico, ou Exclusivo, ou internacionalmente como Special Purpose Vehicles, Special Purpose Entities, ou Special Purpose Companies. 
A SPE é, portanto, um ente passivo, servindo exclusivamente de ambiente da securitização, não tendo sistema gerencial, nem resultado, uma vez que distribui todo o resultado gerado pelos ativos de sua carteira aos investidores detentores dos títulos por ela emitidos.

O estatuto da SPE vincula à decisão dos investidores, ou à de ações preferenciais com voto qualificado, atos da administração tais como: ampliação do objetivo social, alienação do patrimônio representado pelo empreendimento segregado e alteração da forma de pagamento dos rendimentos aos investidores.

Na securitização feita através de uma SPE, “o empreendedor figura como gestor da operação e como 'sócio' do capital que ingressará no seu empreendimento, garantindo a este capital uma remuneração básica e dividindo com ele, numa determinada proporção, os lucros da operação" (ROCHA LIMA p.5, 1990). Ou seja, o empreendedor retém consigo uma parcela dos títulos, como forma de demonstrar seu comprometimento com o negócio, propiciando maior segurança ao investidor, uma vez que ele também tem interesse na geração de renda igual, ou superior àquela admitida quando da formatação do empreendimento e da estruturação da securitização.

Outra forma de atrair investidores salientando o fator segurança é através da formatação de títulos com garantia de uma renda mínima, desta forma, caso o desempenho do empreendimento seja inferior àquele necessário para que a renda mínima seja atingida, a SPE se compromete a remunerar a diferença ao investidor. Esta remuneração via SPE somente é possível pela criação de um fundo garantidor dentro da SPE, ou seja, dos recursos ingressantes na SPE, uma parte é retida neste fundo, repassando-se ao empreendedor o restante para que este providencie a implantação do empreendimento. 
Desta forma, alia-se o conhecimento do mercado imobiliário, representado pela figura do empreendedor, à disponibilidade de recursos dos investidores que não necessariamente conhecem o setor da construção civil.

\section{8 Aspectos que estimulam a securitizacão e sua sustentabilidade}

Para que a securitização seja uma alternativa viável de captação de recursos, Kothari (1999 apud Vedrossi, 2002) ressalta alguns pontos que devem ser analisados:

- facilidade de comercialização - função da possibilidade legal e regulatória da existência do instrumento de securitização e da existência de um mercado investidor para este instrumento;

- atratividade para o mercado. O principal mercado para esses títulos é o de investidores institucionais, como fundos de pensão e seguradoras, mas para que os títulos sejam atraentes para estes investidores, é fundamental que o investimento possua um determinado nível de classificação de risco (rating) dado por empresas independentes e especializadas, oferecendo maior conforto aos investidores na tomada de decisão;

- adequação do valor de face dos títulos à capacidade do investidor. Quanto menor o valor de face de cada título, maior é a quantidade de títulos a ser emitida para compor um determinado volume de emissão, e maiores são os custos de emissão. Deve-se, portanto buscar um equilíbrio entre o valor de face de cada título e seu público-alvo visando à racionalização dos custos de operação. Pode-se emitir títulos separados em lotes homogêneos, agrupados por faixas de valor de face, com o objetivo de atrair investidores variados;

- ambiente econômico. Para que os títulos sejam atraentes, eles devem permitir aos investidores uma remuneração positiva, real e compatível com seu nível de risco. Em 
ambientes econômicos não estáveis, como o brasileiro, os investidores tendem a preferir investimentos de curto prazo, devido à dificuldade de se prever a inflação ou as taxas de juros, o que afeta diretamente o desenvolvimento de operações de securitização, já que sem a demanda por investimento de longo prazo, essas operações não existem;

- ambiente regulatório. A existência de um processo eficiente de execução de garantias é fator de sucesso na criação de um ambiente propício à securitização.

\section{9 Etapas do processo de implantação com securitização}

Tomando-se como base o ciclo de implantação/ comercialização de um EEL, temos as etapas apresentadas na Tabela 1:

\begin{tabular}{l|ll}
\hline \multicolumn{1}{c|}{ Fase } & \multicolumn{1}{c}{ Recursos necessários para } \\
\hline Compra do terreno & - & Aquisição do terreno \\
& - & Despesas legais \\
\hline Montagem do empreendimento & - & Projeto \\
& - & Aprovações \\
& - & Incorporações \\
& - & Planejamento \\
\hline Implantação & - & Custeio da produção \\
& - & Custos financeiros da produção \\
\hline Comercialização & - & Propaganda e promoção \\
(ou Locação) & - & Honorários p/ comercialização \\
\hline
\end{tabular}

Tabela 1 - As etapas da implantação de um EEL e a demanda por recursos

A Figura 9 a seguir ilustra o encadeamento destas etapas: 


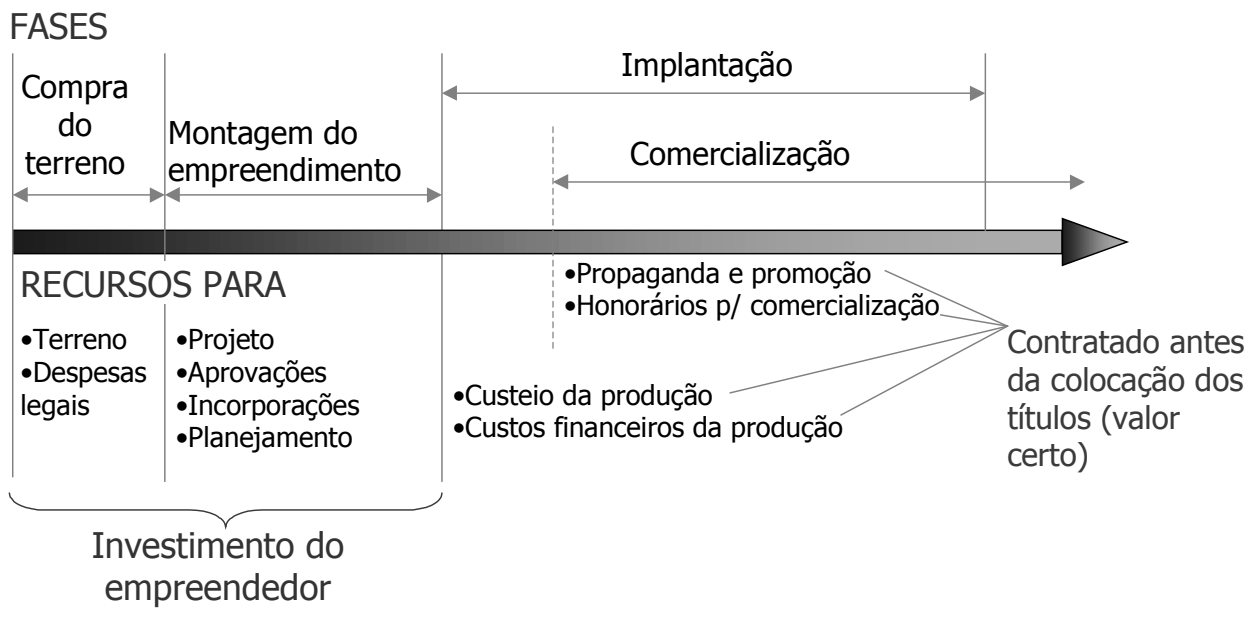

Figura 9 - Fases do ciclo de implantação e comercialização de um EEL e os recursos necessários

Em linhas gerais, o que geralmente ocorre é a montagem do negócio pelo próprio empreendedor, fazendo uso de recursos próprios e a posterior colocação de títulos suficientes para gerar recursos necessários para produção, inclusive custos financeiros e custos associados ao processo de gestão dos títulos (fiança, agentes para fiscalização e auditoria). Pode-se emitir títulos contra os valores já investidos, mas estes geralmente ficam de posse do empreendedor. Conforme o empreendimento vai sendo comercializado, ou a renda vai sendo gerada durante a operação do empreendimento, os recursos encaixados vão remunerando os títulos.

A Figura 10 abaixo ilustra a derivação de recursos da colocação dos títulos lastreados em ativos imobiliários: 


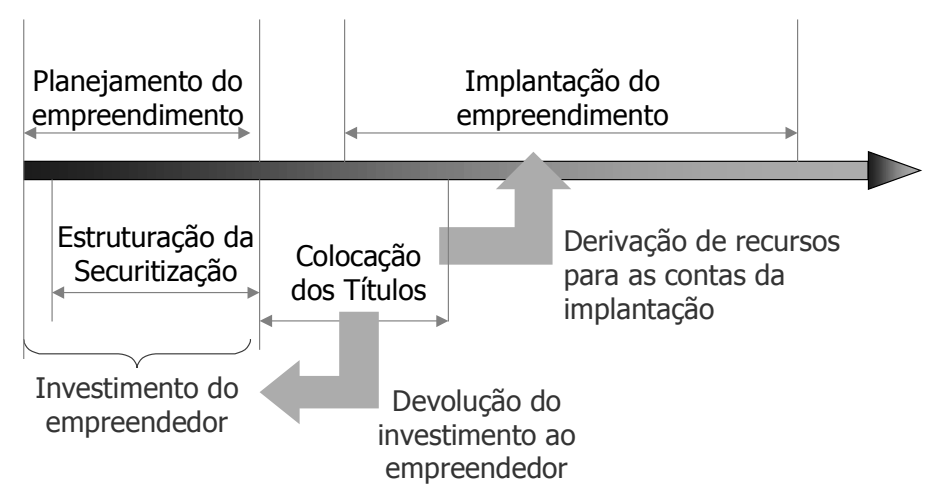

Figura 10 - Derivação de recursos da colocação dos títulos lastreados em ativos imobiliários (fonte: Unitas, 2003)

\section{10 Montagem de uma operação}

A rotina de ações para a montagem de uma estrutura de securitização segue os seguintes passos:

- ceder ativos do empreendedor para o ambiente de securitização (SPE, ou FII) em troca de títulos (ou quotas, no caso de FII) que servirão de vetor de securitização;

- emitir títulos (ou quotas) em formato atraente aos investidores;

- colocar os títulos (ou quotas) junto a investidores;

- implantar o empreendimento, nos casos em que os recursos foram captados com este objetivo, usando recursos de caixa gerados com a colocação dos títulos (ou quotas), em cumprimento dos contratos de implantação;

- receber o produto líquido dos ativos segregados, resultado da renda gerada no empreendimento;

- cumprir os pagamentos devidos aos investidores com o caixa gerado pela renda do empreendimento. 


\section{11 Formas de atraç̃o de investidores para o mercado de securitizacão de EELS}

A qualidade de uma operação de securitização de empreendimentos de base imobiliária está diretamente vinculada à qualidade do empreendimento, sua inserção de mercado e sua capacidade de geração e manutenção de renda ao longo do seu ciclo de vida, o que reforça a necessidade de conhecimento do mercado para que se tenha uma avaliação correta do investimento.

Por outro lado, a securitização de EEL tem o objetivo de trazer para o setor da construção civil recursos do mercado de capitais, onde os investidores não têm conhecimento pleno do setor. Desta forma, a necessidade de estruturas que colaborem para o aumento da confiabilidade do desempenho dos títulos de securitização se torna evidente.

Outro aspecto importante na ausência de um mercado secundário aquecido, como ocorre no Brasil, é a conformação dos títulos à necessidade dos investidores, de forma a proporcionar a saída do investidor em marcos previamente traçados por eles.

É neste contexto que são descritas a seguir algumas formas de atrair investidores para o mercado de securitização de EELs.

\subsubsection{Garantia de renda no período de implantação}

Como forma de atrair investidores, retirando do título a característica do EEL de imobilizar recursos sem retorno pelo ciclo de implantação do empreendimento, pode-se fazer a formatação de títulos com remuneração garantida pelo empreendedor até que o produto entre em operação. Este procedimento reforça o compromisso do empreendedor com a conclusão da obra, aportando mais segurança ao título de investimento. 
A Figura 11 ilustra esta modalidade de garantia, mostrando que no período de implantação o título fornece renda adicional garantida (RAG) pelo empreendedor, uma vez que, neste período, o EEL não é capaz de gerar renda. Após a implantação, os títulos são remunerados através dos resultados operacionais disponíveis $\left(\mathrm{ROD}_{\mathrm{i}}\right)$ gerados pelo EEL.

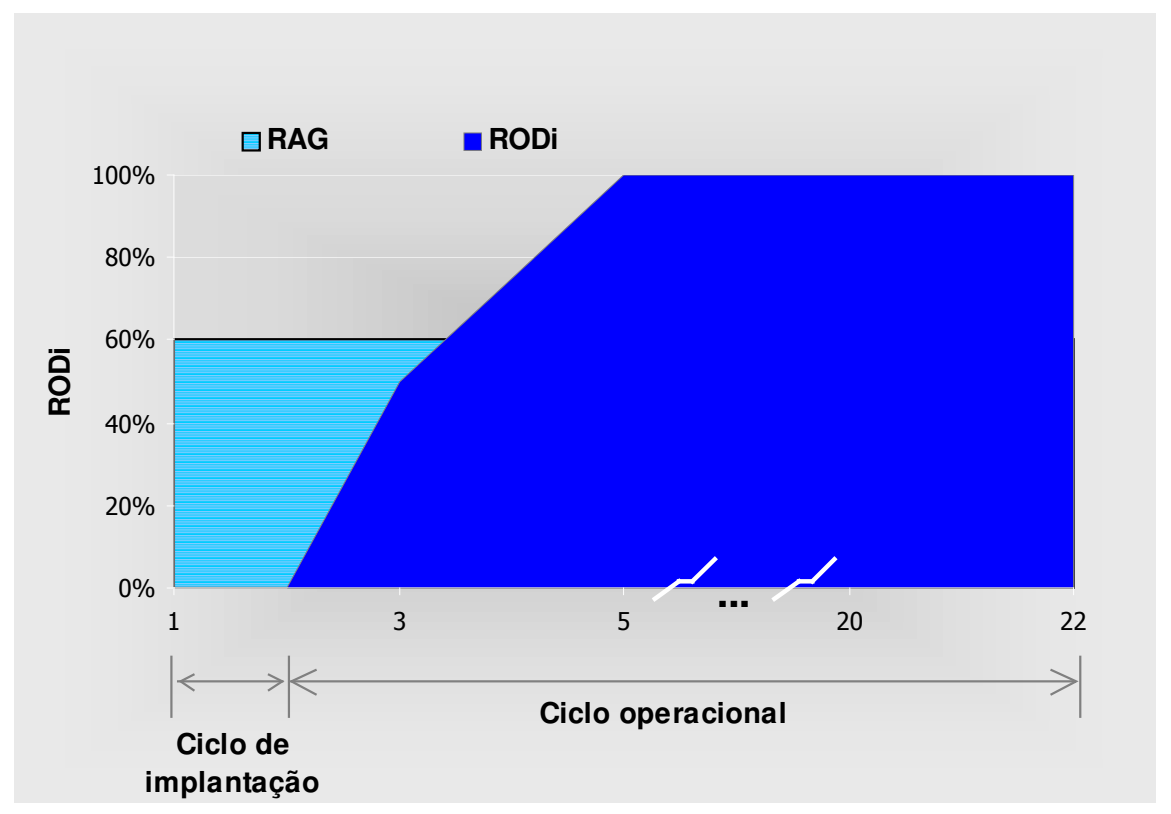

Figura 11 - Ilustração de fluxo de renda garantida pelo empreendedor e RODi distribuídos para os títulos de securitização de um EEL: proteção dos investidores através de remuneração no período de implantação

Usualmente, os investidores têm receio de aplicar recursos em empreendimentos em fase de implantação, já que há o risco de desvios de orçamento da construção e a possibilidade de não conclusão da obra. Além disso, nesta fase, os investidores desconhecem o grau de competitividade do EEL frente à concorrência, ou seja, a inserção de mercado nesta etapa ainda é uma premissa não concretizada, afastando os investidores de perfil mais conservador.

Neste sentido, a garantia de renda no ciclo de implantação do empreendimento é uma forma de atrair investidores pela via do comprometimento do empreendedor com o produto que coloca no mercado. 
Do ponto de vista do investidor, o investimento foi feito em um ativo que já lhe aufere renda, não tendo imobilizado recursos para auferir renda apenas no futuro.

Para o empreendedor, apesar do aumento dos custos com a captação de recursos pela securitização, ele atrai investidores, garantindo o aporte de capital para a etapa do ciclo de vida do empreendimento que demanda mais recursos. Além disso, o empreendedor aumenta a alavancagem, uma vez que recebe, antecipadamente, recursos com a promessa de rendimentos atrelados à taxa de atratividade percebida para o ciclo operacional, sensivelmente inferior àquela arbitrada pelo empreendedor para o ciclo de implantação.

É importante colocar que os títulos que oferecem tal garantia não oferecem proteção aos riscos inerentes ao negócio de EEL, ou seja, a garantia de renda durante a implantação não mitiga os riscos de desvio de orçamento e de inserção de mercado. O objetivo de tal garantia é mostrar a confiança que o empreendedor tem na entrega de seu produto e atrair investidores que prezem por tal atitude, ou que queiram uma remuneração imediata para seu investimento.

\subsubsection{Garantia de renda mínima no início do ciclo operacional}

Da mesma forma que a garantia de renda no período de implantação, o empreendedor pode oferecer a garantia de uma renda mínima no início do ciclo operacional, mitigando as incertezas de rentabilidade do título atreladas à velocidade de inserção do produto no mercado.

Nesta modalidade, pode-se definir um período de inserção de mercado após a implantação do empreendimento (em torno de 4 anos) para o qual o empreendedor garante uma renda mínima ao investidor. Desta forma, caso o EEL apresente uma velocidade de inserção de mercado inferior à esperada, os investidores têm a proteção do empreendedor. 
A Figura 12 ilustra graficamente esta modalidade de garantia, mostrando que, conforme o EEL tem sua inserção de mercado e incrementa gradativamente sua geração de renda, o empreendedor aporta menos recursos para garantir a rentabilidade dos títulos lastreados no empreendimento.

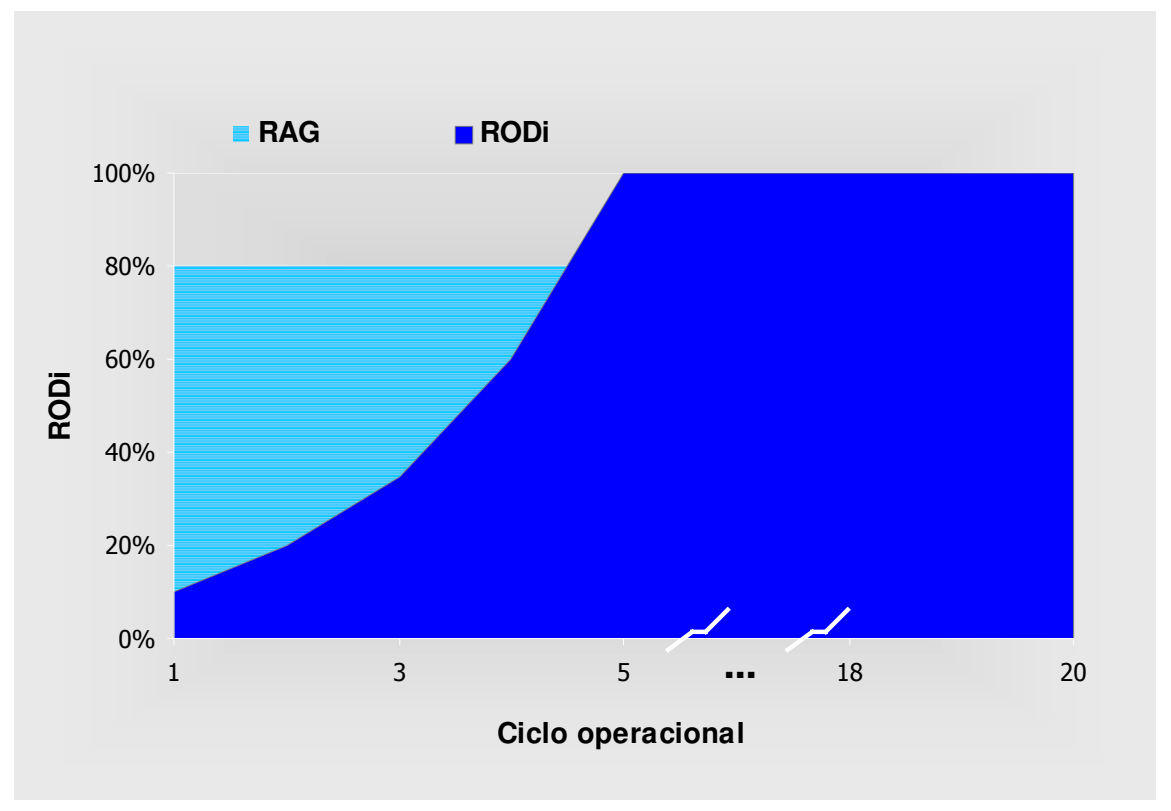

Figura 12 - Ilustração de fluxo de renda garantida pelo empreendedor e RODi distribuídos para os títulos de securitização de um EEL: proteção dos investidores através de remuneração no período de inserção de mercado

Quando há garantia de renda mínima no período de inserção no mercado, a análise de valor do papel de securitização com garantia de renda, considera o fluxo de RODi e o da renda adicional paga pelo empreendedor, gerando um incremento no valor arbitrado para o título.

Nestes casos, o investimento está ancorado em ativos de natureza distinta: [i] no potencial de geração de renda do EEL, e [ii] na renda adicional garantida (RAG), ou seja, na promessa de pagar do empreendedor, que se extingue e, portanto, perde valor conforme é cumprida. "Esse valor perdido não há nada que garanta que se incorpora ao bem imobiliário adiante. Em princípio, a incorporação só acontecerá se o desempenho do EBI, ou não exigir o pagamento 
da renda garantida, ou crescer, após o pagamento da renda garantida, a ponto de se valorizar para compensá-la" (ROCHA LIMA p.3, 2006).

Em síntese, apesar de mitigar o impacto dos riscos de inserção de mercado, esta é uma proteção aparente à manutenção do valor do título, uma vez que os títulos lastreados em empreendimentos que não tenham a inserção de mercado conforme a projeção feita quando da sua análise de valor, sofrerão desvalorização.

Rocha Lima (2006) aponta um risco de um proprietário de EEL emular, por exemplo, um FII lastreado neste imóvel, retro alugando-o, por entender barato se financiar na taxa de renda que representa a atratividade para a colocação das quotas. Neste cenário, este agente pode aceitar pagar um aluguel maior em relação ao mercado para aumentar o valor percebido na quota do FII e, em determinado momento, romper, ou encerrar o contrato de locação.

Como não há contrato de aluguel que não possa ser rompido, é importante que os papéis de securitização tenham sua análise de valor marcada a mercado, levando em conta os riscos de vazio e de flutuações no aluguel, e não considerando contratos de locação aparentemente livres de risco, uma vez que estes aportam valor sem lastro aos papéis da securitização.

\subsubsection{Securitizacão com emissão de títulos seniores protegidos por títulos subordinados}

Uma outra possibilidade de mitigação de riscos é a criação de títulos seniores protegidos por títulos subordinados que absorvem grande parte dos riscos. Esta prática é adotada também na securitização de recebíveis imobiliários através da estrutura de subordinação, fazendo-se emissões de títulos com séries distintas, onde o recebimento de recursos para os títulos de determinadas emissões é dependente do recebimento de recursos de outras, fazendo com que o desempenho de uma série seja depende do desempenho da série superior. 
A Figura 13 apresenta de forma hipotética essa solução, supondo um fluxo de retorno homogêneo do EEL objeto da securitização. Desta forma, divide-se o fluxo dos RODi identificando qual é a parcela sujeita a risco e qual é a parcela sobre a qual tem-se confiabilidade suficiente para garantir a renda do título com um grau de segurança que satisfaça o potencial investidor. O objetivo desta separação do fluxo é submeter aos investidores os títulos lastreados na parcela protegida do fluxo (títulos seniores), mantendo com o empreendedor, responsável pela qualidade do empreendimento por deter o conhecimento do mercado, títulos lastreados na parcela arriscada (títulos subordinados).

Quanto maior for a relação parcela arriscada/ parcela protegida, maior é a segurança dada ao investidor sobre o retorno dos títulos.

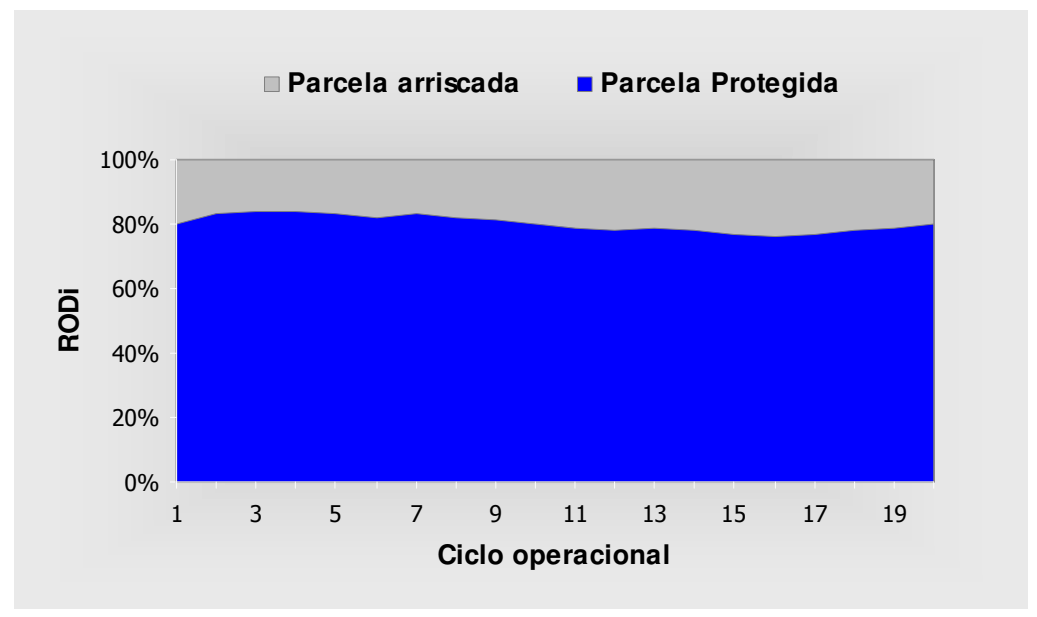

Figura 13 - Ilustração de fluxo de RODi distribuídos entre títulos de securitização de um EEL: mitigação de riscos via identificação da parcela do fluxo sujeita a riscos.

Esta modalidade de garantia oferece aos investidores uma proteção real ao risco de desempenho do EEL, já que os títulos subordinados protegem os demais títulos ao longo de todo ciclo de vida do empreendimento, e não em uma etapa específica. 
É importante frisar que a emissão de títulos privilegiados em relação a outros só é possível em ambiente de SPE, uma vez que os FII, por serem condomínios de investidores, não permitem esta prática.

\subsubsection{Conformacão do fluxo de retorno dos títulos segundo as necessidades dos investidores-chave}

Alguns investidores têm exigências específicas com relação ao prazo no qual intencionam manter determinado ativo na carteira, o que remete à preocupação com a liquidez do investimento.

No Brasil, a ausência de um mercado secundário que possibilite trocas e saídas rápidas de posições montadas em títulos de securitização de EELs, leva os empreendedores e colocadores a criar títulos que atendam a demanda específica de cada tipo de investidor identificado.

A Figura 14 apresenta, de forma hipotética, a repartição do fluxo de RODi do EBI de forma a lastrear diferentes perfis de títulos que atendam aos investidores.

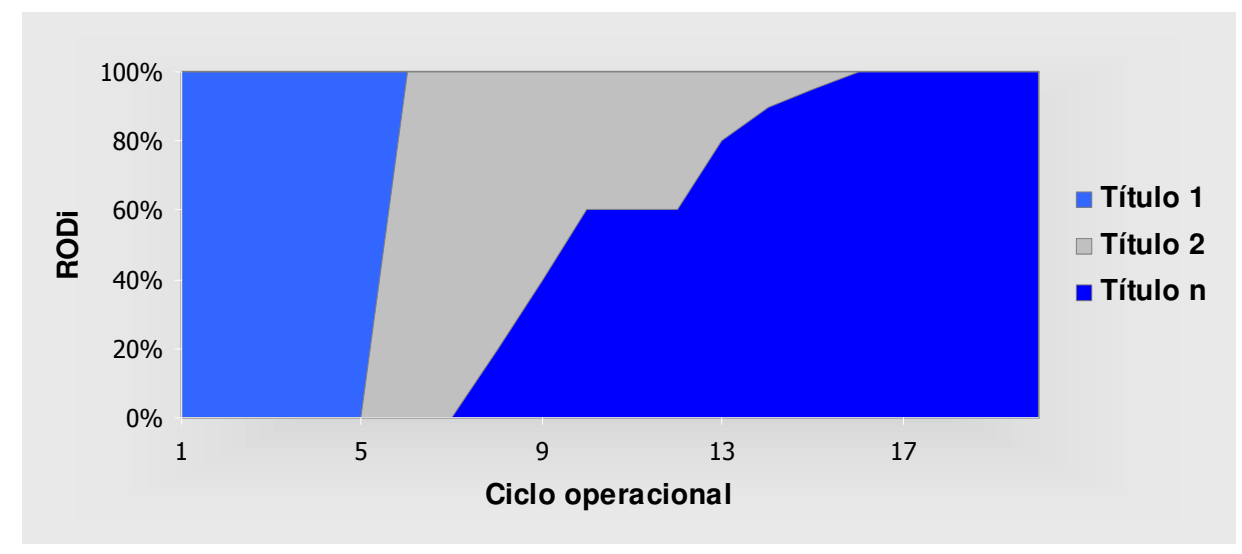

Figura 14 - Ilustração de fluxo de RODi distribuídos entre títulos de securitização de um EEL: conformação do retorno dos títulos às necessidades do investidor. 
Com esta estruturação pode-se desenhar títulos adequados às necessidades dos fundos de pensão, por exemplo, já que os mesmos são os principais investidores em EELs no mercado brasileiro. Além disso, estas instituições tem necessidade de aplicar recursos para garantir a renda de seus beneficiados, perfil de investimento no qual os EELs se enquadram.

Desta forma, conforme a estrutura de contribuintes e beneficiados de um fundo de pensão é possível construir títulos que gerem renda por determinado período, após o qual possam ser resgatados pela instituição. Novamente, esta estrutura que permite o resgate dos títulos só é possível no ambiente da SPE.

\subsubsection{Garantias dependentes de terceiros}

Outros tipos de reforços que podem ser utilizados são baseados em proteções oferecidas por terceiros, tais como: [i] carta de fiança, prestada por um terceiro, usualmente uma instituição financeira, com o objetivo de cobrir total ou parcialmente apenas alguns dos riscos existentes na operação, e [ii] seguros para garantir riscos da implantação do empreendimento.

Estas garantias são oferecidas para os investimentos feitos no ciclo de implantação no qual o investidor aplica seus recursos sem que haja a concretização do empreendimento propriamente dito e, por esse motivo, o mesmo não possa ser dado em garantia fiduciária.

Estas são proteções efetivas, pois garantem aos investidores a recuperação do valor investido, caso o empreendimento não seja concluído.

Os seguros-garantia necessitam da intermediação de uma seguradora e o prêmio só é pago aos investidores após o julgamento da própria seguradora com relação ao não cumprimento contratual. Já a carta de fiança é de execução mais simples e, apesar de ser fornecida por instituições bancárias, não necessita do julgamento da mesma. 


\subsection{6 $\underline{\text { A importância das grandes marcas }}$}

Além dos itens abordados acima, ressalta-se aqui a importância que grandes marcas têm em um mercado de securitização, uma vez que conferem credibilidade às emissões, tranqüilizando o investidor e reduzindo assim suas exigências com relação a itens custosos (como por exemplo, seguros e garantias) que oneram o processo de securitização.

O desenvolvimento da securitização no mercado americano foi pautado nas grandes marcas do setor, que aportavam sua experiência e conhecimento de mercado aos empreendimentos.

Grandes empresas com saúde financeira comprovada têm grande poder de atração sobre os investidores inexperientes no mercado. Estes investidores preferem uma remuneração menor oferecida por um título atrelado a uma grande empresa do setor, à uma remuneração mais agressiva de títulos vinculados a empresas desconhecidas.

\section{12 O mercado norte-americano como paradigma}

Nos Estados Unidos, o ambiente no qual a securitização é promovida chama-se REIT (acrônimo de Real Estate Investiment Trusts) ${ }^{46}$. Os REITs são sociedades anônimas que aglutinam capital de vários investidores para adquirir propriedades geradoras de renda ou para promover financiamentos para a carteira hipotecária de imóveis. Os investidores são donos do REIT pela via dos títulos que adquirem, sendo que estes títulos são negociados, na sua grande maioria, nas bolsas de valores. Desta forma, ao se investir em um REIT, adquire-se parte de um diversificado portfólio de investimentos imobiliários.

O mercado norte-americano é exemplo vivo do crescimento do mercado de securitização, lá a capitalização dos REITs estava em US\$ 89 bilhões em 1996, tendo encerrado o ano de 1999 
com pouco mais de US\$ 124 bilhões, já alcançando um patamar de quase US\$ 308 bilhões em dezembro de 2004 (NAREIT). A Figura 15 abaixo, ilustra a evolução mencionada. Esse grau de maturidade é obtido pelo aquecimento do mercado secundário que aumenta as possibilidades de investimentos, através da melhor adaptação dos títulos às necessidades dos investidores no que tange ao prazo de retenção de seus recursos.

O aumento de capitalização abrupto após 2001 pode ser, em parte, atribuído à descrença generalizada no mercado de capitais. Nesta época, a NASDAQ ${ }^{47}$ apresentou queda expressiva em virtude da falência de inúmeras empresas de tecnologia denominadas "ponto com", gerando perdas substanciais aos portfólios de muitos investidores.

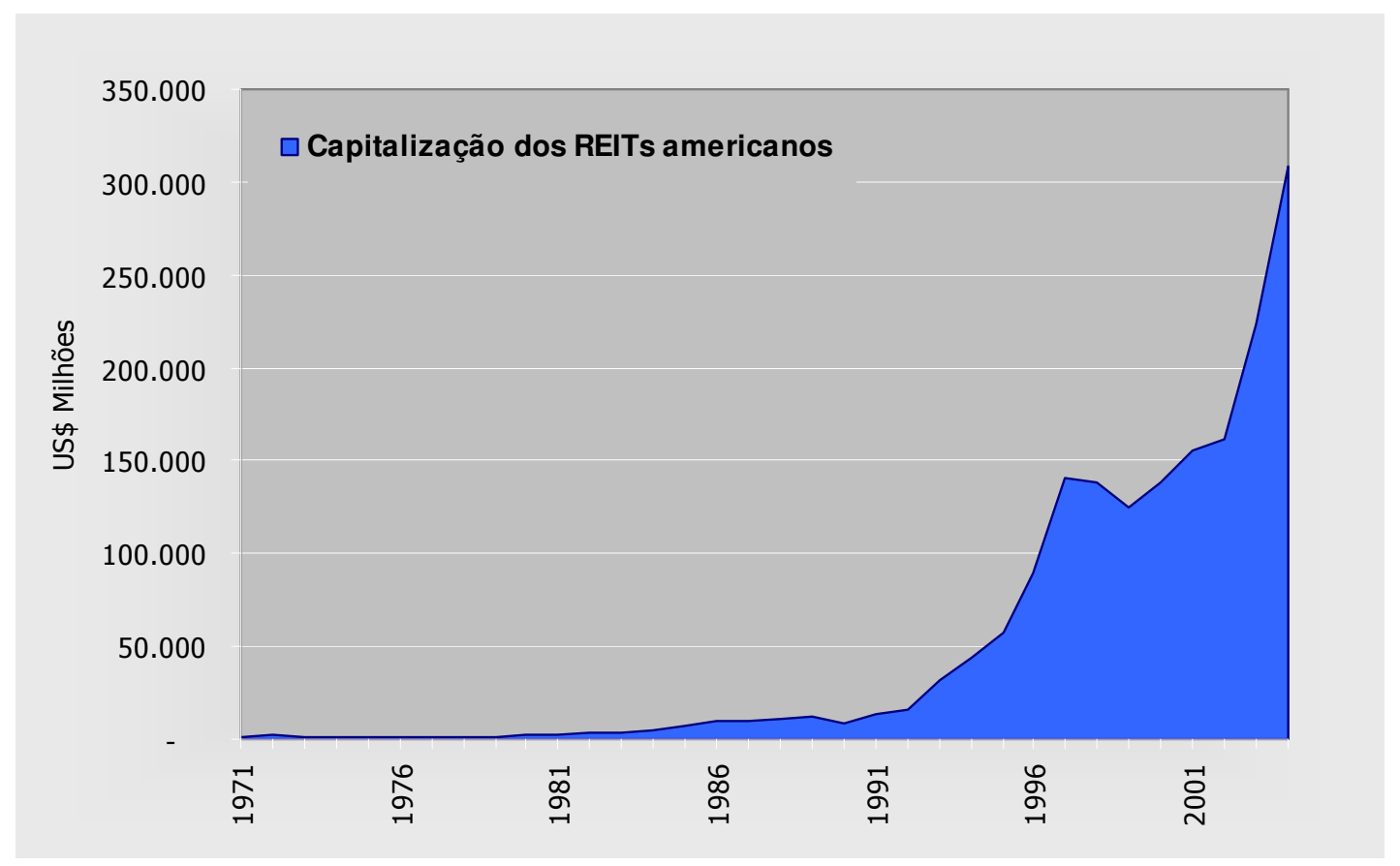

Figura 15 - Evolução da capitalização dos REITs americanos de 1971 a $2004^{48}$ (fonte: NAREIT)

\footnotetext{
${ }^{46}$ Estrutura muito próxima a da SPE brasileira.

${ }^{47}$ National Association of Securities Dealers Automated Quotation System. A Nasdaq é uma bolsa eletrônica que funciona no mercado norte-americano, ligando diretamente compradores e vendedores.

48 A capitalização é medida em EMC (Equity Market Capitalization), ou seja, multiplicando-se o número de títulos em circulação no mercado pelos respectivos valores a que os mesmos são negociados no momento da medida. Desta forma a EMC é a medida do tamanho de um mercado de títulos em determinado momento.
} 
Segundo Rocha Lima (2001), em função das dimensões do mercado americano, a aplicação de recursos, mesmo sendo conservadora, apresenta um elevado padrão de liquidez, pois a pulverização destes empreendimentos permite trocas intensas e rápidas, uma vez que se multiplicam as oportunidades de vender e comprar. Assim sendo, o investimento já se apresenta como de horizonte mais curto do que o do empreendimento, permitindo aos investidores decidir tendo em vista períodos de retenção do investimento mais curtos, porque a tendência é que o mercado possa oferecer boa liquidez às posições de investimento.

\subsubsection{Histórico}

"O formato atual de REIT foi criado em 1960 como resultado das emendas ao U.S. Internal Revenue Code ${ }^{49}$. Essas emendas foram introduzidas para criar mecanismos de acesso e de participação dos pequenos poupadores em grandes empreendimentos imobiliários que antes eram disponíveis somente para grandes corporações e para investidores sofisticados, os quais detinham participação direta como proprietários dos imóveis. A característica-chave dos REITs norte-americanos é a isenção de impostos federais sobre a distribuição de ganhos aos acionistas" (PARK p.52, 1997).

Park (1997) ressalta que para se qualificar como REIT e gozar da isenção do imposto de renda, alguns requisitos básicos devem ser atendidos, tais como:

- A administração deve ser feita por uma diretoria eleita, ou por agentes fiduciários.

\footnotetext{
${ }^{49}$ Correspondente ao Código Tributário Brasileiro.
} 
- A estrutura deve ser a de uma sociedade anônima, companhia fiduciária ou associações similares, tendo tratamento de sociedade anônima para efeitos fiscais.

- As ações da companhia devem estar desimpedidas e livres para negociação, independentemente do REIT ser uma companhia aberta, ou fechada.

- A pulverização deve ser garantida pela presença de mais de 100 acionistas (acionistas ou detentores de títulos) e pela restrição de que cinco ou menos pessoas não podem deter mais de $50 \%$ dos títulos do REIT.

- Pelo menos $75 \%$ do ativo do REIT deve ser investido em imóveis ou em créditos imobiliários, devendo gerar no mínimo $75 \%$ das receitas através de rendimento de exploração de imóveis, ou de juros de crédito imobiliário. Além disso, com o intuito de desestimular a especulação imobiliária por parte dos REITs, as receitas geradas pela venda de imóveis com menos de 4 anos de propriedade ou pela venda dos títulos com menos de 6 meses de carteira não devem ultrapassar $30 \%$ do total de receitas.

- Mais de $90 \%$ do resultado tributável deve ser distribuído para os detentores dos títulos.

\subsubsection{Tipos de REIT}

- Equity REIT: são os REITs mais comuns, que investem patrimonialmente, detendo a propriedade dos imóveis. Eles podem ser diversificados ou especializados, em função da diversidade de sua carteira em termos de tipos de imóveis (shopping centers, escritórios, hospitais etc.) e/ou localização geográfica.

- Mortgage REIT: são os que investem em carteira de financiamento imobiliário, tanto via títulos gerados por ele mesmo, quanto pelos adquiridos no mercado secundário. Neste 
caso, o rendimento dos títulos ocorre através dos juros dos créditos imobiliários por eles financiados.

- REIT Híbrido ou Combinado: são os que apresentam carteira de ativos composta tanto por propriedades imobiliárias, quanto por créditos imobiliários de diferentes tipos de imóveis.

\section{6. $13 \underline{O \text { mercado brasileiro }}$}

Segundo Rocha Lima (2001a) o mercado brasileiro apresentava em 2001 perto de R\$ 1,4 bilhões de posições em Fundos de Investimento Imobiliário ${ }^{50}$ (CVM apud Rocha Lima, 2001a) e ao redor de $\mathrm{R} \$ 2,0$ bilhões em Títulos de Investimento com Lastro em Ativos, securitizando empreendimentos de base imobiliária, com posições de investimento na sua grande maioria concentradas em investidores institucionais, ou grupos de investimento, iniciando-se um caminho de pulverização, que atinge ao redor de $\mathrm{R} \$ 0,2$ a $\mathrm{R} \$ 0,3$ bilhões.

Ainda segundo o mesmo autor, a liquidez dos investimentos proporcionada por mercados de securitização aquecidos não é uma característica intrínseca do investimento, já que o balizador dos empreendimentos de base imobiliária é um horizonte de ciclo operacional longo (cerca de 20 anos). Portanto, em mercados nos quais as trocas não são tão intensas, como é o caso do mercado brasileiro, porque o volume de mercado securitizado ainda não é expressivo e pulverizado, as análises sobre a qualidade do investimento devem considerar todo o ciclo operacional, uma vez que a perspectiva de liquidez não é tão presente.

\footnotetext{
${ }^{50}$ Hoje este número é de quase R $\$ 2,4$ bilhões.
} 


\subsubsection{Evolucão do investimento em EBI no mercado brasileiro}

Rocha Lima ${ }^{36}$ resume a evolução do investimento em EBI no mercado brasileiro ressaltando as formas de investimento praticadas pelas poupanças familiares, por grandes investidores e por investidores institucionais da seguinte maneira:

- Poupança das famílias. Historicamente, na cultura brasileira, as famílias montam sua poupança em imóveis residenciais para locação. Na década de 70, esta carteira de investimentos foi ampliada através de pequenos imóveis em edifícios de escritórios, seguidos, na década de 80, por pequenas unidades hoteleiras (flats) e, posteriormente, com a chegada do século XXI pela aplicação em fundos de investimento imobiliário.

- Grandes investidores. Na década de 80, investiam especialmente em grandes lajes de escritórios. Enquanto que, na década de 90, acompanhando o "boom” dos flats na cidade de São Paulo, há uma grande concentração de investimentos em pequenas unidades hoteleiras, possibilitando a estes investidores a montagem de portfólios diversificados. Já no século XXI, estes investidores também usufruem dos FIIs.

- Investidores Institucionais. Na década de 80, assim como os grandes investidores, investem especialmente em grandes lajes de escritórios, além de shopping centers e alguns REITs, e, com a chegada do século XXI englobam em seus portfólios FIIs e hotéis.

Para o futuro, o autor aponta para a superação da estratégia de investimento em hotéis e de aquisição de pequenas unidades, como é o caso dos imóveis residenciais para locação, dos pequenos imóveis em edifícios de escritórios e dos flats.

No médio prazo o autor reconhece que serão mantidos os investimentos em grandes lajes de escritórios e em shopping centers, ressaltando que as estratégias predominantes no longo prazo são as de aplicação em REITs e em FIIs. 
A velocidade de migração para estes investimentos mais evoluídos é função do redirecionamento das estratégias de empreender, uma vez que a timidez na oferta deste tipo de estrutura de investimento não produz a escala exigida para conferir agressividade ao mercado secundário que dá confiabilidade ao investidor por facilitar a aferição de valor, a entrada e a saída do mercado atendendo às necessidades específicas de cada investidor.

O mercado brasileiro mantém a leitura do processo de securitização como sendo a reorganização da forma de investir num determinado EBI. Já, no mercado americano, os REITs agregam grandes portfólios e se especializam por segmento de mercado ${ }^{51}$ e por região geográfica, possibilitando uma sensível diluição dos riscos para os investidores interessados.

\subsubsection{O principal investidor no mercado brasileiro}

No Brasil, o sistema oficial de previdência oficial não tem sido capaz de proporcionar proteção à qualidade de vida dos trabalhadores aposentados. Assim, seguindo o modelo de países do chamado Primeiro Mundo (Estados Unidos, Alemanha e Japão), foi criada em 1977 a previdência privada complementar.

A Lei 6.435 de 15 de julho de 1977 dispõe sobre a constituição, a organização e o funcionamento dos fundos de pensão, diferenciando dois tipos de previdência complementar: [i] entidades fechadas, específicas dos empregados de uma empresa ou grupo de empresas e [ii] entidades abertas, geralmente administradas por bancos e seguradoras, aonde qualquer pessoa pode aderir custeando o seu plano de benefícios. As entidades fechadas não visam a distribuição de lucros e recebem contribuições do trabalhador participante e do empregador, enquanto que as entidades abertas podem ter fins lucrativos.

\footnotetext{
${ }^{51}$ Segmentação por tipo de EBI: escritórios, shopping centers etc.
} 
Detentores de uma grande massa de recursos, os fundos de pensão no Brasil têm sido historicamente grandes investidores no mercado de ações e grandes financiadores do mercado de base imobiliária, provendo recursos para shopping centers e edifícios comerciais.

Segundo a Secretaria de Previdência Complementar (SPC), em julho de 2005 o ativo total das entidades fechadas de previdência complementar atingia a cifra de 294,5 bilhões de Reais, sendo que $37 \%$ correspondem a entidades privadas e $63 \%$ a públicas. Deste montante, apenas 4,2\% foram classificados como investimentos imobiliários.

Os fundos de pensão fazem parte do Sistema Financeiro Nacional (SFN) na qualidade de operadores, sendo fiscalizados e supervisionados pela SPC, cabendo ao Conselho de Gestão da Previdência Complementar (CGPC), órgão colegiado integrante da estrutura do Ministério da Previdência Social, a função de órgão normativo.

Além disso, cabe ao Conselho Monetário Nacional (CMN) a tarefa de determinar as diretrizes referentes às aplicações dos recursos dos fundos de pensão. Essa regulamentação se dá por meio de resoluções que estabelecem limites máximos de aplicação em de diferentes classes de ativos, a saber: renda fixa, renda variável, imóveis e empréstimos e financiamentos.

Nos últimos anos, a legislação referente aos investimentos feitos pelos fundos de pensão tem passado por várias mudanças, seja para permitir a aplicação em novos instrumentos financeiros, seja para estabelecer a adoção de determinados procedimentos ou instrumentos de gestão de riscos. No que diz respeito à aplicação de recursos em imóveis, o limite de recursos alocados no segmento é de 14\% em 2003, 2004 e 2005, 11\% em 2006, 2007 e 2008 e 8\% a partir de 2009. Nota-se, portanto, que a disponibilidade de recursos a serem aplicados diretamente em imóveis sofrerá reduções paulatinas. 
Neste cenário, a securitização possibilita a emissão de títulos de dívida, fazendo com que seja possível captar recursos e direcioná-los para EELs sem consumir o limite de enquadramento. No entanto, a emissão destes títulos descaracteriza o investimento em EELs, desvinculando a rentabilidade e os riscos destes daquela auferida nos títulos. O risco atrelado a tais títulos passa a ser o de inadimplência e não o do desempenho do empreendimento.

Os títulos securitizados possibilitam aos fundos diluir riscos, uma vez que não exigem a concentração de investimentos em um único imóvel. No passado, os fundos conseguiam esta diluição adquirindo milhares de pequenos imóveis residenciais e comerciais dos quais extraiam renda, arcando assim com elevados custos de administração.

A Tabela 2 abaixo apresenta a evolução da composição da carteira dos fundos de pensão, mostrando que os mesmos operam atualmente abaixo do limite estabelecido pela legislação e que houve, nos últimos anos, uma redução das aplicações feitas em imóveis e um aumento das aplicações em renda fixa, como ilustrado na Figura 16. Atribui-se esta redução à manutenção de altas taxas de juros, fazendo crer que existem outras opções de aplicação mais atraentes a este investidor. 


\begin{tabular}{|c|c|c|c|c|c|c|c|c|c|c|c|c|c|c|c|c|c|c|c|c|c|c|}
\hline \multirow{2}{*}{ Discriminação } & \multicolumn{2}{|c|}{ dez-95 } & \multicolumn{2}{|c|}{ dez-96 } & \multicolumn{2}{|c|}{ dez-97 } & \multicolumn{2}{|c|}{ dez-98 } & \multicolumn{2}{|c|}{ dez-99 } & \multicolumn{2}{|c|}{ dez-00 } & \multicolumn{2}{|c|}{ dez-01 } & \multicolumn{2}{|c|}{ dez-02 } & \multicolumn{2}{|c|}{ dez-03 } & \multicolumn{2}{|c|}{ dez-04 } & \multicolumn{2}{|c|}{ dez-05 } \\
\hline & Valor & $\%$ & Valor & $\%$ & Valor & $\%$ & Valor & $\%$ & Valor & $\%$ & Valor & $\%$ & Valor & $\%$ & Valor & $\%$ & Valor & $\%$ & Valor & $\%$ & Valor & $\%$ \\
\hline 01. Ações & 16.923 & 29,5 & 22.162 & 30,9 & 24.724 & 28,5 & 17.465 & 19,2 & 30.259 & 26,3 & 30.669 & 23,6 & 28.614 & 18,5 & 26.684 & 15,8 & 40.968 & 19,0 & 51.188 & 20,0 & 59.975 & 20,3 \\
\hline 02. Imóveis & 8.548 & 14,9 & 9.225 & 12,9 & 9.038 & 10,4 & 9.684 & 10,7 & 10.110 & 8,8 & 10.460 & 8,0 & 10.554 & 6,8 & 11.330 & 6,7 & 11.601 & 5,4 & 11.565 & 4,5 & 11.836 & 4,2 \\
\hline 03. Depósito a prazo & 8.367 & 14,6 & 6.891 & 9,6 & 6.623 & 7,6 & 8.818 & 9,7 & 5.313 & 4,6 & 4.145 & 3,2 & 4.822 & 3,1 & 3.808 & 2,3 & 2.680 & 1,2 & 2.284 & 0,9 & 3.340 & 1,1 \\
\hline $\begin{array}{l}\text { Fundos de } \\
\text { 04. investimento - RF }\end{array}$ & 6.826 & 11,9 & 12.064 & 16,8 & 16.729 & 19,3 & 20.648 & 22,8 & 36.423 & 31,6 & 47.710 & 36,7 & 62.411 & 40,4 & 69.089 & 41,0 & 96.343 & 44,6 & 119.101 & 46,6 & 137.098 & 46,4 \\
\hline $\begin{array}{l}\text { Fundos de } \\
\text { 05. investimento - RV }\end{array}$ & ND & & 1.832 & 2,6 & 9.302 & 10,7 & 9.214 & 10,2 & 14.066 & 12,2 & 14.881 & 11,4 & 16.232 & 10,5 & 20.067 & 11,9 & 21.536 & 10,0 & 25.908 & 10,1 & 30.772 & 10,4 \\
\hline $\begin{array}{l}\text { Empréstimo a } \\
\text { 06. participantes }\end{array}$ & 1.067 & 1,9 & 1.592 & 2,2 & 1.623 & 1,9 & 1.740 & 1,9 & 1.805 & 1,6 & 2.279 & 1,8 & 2.742 & 1,8 & 3.190 & 1,9 & 3.992 & 1,8 & 4.883 & 1,9 & 5.650 & 1,9 \\
\hline $\begin{array}{l}\text { Financiamento } \\
\text { 07. imobiliário }\end{array}$ & 3.328 & 5,8 & 3.688 & 5,1 & 3.923 & 4,5 & 4.021 & 4,4 & 3.868 & 3,4 & 3.797 & 2,9 & 3.848 & 2,5 & 3.438 & 2,0 & 3.365 & 1,6 & 3.015 & 1,2 & 2.483 & 0,8 \\
\hline 08. Debêntures & 2.992 & 5,2 & 3.446 & 4,8 & 3.384 & 3,9 & 3.229 & 3,6 & 2.892 & 2,5 & 2.660 & 2,0 & 3.201 & 2,1 & 3.733 & 2,2 & 3.707 & 1,7 & 3.467 & 1,4 & 3.428 & 1,2 \\
\hline 09. Títulos públicos & 2.557 & 4,4 & 4.115 & 5,7 & 3.240 & 3,7 & 5.918 & 6,5 & 7.307 & 6,3 & 8.588 & 6,6 & 17.513 & 11,3 & 22.471 & 13,3 & 27.419 & 12,7 & 29.871 & 11,7 & 35.818 & 12,1 \\
\hline 10. Outros & 1.445 & 2,5 & 1.704 & 2,4 & 1.878 & 2,2 & 2.382 & 2,6 & 3.011 & 2,6 & 4.687 & 3,6 & 4.496 & 2,9 & 4.612 & 2,7 & 4.492 & 2,1 & 4.429 & 1,7 & 4.777 & 1,6 \\
\hline $\begin{array}{l}\text { Oper. } c / \\
\text { 11. patrocinadoras }\end{array}$ & 5.408 & 9,4 & 4.954 & 6,9 & 6.396 & 7,4 & 7.637 & 8,4 & 70 & 0,1 & 201 & 0,2 & 144 & 0,1 & 76 & 0,0 & 77 & 0,0 & 78 & 0,0 & 72 & 0,0 \\
\hline
\end{tabular}

Total

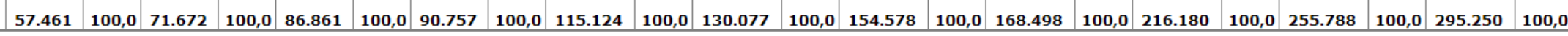
ND - Não disponivel

Tabela 2 - Composição da carteira dos fundos de pensão ao longo da última década (fonte: ABRAPP - Associação brasileira das entidades fechadas de previdência complementar) 


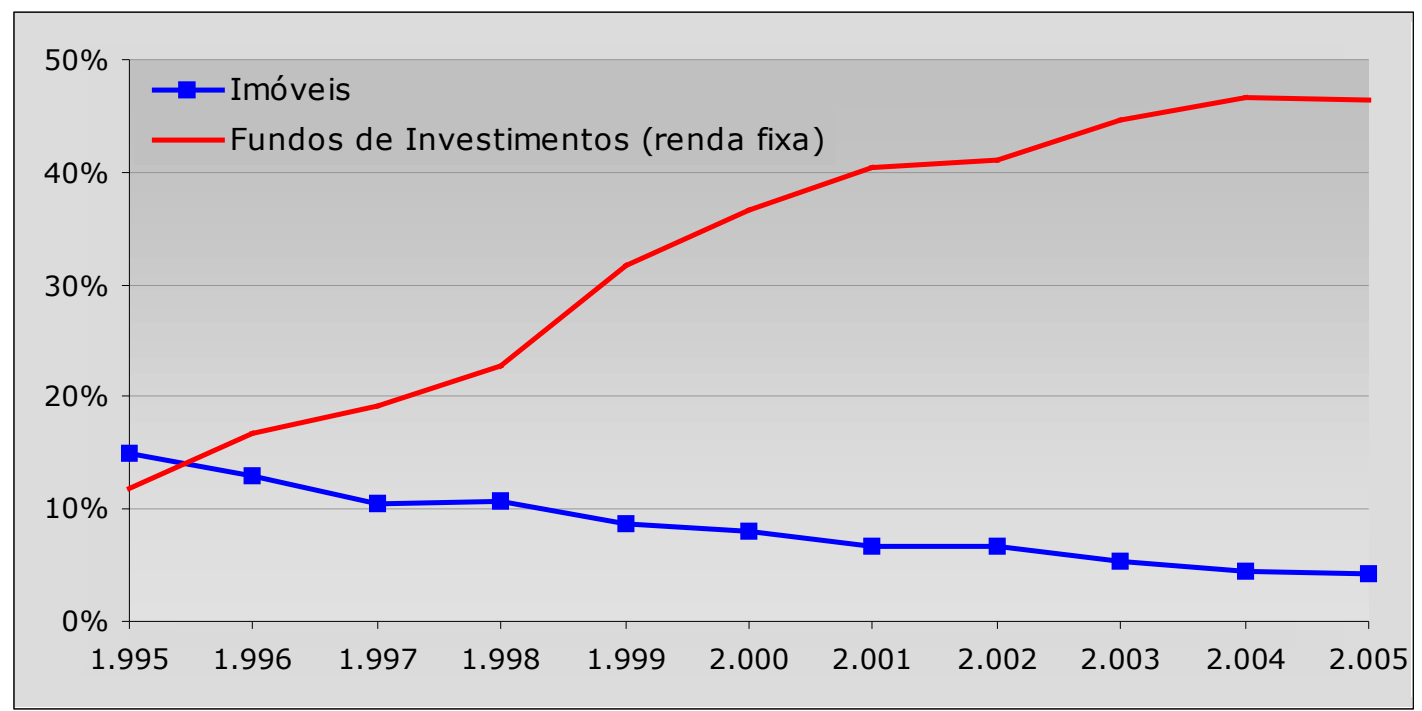

Figura 16 - Evolução da participação do investimento em imóveis e em renda fixa na carteira dos fundos de pensão (fonte de dados: ABRAPP)

Para ajudar a compreender o potencial de sucesso da securitização de EELs, atraindo os fundos de pensão, segue um resumo, feito por Park (1997), do perfil da demanda destas instituições enquanto investidores:

- Os fundos têm condição de investidor financeiro, ou seja, preferem não se envolver com atividades de empreendedor e podem investir em qualquer setor da economia desde que o binômio [risco x retorno] seja satisfatório.

- Além disso, seu patrimônio não pertence ao seu gestor. Na condição de um agente, o gestor tem a difícil tarefa de obter um alto rendimento com um risco quase nulo e ainda mantendo um determinado grau de liquidez. Isso faz com que ele valorize:

○ temporariedade,

○ controle da saída, 
○ estruturação que elimine risco, elaborada por especialistas,

○ diversificação,

- rentabilidade,

○ concentração da carteira de investimentos em imóveis para reduzir custo de administração, dando preferência para grandes empreendimentos.

- O setor imobiliário e os empreendimentos de base imobiliária são negócios nos quais os fundos se sentem mais confortáveis por estarem mais familiarizados.

- A tendência de queda de juros levará o Brasil a praticar juros compatíveis com os das economias mais desenvolvidas, fazendo com que os fundos busquem rendimentos baseados em empreendimentos e não em títulos do governo ou dos bancos que oferecerão rendimentos cada vez menores. 


\section{ATRATIVIDAde dos títUlos SECURITIZADOS}

No Brasil, o investimento em imóveis é feito, usualmente, por investidores com foco na geração de uma renda mensal perene para complementar o orçamento familiar, ou para sustentar a aposentadoria, sendo, portanto, um instrumento de poupança particular. Estes investidores podem ser de pequeno porte, proprietários de unidades; de porte médio, investindo em lajes de empreendimentos; ou de grande porte (investidores institucionais, como os Fundos de Pensão), investindo em empreendimentos inteiros.

Por outro lado, as altas taxas de juros reais vigentes no Brasil desde o Plano Real, fazem crer que investimentos cujo valor tenha apenas acompanhado a inflação, como acontece com os aluguéis de EELs, são investimentos de baixa qualidade. Fato constatado pela alteração do perfil da carteira dos fundos de pensão. Donde pode-se concluir, precipitadamente, que investimentos feitos em imóveis com o objetivo de obter uma renda perene são investimentos de baixa qualidade, havendo outras opções disponíveis no mercado que garantam o mesmo objetivo e uma maior remuneração ao investimento inicial.

Para confirmar tal hipótese, seria necessário comparar diferentes opções de investimento, mantendo o foco na necessidade de se obter uma renda mensal perene que será consumida pelo investidor e não reaplicada.

Neste contexto, e com o objetivo de ilustrar a competitividade dos investimentos em empreendimentos de base imobiliária usuais frente às demais opções disponíveis no mercado, Rocha Lima, Takaoka (2006) fazem a comparação das seguintes alternativas de investimento:

- empreendimento imobiliário, utilizado como base de comparação;

- caderneta de poupança; 
- investimentos financeiros, considerando a remuneração atrelada à taxa mensal de CDI;

- carteira de ações, considerando a remuneração atrelada ao desempenho da BOVESPA.

A comparação é baseada no comportamento histórico pós Plano Real, mais especificamente o comportamento do período de janeiro de 1995 a setembro de 2005, aqui referenciado como cicloR. Cada alternativa de investimento é analisada sob sua respectiva curva de evolução referencial no período.

A simulação dos autores atribui a cada uma das alternativas o mesmo volume de recursos na data inicial da análise, ou seja, tudo se passa com se na mesma data fosse perpetrado o mesmo volume de investimento em diferentes ativos. Admitindo-se ainda que o investidor faça saques mensais em sua carteira de investimento correspondente a renda líquida, depois do pagamento do imposto de renda, que alcançaria caso o investimento fosse feito num imóvel comercial para renda, como é o caso dos EELs.

Desta feita, a comparação se dá medindo-se o valor das carteiras de investimento ao final do cicloR.

\section{1 Carteira de referência}

Como já dito acima, a referência da comparação das diferentes carteiras será a receita mensal obtida em uma carteira imobiliária (portfólioR). Para definir este parâmetro as premissas e considerações feitas pelos autores serão elucidadas abaixo.

\section{Premissas:}

- Aplicação em jan/95: R \$ 1.000,00. 
- O valor da carteira de investimento evolui acompanhando o IGP-M. Para tal os autores fazem a seguinte ponderação: “o mercado estabiliza o valor dos imóveis comerciais, quando são atualizados e adequados funcionalmente, usando-se os recursos recolhidos ao FRA, o que acontece também com o valor dos aluguéis. Com respeito aos valores dos imóveis comerciais, as bases de dados paramétricos disponíveis indicam que ocorrem movimentos de valor descolados da curva do IGP-M em ciclos curtos, para cima e para baixo, fruto de situações particulares da economia e de uma natural desorganização da oferta. Entretanto, em ciclos longos, há uma tendência de que preços e aluguéis andem numa curva descolada para cima do IGP-M, o que confere ao cenário que utilizamos um grau de conservadorismo" (ROCHA LIMA; TAKAOKA p.4, 2006). Vale ressaltar a importância da gestão profissional do empreendimento que recolha o FRA, utilizando-o para promover atualizações e melhorias no empreendimento, de forma a mantê-lo competitivo. Neste sentido, pode-se citar como exemplo o centro de convenções do World Trade Center na Marginal Pinheiros, totalmente implantado com recursos do FRA $(\text { informação verbal })^{52}$.

- Renda de aluguel: $1,13 \%$ do valor investido. Arbitrado pelos autores como padrão de atratividade do segmento de mercado com base na média verificada numa amostra de 169 imóveis comerciais leiloados por bancos brasileiros de primeira linha, que atrelaram à venda um contrato de locação de $10 \operatorname{anos}^{53}$. Esta renda apresenta reajustes anuais pelo

\footnotetext{
52 Informação fornecida pelo Prof. Dr. João da Rocha Lima Jr. em São Paulo, em 2006

${ }^{53}$ Os leilões de imóveis comerciais dos bancos, na sua maioria ocupados por agências bancárias, visam atender a necessidade de alinhamento estratégico das instituições financeiras com os princípios básicos do Acordo da Basiléia e as Resoluções 2.099 e 2669, de 17/08/94 e 28/02/96, respectivamente, que definem índices máximos de imobilização sobre o patrimônio líquido das instituições financeiras. A definição do Banco Central do Brasil (BACEN) é de que o Ativo Imobilizado corresponda a no máximo $60 \%$ do Patrimônio Líquido, em junho/02, diminuindo este percentual para 50\% em dezembro/02.
} 
IGP-M, sofrendo assim queda do seu poder de compra dentro do ciclo anual. A recuperação ocorre no início do ciclo seguinte via reajuste contratual.

- Imposto de Renda: $25 \%^{54}$, conferindo uma renda líquida mensal inicial de $\mathrm{R} \$ 8,475$ (ajustada conforme a inflação a cada ciclo de 1 ano, seguindo os reajustes dos aluguéis).

- Reserva para constituição do FRA: 4\% da receita bruta de locação.

\section{Comportamento da carteira:}

- Receita mensal inicial disponível para o investidor: $\mathrm{R} \$$ 8,023. Receita essa que não é reinvestida na carteira, e que fica estabilizada em Reais em cada ciclo anual, sofrendo, portanto a perda relativa à inflação.

- Valor patrimonial da carteira: estabilizado no patamar do IGP-M.

Para ilustrar o comportamento, os autores apresentam os gráficos da Figura 17 e da Figura 18, utilizando o comportamento do IGP-M no horizonte da análise.

\footnotetext{
${ }^{54}$ Adotado pelos autores, apesar do imposto ser calculado em patamares de renda que oscilam entre a isenção e à alíquota de $27,5 \%$.
} 


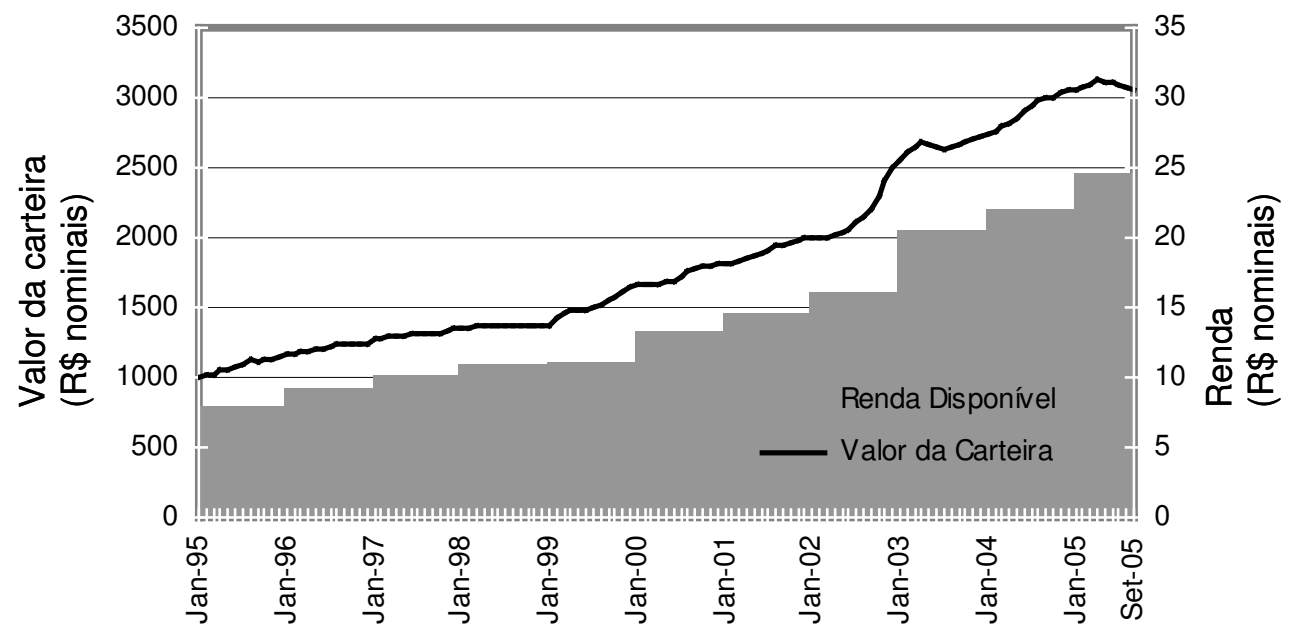

Figura 17 - Renda e Valor da Carteira Imobiliária em Reais nominais (fonte: Rocha Lima; Takaoka, 2006)

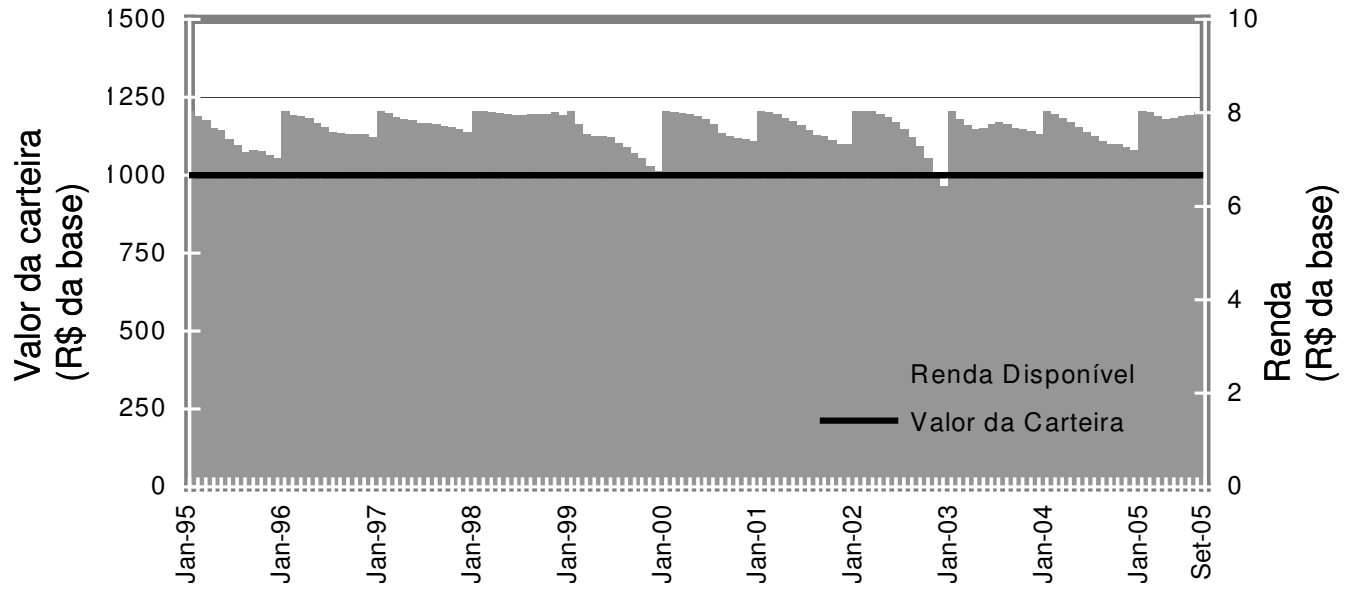

Figura 18 - Renda e Valor da Carteira Imobiliária em Reais da base - janeiro/95 (fonte: Rocha Lima; Takaoka , 2006)

\subsection{Caderneta de poupanca}

Simulando a aplicação dos recursos ( $\mathrm{R} \$ 1.000,00)$, em janeiro de 1995, na caderneta de poupança, e dela retirando mensalmente a quantia equivalente à renda líquida produzida no portfólioR, os autores concluem que, ao final do cicloR (setembro de 2005), a caderneta de poupança teria como saldo o valor equivalente a $34,8 \%$ do valor do portfólioR, ou seja, muito 
inferior ao do portfólioR, a despeito das altas taxas de juros praticadas no Brasil com foco no controle inflacionário.

Os autores ainda exploram a hipótese de extinção da caderneta de poupança, assumindo a manutenção da renda média do último ano desta carteira, e considerando a variação do IGP-M equivalente a taxa de $6 \%$ ao ano. Com estas considerações, a carteira se extinguiria após 34 meses a partir do final do cicloR.

\subsection{Investimentos financeiros com rendimento atrelado ao CDI}

Caso o investimento na data base da análise fosse feito em instrumentos financeiros que pagassem a taxa CDI mensal, o imposto de renda correspondente seria de 22,5\% nos dois primeiros anos e de $15 \%$ a partir do terceiro ano de aplicação (ROCHA LIMA; TAKAOKA, 2006). Ou seja, no longo prazo esta carteira apresenta a vantagem de uma tributação sobre a renda inferior à do portfólioR.

No entanto, ao final do cicloR, o valor da carteira financeira calculado pelos autores equivale a $98 \%$ do valor do portfólioR na mesma data, mostrando uma pequena diferença em prol deste.

Da mesma forma que para a caderneta de poupança, os autores simularam a extinção da carteira de investimentos financeiros, chegando ao prazo de 195 meses.

\section{4 Carteira de acões}

Caso o investimento na data base da análise fosse feito em ações que acompanhassem o Ibovespa $^{55}$, e considerando o imposto de renda de $15 \%$ para os períodos em que as ações são

\footnotetext{
55 Índice calculado pela BOVESPA (Bolsa de Valores de São Paulo) com a finalidade de servir como indicador médio do comportamento do mercado. É o valor atual, em moeda corrente, de uma carteira teórica de ações
} 
vendidas com lucro, a simulação de Rocha Lima e Takaoka (2006), apresenta que, ao final do cicloR a carteira de ações equivaleria a 73,9\% do valor do portfólioR.

Para a mesma simulação de extinção feita para as outras carteiras, os autores estimam que se o Ibovespa sofrer uma variação média de 16,8\% ao ano, a carteira de ações seria extinta em 120 meses.

Destas simulações os autores concluem que os empreendimentos de base imobiliária são opções de investimento competitivas quando o foco do investidor está no longo prazo e na obtenção de uma renda perene. Vale lembrar ainda que no período analisado as taxas de juros vigentes no Brasil eram elevadas, dando a idéia de que os investimentos em empreendimentos de base imobiliária não seriam escolhas tão rentáveis como as demais opções disponíveis no mercado.

\section{5 Fundo de investimento imobiliário (FII)}

Com o objetivo de reforçar a atratividade dos investimentos ancorados em empreendimentos de base imobiliária, os autores fazem a simulação para uma carteira formada de quotas de um FII. Para tal, estimam os custos de gestão e administração dos FIIs em torno de $10 \%$ da renda operacional gerada, e consideraram a isenção do imposto de renda dos resultados derivados de FII apregoada na atual legislação desde que:

- o FII tenha mais do que 50 investidores,

- o investidor seja pessoa física e tenha menos de $10 \%$ das quotas do FII.

constituída em 02/01/1968, a partir de uma aplicação hipotética, supondo não ter sido efetuado nenhum investimento adicional desde então, considerando-se somente os ajustes efetuados em decorrência da distribuição de proventos pelas empresas emissoras. Dessa forma, o índice reflete não apenas as variações dos preços das ações, mas também o impacto da distribuição dos proventos, sendo considerado um indicador que 
Desta forma, constata-se que o investimento em FII gera uma renda maior do que a do portfólioR, já que, ancorado no mesmo produto e sujeito aos mesmos riscos, apresenta uma vantagem tributária. Sendo assim, para comparar esta carteira com o portfólioR, os autores consideram que, da renda líquida gerada mensalmente, o investidor saca o equivalente ao valor líquido do aluguel do portfólioR e aplica o saldo na caderneta de poupança, investimento financeiro mais conservador.

Portanto, a renda mensal consumida pelo investidor é idêntica à alcançada na carteira imobiliária, e o valor da carteira de investimento sofre incrementos sucessivos conforme o saldo acumulado na caderneta de poupança, já que o volume de recursos estará investido em [i] FII que mantém um valor estável no patamar do IGP-M, em função da premissa de evolução do valor do imóvel feita na carteira de referência; e [ii] caderneta de poupança, correspondente à renda extra gerada e não consumida pelo investidor.

Os gráficos da Figura 19 e da Figura 20 demonstram os aspectos aqui levantados, deixando claro que, ao final do período em análise esta carteira terá um valor maior do que o do portfólioR.

avalia o retorno total de suas ações componentes. A carteira hipotética é reavaliada a cada quadrimestre de modo a ser representativa das negociações efetuadas na bolsa de valores. 


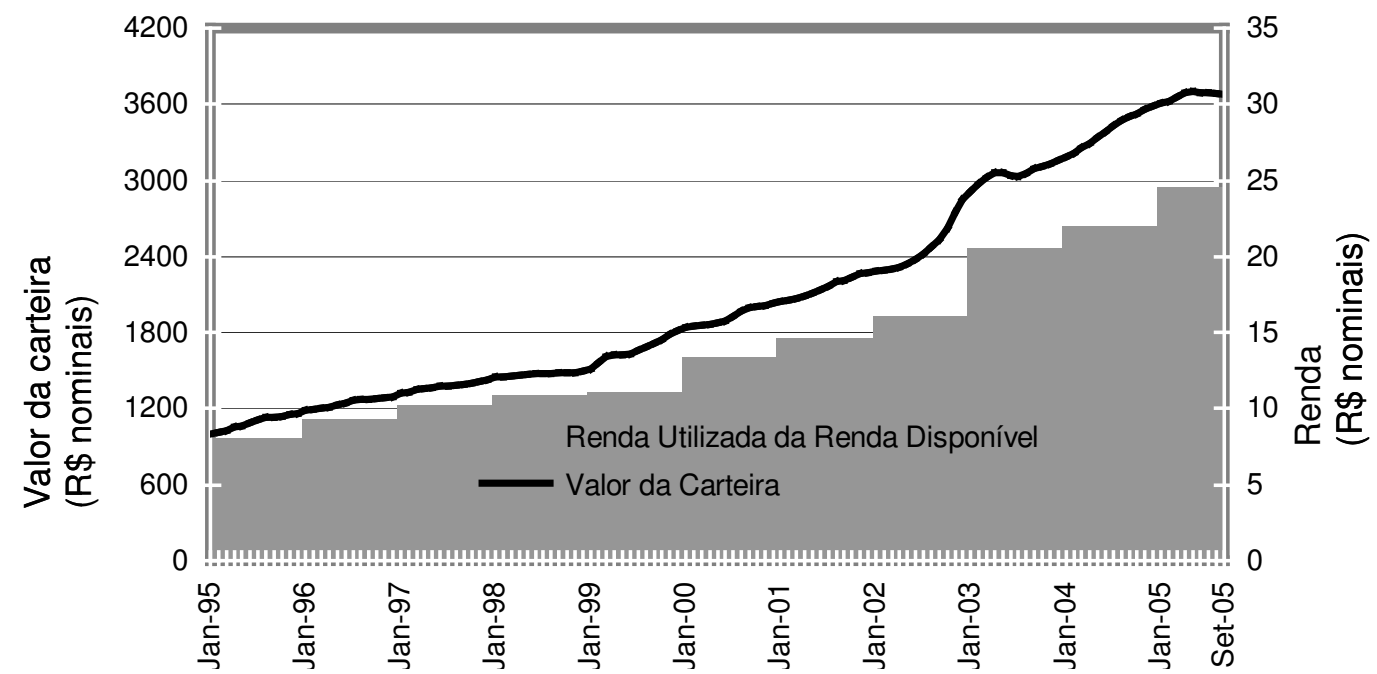

Figura 19 - Renda mensal e Valor da Carteira "FII + caderneta de poupança” em Reais nominais (fonte: Rocha Lima; Takaoka, 2006)

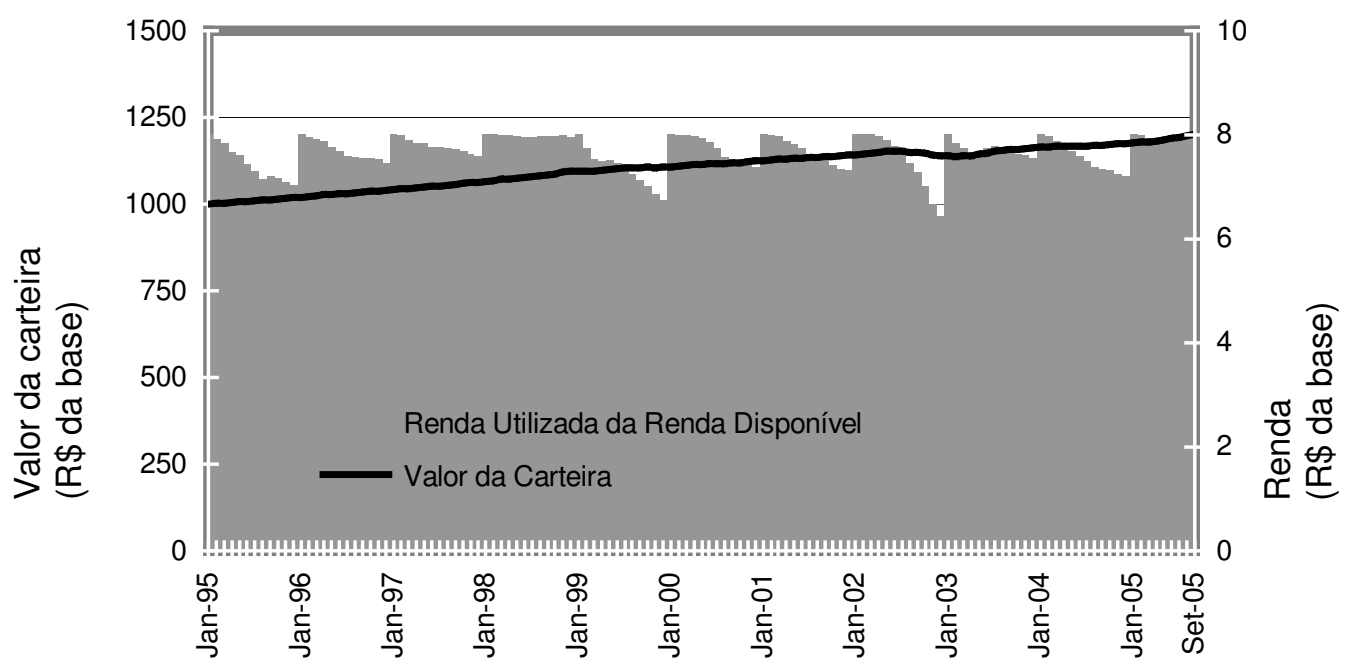

Figura 20 - Renda mensal e Valor da Carteira "FII + caderneta de poupança” em Reais da base - janeiro/95 (fonte: Rocha Lima; Takaoka, 2006)

Nota-se, portanto que o investimento em FII, um dos ambientes possíveis para a securitização, é ainda mais atraente aos investidores que têm foco no longo prazo, com a obtenção de uma renda perene. 
Fazendo a mesma análise para títulos emitidos no ambiente de uma SPE, ou seja, supondo a criação de uma SPE para a securitização de um EEL que tenha o mesmo desempenho projetado do portfólioR, poder-se-ia chegar a um valor da carteira no final do cicloR inferior à da carteira ancorada em quotas de um FII. Isto porque a SPE permite a criação de títulos protegidos por outros, ou seja, quanto maior for o grau de proteção, gerando menos exposição ao risco, menor será a rentabilidade esperada. Por outro lado, os títulos que oferecem proteção àqueles mais seguros, poderiam compor uma carteira que apresenta um valor superior ao da carteira ancorada em FII.

\section{6 Comentários e consideracões}

No mercado de EELs há quem afirme que os contratos de locação dos imóveis comerciais que foram leiloados pelos bancos não garantem uma rentabilidade aceitável para os investidores, alegando que os contratos privilegiam o locatário e que os imóveis, na sua grande maioria agências bancárias, teriam um espectro de mercado muito restrito, necessitando de um grande esforço de reciclagem caso os contratos firmados fossem rescindidos. Desta forma, buscando reforçar a validade dos dados apresentados por Rocha Lima e Takaoka (2006), faz-se a seguir uma comparação entre a rentabilidade atribuída à carteira de FII no estudo dos autores e a rentabilidade efetivamente obtida em um fundo imobiliário lastreado em EEL. Trata-se apenas de validar a rentabilidade arbitrada pelos autores e não de promover discussões acerca do mercado no qual o EEL se insere, ou de analisar a qualidade do investimento neste FII especificamente.

Em 2004, a Caixa Econômica Federal atuou como coordenadora líder da distribuição do Fundo de Investimento Imobiliário Torre Almirante, fundo imobiliário que tem como lastro o edifício de 36 andares de mesmo nome, localizado no centro do Rio de Janeiro e locado em setembro de 2004, a Petróleo Brasileiro S.A. - PETROBRAS pelo prazo de 60 meses, 
renováveis pelo mesmo período. Tomando-se os dados de rentabilidade deste FII (vide Tabela 3) tem-se uma rentabilidade nominal ${ }^{56}$ mensal média em 2005 de 1,02\%.

\begin{tabular}{c|c|c}
\hline Mês & $\mathbf{2 0 0 5}$ & $\mathbf{2 0 0 6}$ \\
\hline Janeiro & $1,02 \%$ & $1,00 \%$ \\
\hline Fevereiro & $1,02 \%$ & $1,00 \%$ \\
\hline Março & $1,02 \%$ & \\
\hline Abril & $1,02 \%$ & \\
\hline Maio & $1,02 \%$ & \\
\hline Junho & $1,02 \%$ & \\
\hline Julho & $1,02 \%$ & \\
\hline Agosto & $1,02 \%$ & \\
\hline Setembro & $1,01 \%$ & \\
\hline Outubro & $1,00 \%$ & \\
\hline Novembro & $1,00 \%$ & \\
\hline Dezembro & $0,99 \%$ & \\
\hline Acumulado no Ano & $\mathbf{1 2 , 1 9 \%}$ & $\mathbf{1 , 9 9 \%}$ \\
\hline Média Mensal & $\mathbf{1 , 0 2} \%$ & $\mathbf{1 , 0 0 \%}$ \\
\hline
\end{tabular}

Tabela 3 - Rentabilidade do FII Torre Almirante, já deduzidas as taxas de administração, performance e demais custos do fundo (fonte: Caixa Econômica Federal)

Pela análise feita por Rocha Lima e Takaoka (2006), da renda do aluguel correspondente a R\$ 11,30, tem-se as seguintes deduções: [i] FRA correspondente a R \$ 0,452 (4\% da renda bruta de locação), [ii] taxa de administração do fundo correspondente a $\mathrm{R} \$ 1,13$ (10\% da renda operacional gerada), resultando na receita líquida mensal de $\mathrm{R} \$ 9,718$, ou seja, uma rentabilidade nominal de $0,97 \%$.

Comparando este valor com a rentabilidade média do FII Torre Almirante, notamos que os autores trabalham com dados perfeitamente alinhados com a realidade, tornando a discussão acerca da rentabilidade dos investimentos em imóveis comerciais leiloados pelos bancos inócua para o presente trabalho.

\footnotetext{
${ }^{56}$ Utiliza-se nominal para frisar que os cálculos foram feitos em Reais nominais, não se considerando portanto a perda inflacionária.
} 
A Figura 21 e a Figura 22 abaixo, apresentam o resumo das simulações feitas anteriormente, mostrando que em setembro de 2005 a Carteira Imobiliária apresenta valor superior às demais alternativas financeiras, ficando atrás somente da carteira ancorada em FII.

Além disso, nota-se que em alguns momentos dentro do período em análise, carteiras financeiras como a de ações e a de CDI apresentam valores superiores à carteira imobiliária, enfatizando a diferença entre os riscos de cada aplicação.

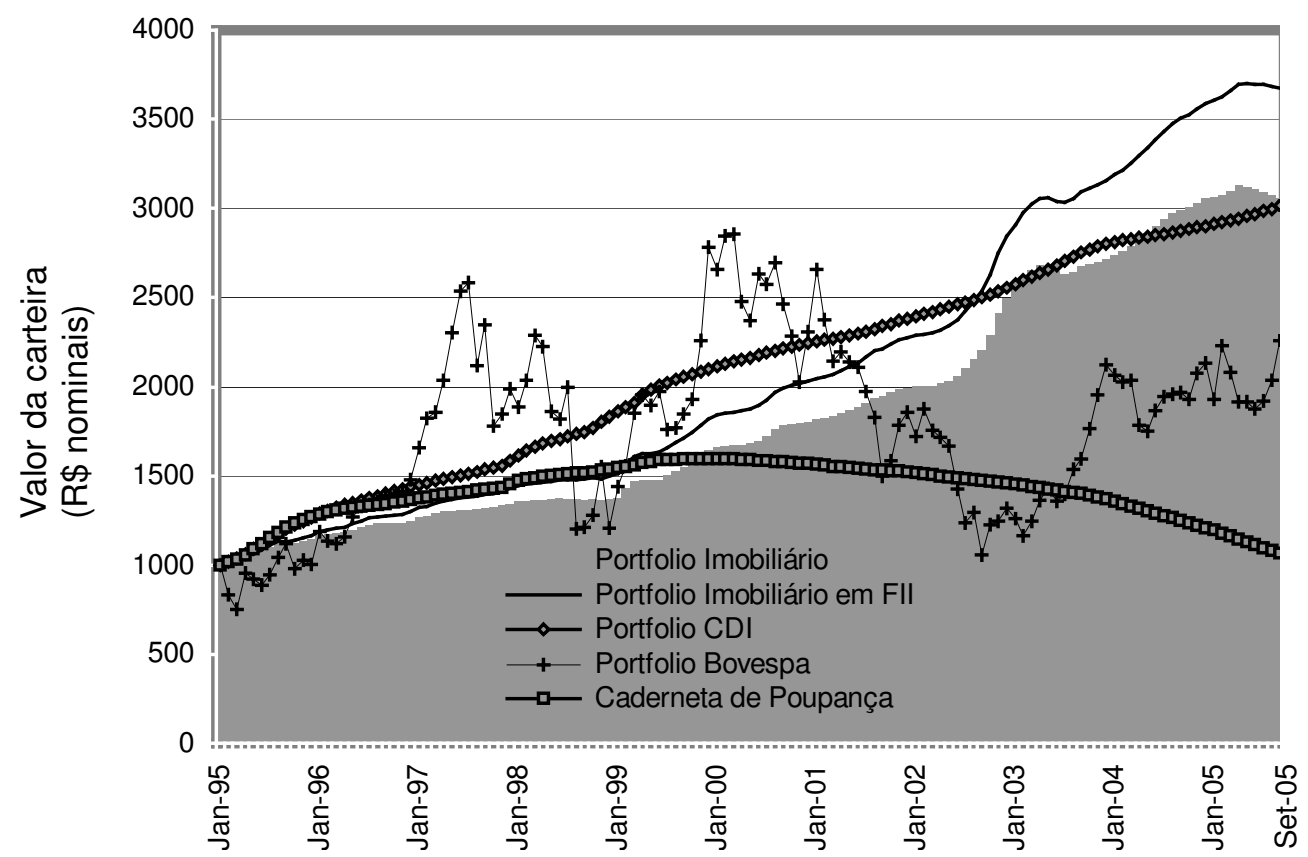

Figura 21 - Valor das carteiras em Reais nominais (fonte: Rocha Lima; Takaoka, 2006) 


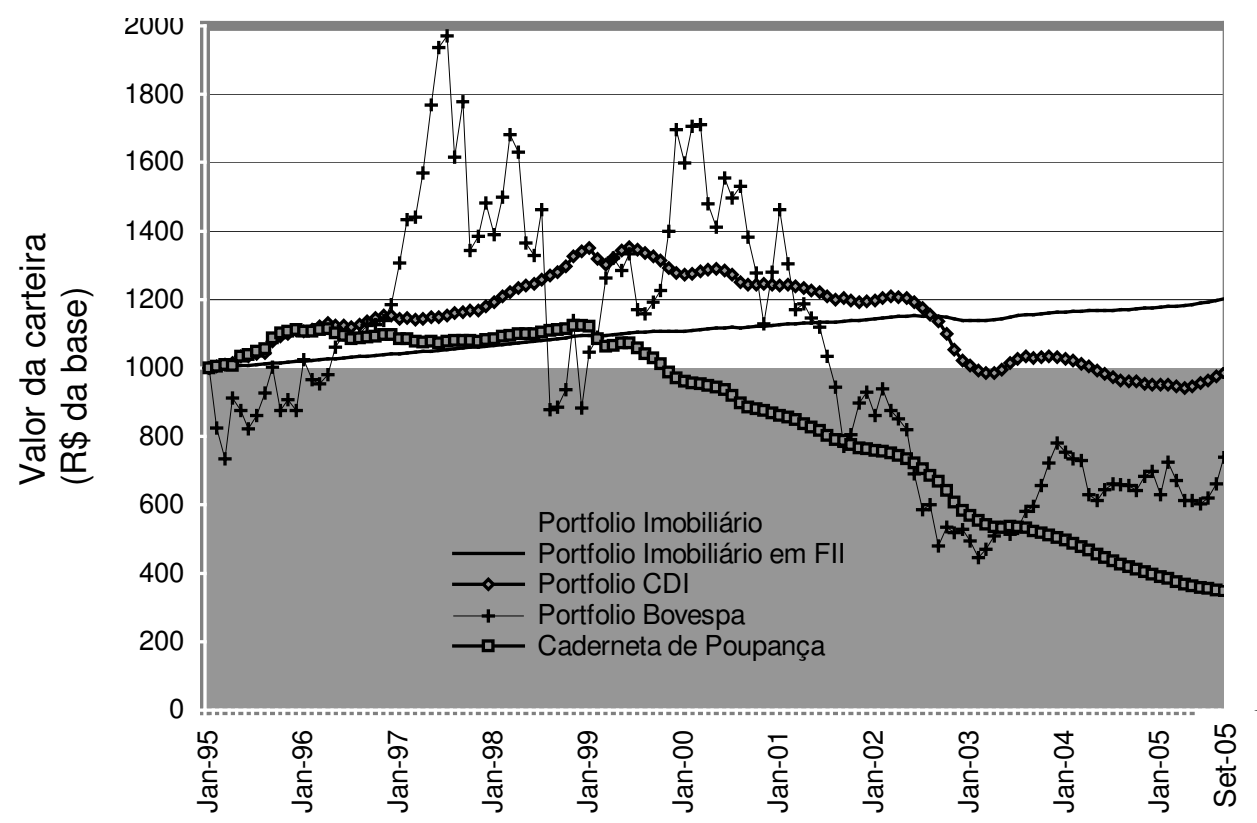

Figura 22 - Valor das carteiras em Reais da base - janeiro/95 (fonte: Rocha Lima; Takaoka, 2006)

Conforme ponderação dos próprios autores, esta análise, por mesclar as ocorrências no período em estudo com comportamento de rendas imobiliárias de um período mais recente, tem o objetivo de especular sobre a formação das carteiras de poupança para a obtenção de renda perene, utilizando os parâmetros de impostos da economia brasileira na conjuntura do final do ano de 2005. Desta forma, não se trata de verificar comportamentos alternativos de diferentes carteiras, nem de projetar cenários adiante.

À parte da análise de rentabilidade entre as opções de investimento, deve-se considerar a dificuldade de partilhar imóveis fisicamente, sem que se tenha perda de qualidade do investimento pela descentralização da gestão. Ou seja, a comparação feita por Rocha Lima e Takaoka (2006) é válida em termos de rentabilidade, mas deixa de lado a discussão a respeito da atratividade sobre os pequenos investidores que não possuem recursos suficientes para aplicar em um EEL. 
Para atrair estes investidores e proporcionar aos mesmos e aos demais um portfólio mais diversificado e, portanto mais protegido dos riscos envolvidos, é que se apresenta a securitização, aqui representada pelos FIIs, mostrando que é possível aos poupadores acessar investimentos lastreados em empreendimentos de base imobiliária mesmo sem que se tenha a disponibilidade do montante para a compra do mesmo. 


\section{ESTUdo SOBRE O DIRECIONAMENTO DA POUPANÇA BRASILEIRA PARA A SECURITIZAÇÃo DE EELS}

Considerando [i] a carência de fontes de recursos disponíveis para o desenvolvimento de empreendimentos imobiliários, [ii] a atratividade do investimento lastreado em EELs para investidores com foco na geração de uma renda mensal e perene, [iii] a flexibilidade propiciada pela securitização no que diz respeito à partição do investimento e às garantias oferecidas aos investidores e [iv] o histórico do mercado americano de EELs securitizados; faz-se a seguir uma projeção do mercado brasileiro de securitização de EELs, tomando como referência o mercado de REITs americanos.

Para tanto, seguir-se-á a mesma lógica adotada por Rocha Lima $^{36}$ em seu estudo sobre o redirecionamento da poupança brasileira para o mercado securitizado de empreendimentos de base imobiliária, restringindo, entretanto, o enfoque ao mercado securitizado de EELs. Além disso, o presente estudo utiliza em suas simulações as projeções de evolução do PIB já apresentadas anteriormente no item 5. 8.

Este estudo tem o intuito de mostrar ao leitor o potencial de alavancagem do mercado de edifícios de escritórios da cidade de São Paulo diante da migração de recursos da poupança brasileira para ambientes da securitização.

\section{1 Capitalizacão de EELs securitizados no mercado brasileiro}

Como já exposto anteriormente, o mercado de EELs é intimamente ligado ao desempenho da economia, o que corrobora o estabelecimento de uma correlação entre o PIB e os recursos aplicados nestes empreendimentos. A Tabela 4 apresenta os valores do PIB americano e uma estimativa da capitalização dos REITs específicos de EEL. Houve a necessidade de se estimar estes valores pela falta de dados específicos deste mercado, sendo assim, adotou-se como 
premissa que a distribuição dos REITs nos últimos 10 anos manteve-se constante, sendo que o mercado de EEL tem uma representatividade de $16,8 \%^{57}$ nos REITs.

\begin{tabular}{r|r|r|r}
\hline \multicolumn{1}{c|}{ Ano } & $\begin{array}{c}\text { PIB americano } \\
\text { (US\$ bilhões - moeda } \\
\text { corrente) }\end{array}$ & $\begin{array}{c}\text { Capitalização dos } \\
\text { REIT de EEL* } \\
\text { (US\$ bilhões - } \\
\text { moeda corrente) }\end{array}$ & $\begin{array}{c}\text { REIT EEL } \\
\text { PIB }\end{array}$ \\
\hline 1994 & $7.072,2$ & 7,4 & $0,11 \%$ \\
\hline 1995 & $7.397,7$ & 9,7 & $0,13 \%$ \\
\hline 1996 & $7.816,9$ & 14,9 & $0,19 \%$ \\
\hline 1997 & $8.304,3$ & 23,6 & $0,28 \%$ \\
\hline 1998 & $8.747,0$ & 23,2 & $0,27 \%$ \\
\hline 1999 & $9.268,4$ & 20,9 & $0,23 \%$ \\
\hline 2000 & $9.817,0$ & 23,3 & $0,24 \%$ \\
\hline 2001 & $10.128,0$ & 26,0 & $0,26 \%$ \\
\hline 2002 & $10.469,6$ & 27,2 & $0,26 \%$ \\
\hline 2003 & $10.971,2$ & 37,7 & $0,34 \%$ \\
\hline 2004 & $11.734,3$ & 51,7 & $0,44 \%$ \\
\hline "Fonte: Bureau of Economic Analysis - U.S. Department of Commerce \\
**Fonte: NAREIT (National Association of Real Estate Investment Trusts)
\end{tabular}

Tabela 4 - O PIB americano e a capitalização dos REITs

Com os dados acima, chega-se ao gráfico exibido na Figura 23, criando-se uma linha de tendência para a relação entre a poupança em REITs de EELs e o PIB americano, relação esta que em 2004 era de $0,44 \%$.

Ciente de que a cultura americana de investimento diverge da brasileira no que diz respeito ao entendimento de risco ${ }^{58}$, na ausência de parâmetros mais próximos à realidade brasileira que está porvir e na tentativa de traçar uma meta de desenvolvimento para o mercado nacional de securitização, utiliza-se o mercado americano de EELs securitizados como benchmark. Sendo assim, arbitra-se que o mercado brasileiro de EELs securitizados terá daqui a 10 anos uma

\footnotetext{
${ }^{57}$ Esta é a média da participação de EELs nos REITs americanos na última década (fonte: NAREIT).
} 
configuração similar a que apresenta hoje o mercado americano. Para tanto, faz-se uso da relação entre REIT de EELs e PIB da última década do mercado americano como base da projeção desta relação para a próxima década do mercado brasileiro. Assim, analisando a linha de tendência, arbitra-se a relação de $0,32 \%$ como meta de longo prazo (10 anos) para se analisar o mercado brasileiro.

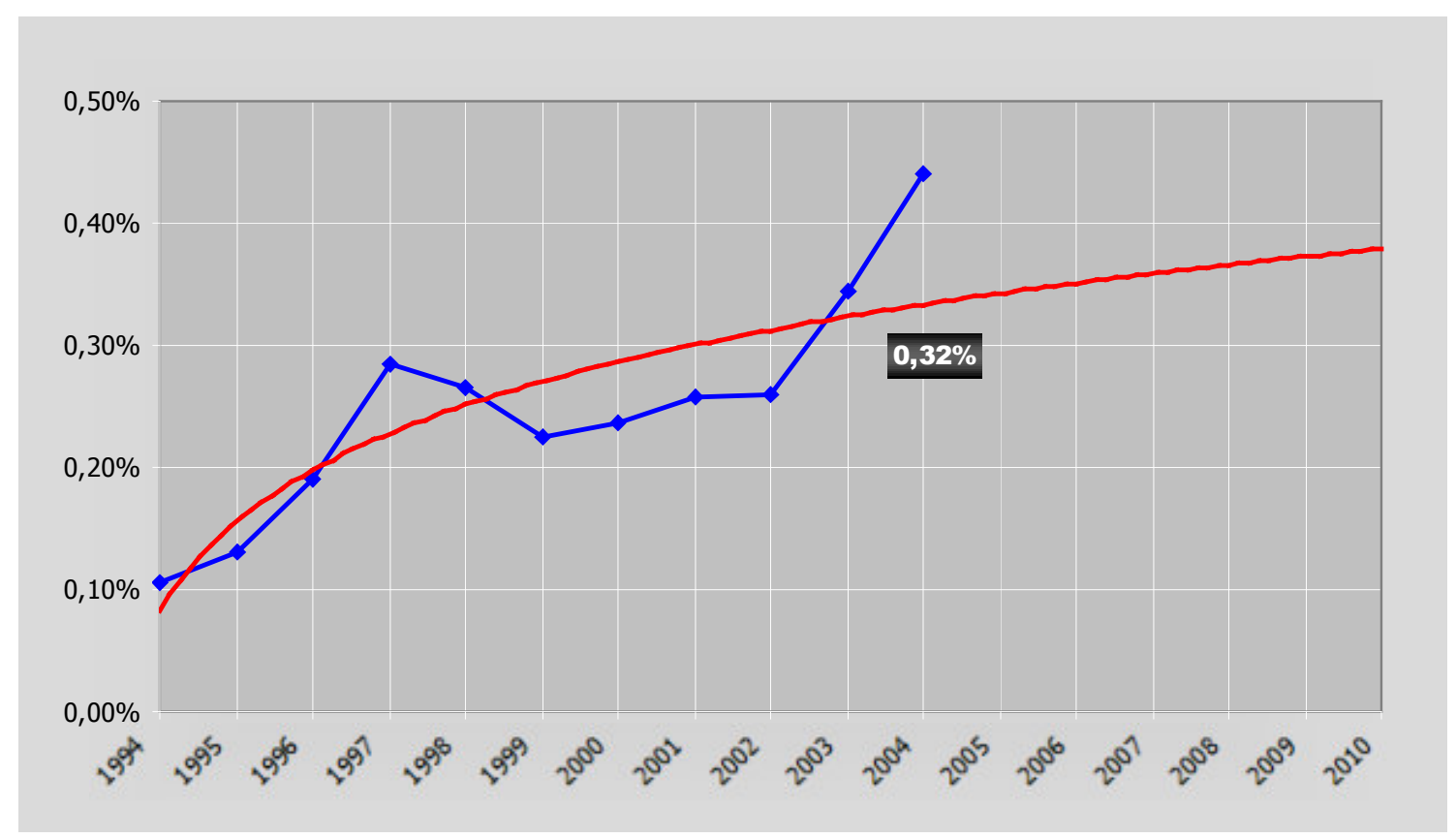

Figura 23 - Poupança em REITs (EEL) frente ao PIB americano

De outro lado, seguindo a mesma arbitragem feita anteriormente para a evolução do PIB brasileiro, arbitra-se a este indicador os seguintes parâmetros:

58 A primeira é voltada ao mercado de capitais, tendo investidores conscientes de que suas aplicações estão sujeitas aos riscos dos mercados no qual investem; enquanto que a segunda apresenta investidores com perfil mais conservador, habituados à intermediação bancária para alavancar os empreendimentos 
- $4,5 \%$ ao ano em média, baseado nas metas estabelecidas no Plano Plurianual (PPA) do Governo Federal;

- $2 \%$ ao ano, sendo este o patamar médio de evolução do PIB no período de 1995 a $2002 .^{59}$

Outro dado de partida para o estudo é o volume de recursos aplicados em EELs securitizados até $2004^{60}$ no mercado brasileiro. Para estimar este montante, fez-se um levantamento dos fundos imobiliários (cadastrados na Comissão de Valores Mobiliários - CVM) que têm EELs em carteira, chegando-se a 900 milhões de Reais. Como a grande maioria das securitizações brasileiras de EELs foi feita via FII, considera-se o levantamento citado representativo do mercado securitizado de EELs.

Diante destes dados, estabelece-se duas projeções para a participação dos investimentos em EELs securitizados no PIB: uma de crescimento mais acelerado (embasada em uma curva logarítmica), e outra de crescimento amortecido (embasada em uma curva exponencial), fazendo com que ambas atinjam a meta de participação de $0,32 \%$ no PIB ao final de 10 anos. Destas duas curvas é extraída uma curva conservadora baseada no incremento mínimo anual das duas anteriores (curva de crescimento conservador). Os dados são apresentados na Tabela 5 e na Tabela 6.

\footnotetext{
${ }^{59}$ No estudo apresentado por Rocha Lima, o autor utiliza como parâmetro de evolução do PIB a média de $3 \%$ ao ano, mas, para dar consistência à discussão aqui apresentada, optou-se por revisar a premissa adotada equiparando-a àquela utilizada no estudo da recuperação da atratividade do investimento no mercado paulistano de EELs.

${ }^{60} \mathrm{O}$ estudo é apresentado com base em dados de 2004 devido à indisponibilidade de dados mais recentes sobre o PIB até a data de publicação deste trabalho,
} 


\begin{tabular}{|c|c|c|c|c|c|c|c|c|}
\hline & \multirow{3}{*}{ Ano } & \multirow{3}{*}{$\begin{array}{c}\text { PIB } \\
\text { R\$ } \\
\text { bilhões } \\
\text { de } 2004\end{array}$} & \multicolumn{2}{|c|}{$\begin{array}{c}\text { Meta de participaçäo dos } \\
\text { investimentos em Real } \\
\text { Estate no PIB }\end{array}$} & \multicolumn{3}{|c|}{$\begin{array}{c}\text { Recursos de investimento em Real Estate } \\
\text { novos esperado } \\
\text { R\$ bilhões de } 2004\end{array}$} & \multirow{2}{*}{\begin{tabular}{|c|c|c}
$\begin{array}{c}\text { Recursos } \\
\text { novos/ PIB }\end{array}$ \\
$\begin{array}{c}\text { posição } \\
\text { acumulada }\end{array}$
\end{tabular}} \\
\hline & & & \multicolumn{2}{|c|}{ crescimento } & \multicolumn{3}{|c|}{ crescimento agregado } & \\
\hline & & & acelerado & amortecido & acelerado & amortecido & conservador & $\begin{array}{c}\text { conservador } \\
\text { /PIB }\end{array}$ \\
\hline Referência & 2004 & $1.766,6$ & $0,05 \%$ & $0,05 \%$ & 0,90 & 0,90 & 0,90 & $0,05 \%$ \\
\hline \multirow{10}{*}{ Projeção } & 2005 & $1.846,1$ & $0,17 \%$ & $0,06 \%$ & 2,28 & 0,23 & 0,23 & $0,06 \%$ \\
\hline & 2006 & $1.929,1$ & $0,23 \%$ & $0,07 \%$ & 1,33 & 0,29 & 0,29 & $0,07 \%$ \\
\hline & 2007 & $2.015,9$ & $0,27 \%$ & $0,09 \%$ & 0,94 & 0,36 & 0,36 & $0,09 \%$ \\
\hline & 2008 & $2.106,6$ & $0,29 \%$ & $0,11 \%$ & 0,73 & 0,46 & 0,46 & $0,11 \%$ \\
\hline & 2009 & $2.201,3$ & $0,31 \%$ & $0,13 \%$ & 0,60 & 0,57 & 0,57 & $0,13 \%$ \\
\hline & 2010 & $2.300,3$ & $0,32 \%$ & $0,15 \%$ & 0,51 & 0,72 & 0,51 & $0,14 \%$ \\
\hline & 2011 & $2.403,8$ & $0,32 \%$ & $0,18 \%$ & 0,44 & 0,90 & 0,44 & $0,16 \%$ \\
\hline & 2012 & $2.511,9$ & $0,32 \%$ & $0,22 \%$ & 0,39 & 1,13 & 0,39 & $0,16 \%$ \\
\hline & 2013 & $2.624,9$ & $0,32 \%$ & $0,27 \%$ & 0,35 & 1,42 & 0,35 & $0,17 \%$ \\
\hline & 2014 & $2.743,0$ & $0,32 \%$ & $0,32 \%$ & 0,31 & 1,79 & 0,31 & $0,17 \%$ \\
\hline \multicolumn{5}{|l|}{ Acumulado } & 8,77 & 8,77 & 4,80 & \\
\hline
\end{tabular}

Tabela 5 - Projeções da participação da poupança na securitização de EELs frente ao PIB brasileiro (simulação para evolução anual do PIB de 4,5\%)

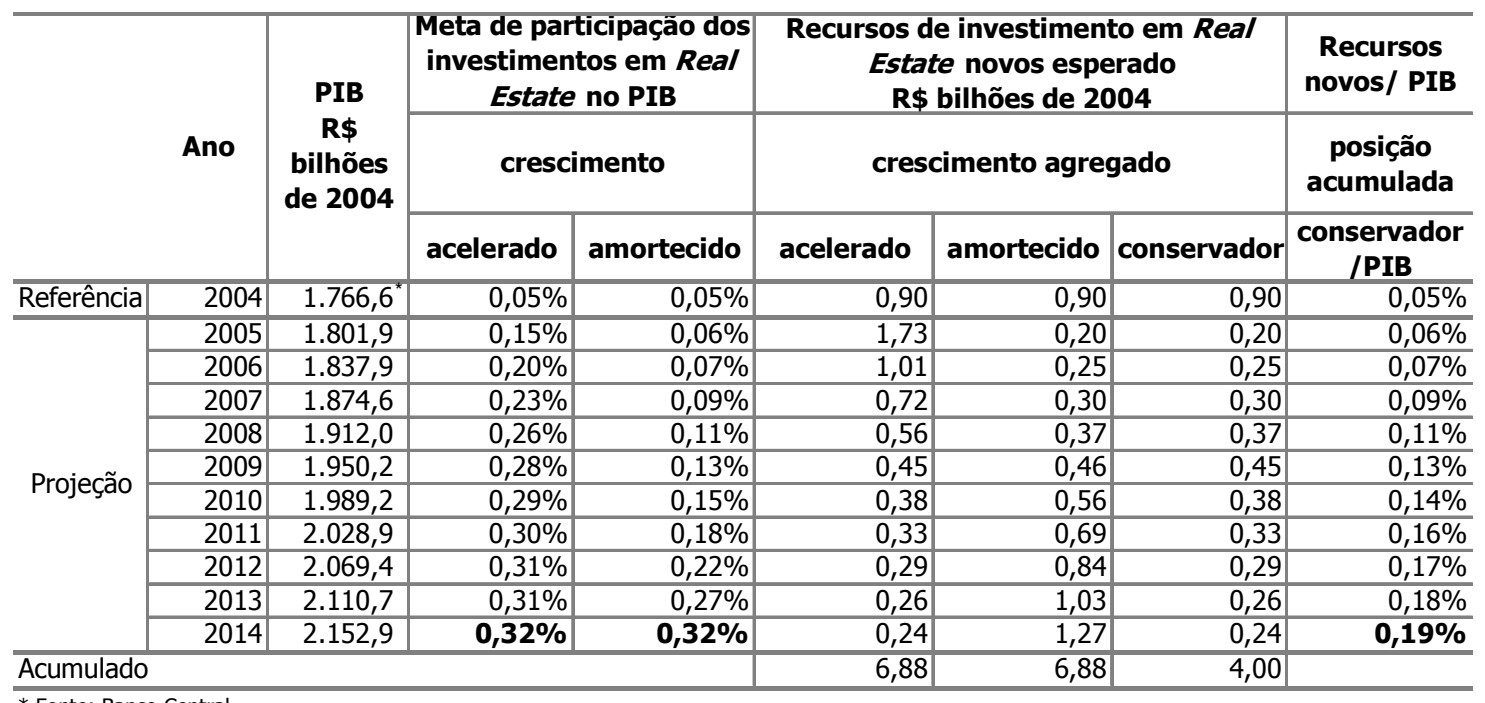

* Fonte: Banco Central

Tabela 6 - Projeções da participação da poupança na securitização de EELs frente ao PIB brasileiro (simulação para evolução anual do PIB de 2,0\%)

Tomando por base os dados acima apresentados, a Figura 24 e a Figura 25 apresentam as curvas acumuladas da projeção de poupança na securitização de EELs e o montante de recursos a ser atingido ao final de 10 anos, baseando-se na curva conservadora: $\mathrm{R} \$ 4,80$ 
bilhões, para o PIB evoluindo em média 4,5\% ao ano; e $\mathrm{R} \$ 4,00$ bilhões, para o PIB evoluindo em média $2,0 \%$ ao ano

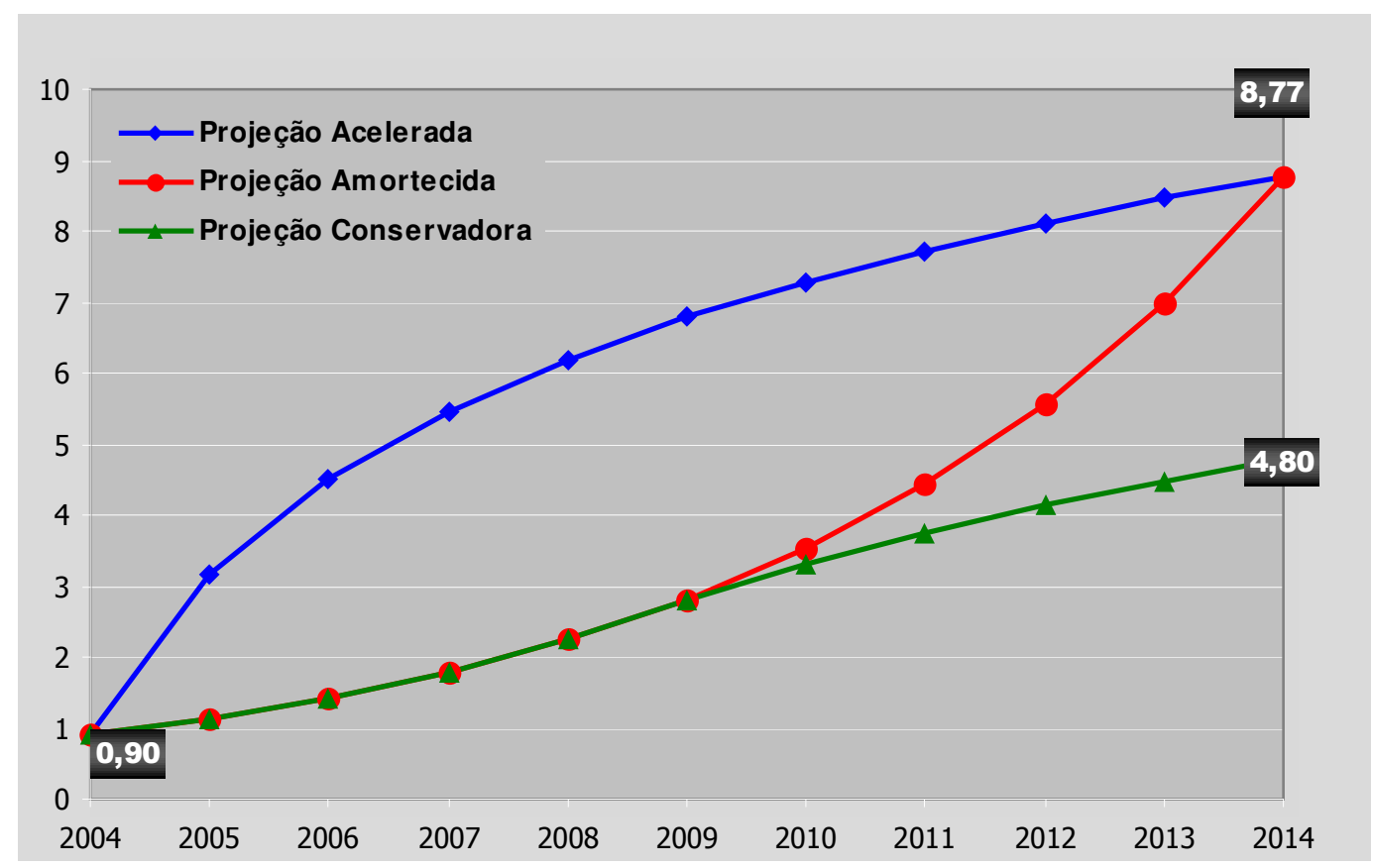

Figura 24 - Projeções de recursos novos na securitização de EELs: meta acumulada. Valores em R \$ bilhões de dezembro de 2004 (simulação para evolução anual do PIB de 4,5\%)

Observando os valores acumulados de participação da securitização de EELs no PIB, tem-se que a relação entre a capitalização da securitização de EELs e o PIB brasileiro, baseada na curva conservadora, para o ano de 2014 varia entre o,17\% e 0,19\%, em função da agressividade do desenvolvimento econômico. Ou seja, admite-se valores inferiores à meta de 0,32\% estipulada inicialmente (vide Figura 26 e Figura 27), em coerência com a diferença de maturidade entre o mercado americano e brasileiro evidenciada nos atuais volumes de capitalização. 


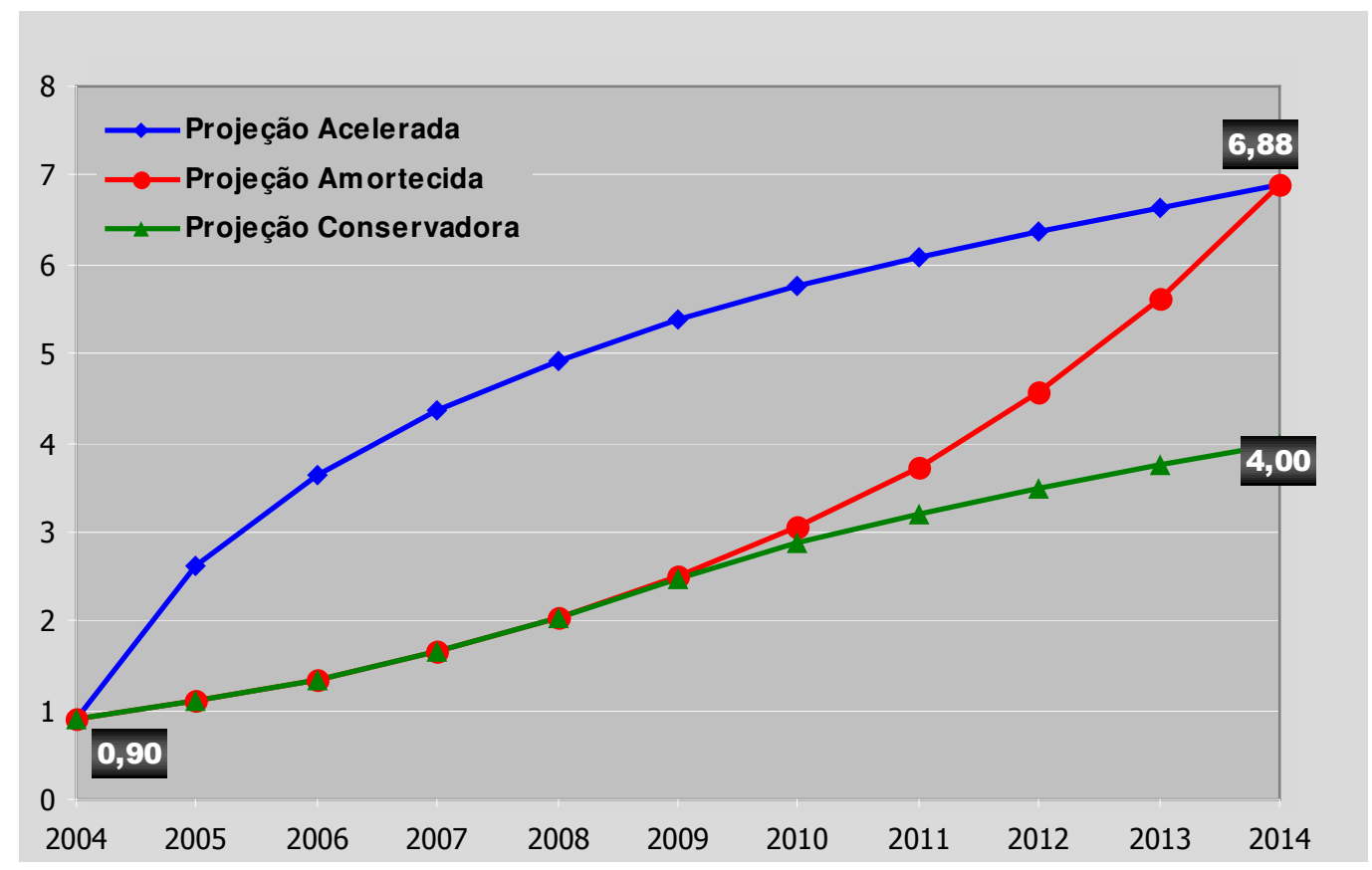

Figura 25 - Projeções de recursos novos na securitização de EELs: meta acumulada. Valores em R \$ bilhões de dezembro de 2004 (simulação para evolução anual do PIB de 2,0\%)

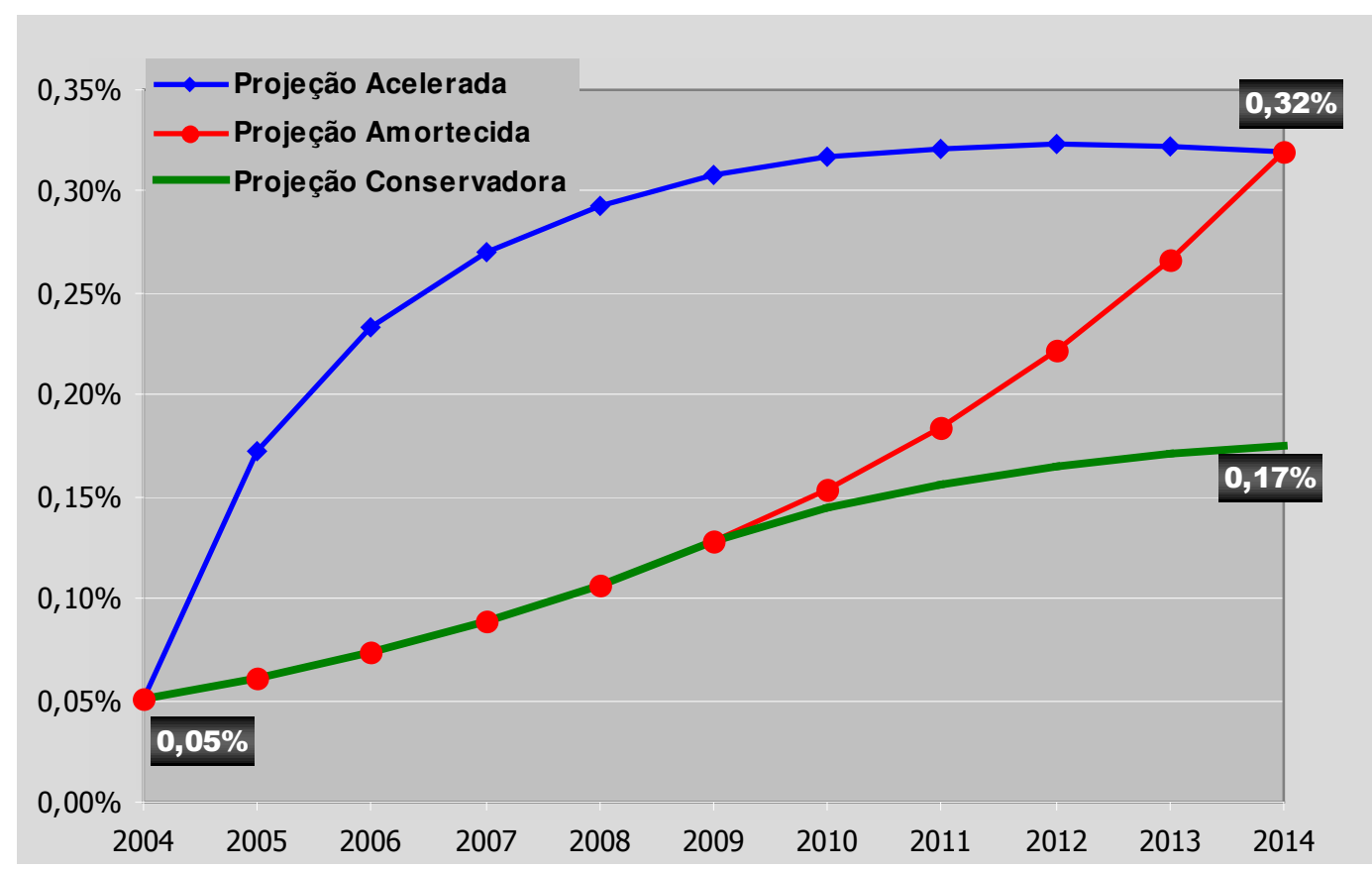

Figura 26 - Projeções buscando a meta de $0,32 \%$ em 10 anos da securitização de EELs frente ao PIB e a projeção conservadora (simulação para evolução anual do PIB de 4,5\%) 


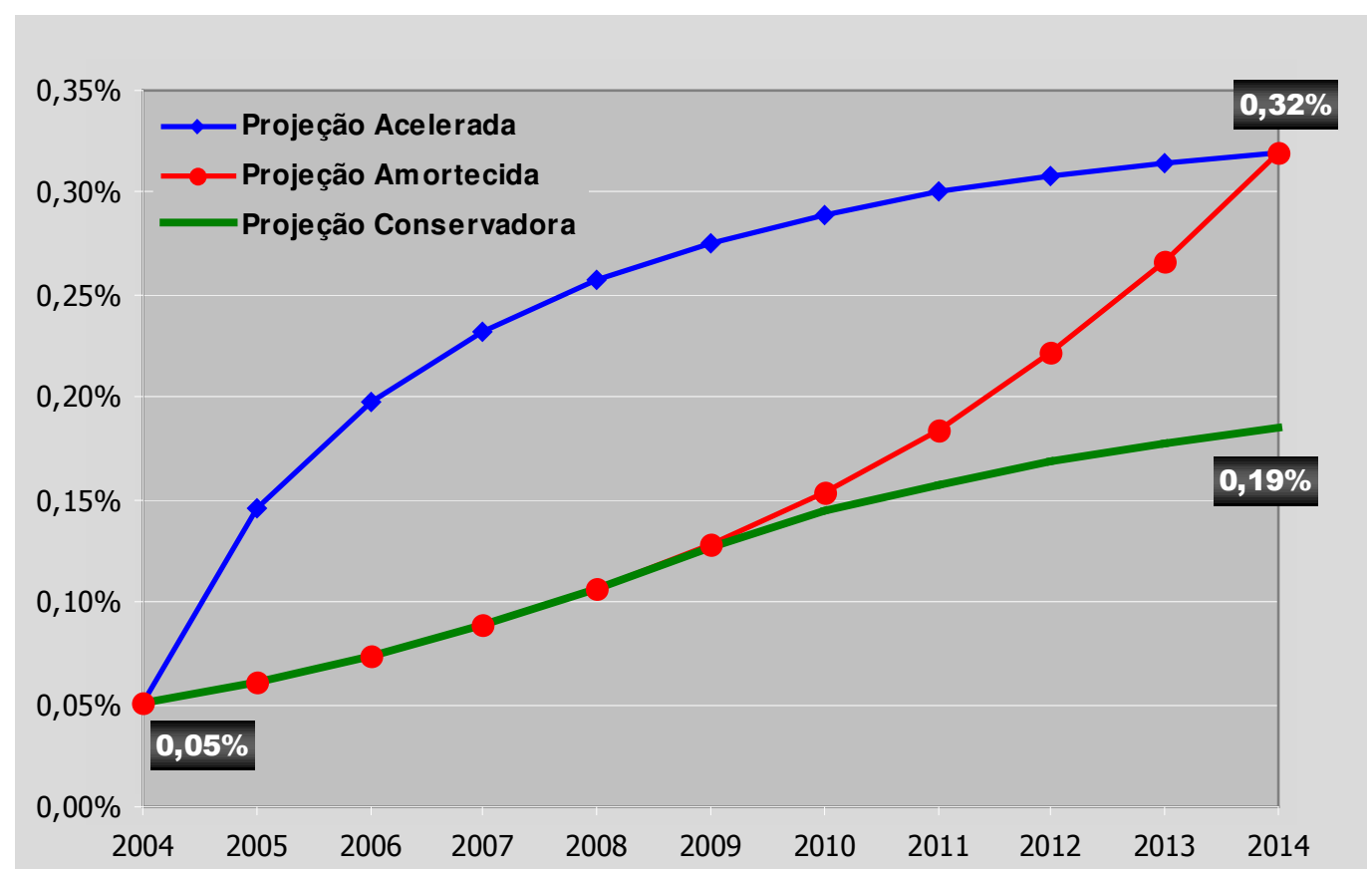

Figura 27 - Projeções buscando a meta de 0,32\% em 10 anos da securitização de EELs frente ao PIB e a projeção conservadora (simulação para evolução anual do PIB de 2,0\%)

Desta forma, é possível que em 2014 a capitalização brasileira em ambientes de securitização atinja valores entre 4,00 e 4,80 bilhões de Reais de dezembro de 2004. É importante frisar, no entanto que o comportamento do mercado e a postura mais ou menos agressiva dos agentes que nele operam influirá decisivamente no alcance destas metas. Neste sentido, o tratamento e a divulgação de informações livres de interesses mercadológicos pode proteger o mercado de ações especulativas, fazendo com que os ciclos recessivos em virtude do desequilíbrio entre oferta e demanda sejam cada vez mais curtos e apresentem perdas de rentabilidade cada vez menores. Pode-se afirmar assim que a constituição de um mercado secundário sólido auxiliaria neste processo, intensificando as trocas comerciais e possibilitando maior familiaridade e melhor acuidade na análise de valor dos papéis de securitização, protegendo assim os investidores. 


\section{2 Volume de poupanca conservadora a ser re-direcionado para títulos de securitização de EELs}

Comparando-se os resultados obtidos no item anterior com a poupança financeira ${ }^{61}$ projetada para a próxima década, tem-se o volume de re-direcionamento da poupança necessário para que o mercado brasileiro de securitização de EELs atinja a capitalização projetada.

Para tanto, admite-se que os recursos de poupança mantenham ao longo dos anos a mesma relação com o PIB, ou seja, os recursos poupados têm a mesma evolução arbitrada para o PIB.

A Tabela 7 e a Tabela 8 apresentam os resultados desta simulação. Na Figura 28 e na Figura 29 mostra-se a relação entre os recursos direcionados à securitização de EELs e o PIB, e a relação entre aqueles e os recursos poupados.

\begin{tabular}{|c|c|c|c|c|c|c|c|c|}
\hline & \multirow{3}{*}{ Ano } & \multirow{3}{*}{$\begin{array}{c}\text { PIB } \\
\text { R\$ } \\
\text { bilhões } \\
\text { de } 2004\end{array}$} & \multicolumn{2}{|c|}{$\begin{array}{c}\text { Poupança Financeira } \\
\text { depósitos de poupança } \\
\text { + depósitos a prazo }\end{array}$} & \multicolumn{4}{|c|}{$\begin{array}{c}\text { Recursos de investimento em Real Estate novos } \\
\text { esperados re-direcionados } \\
\text { R\$ bilhões de } 2004\end{array}$} \\
\hline & & & total & novos & Novos & Ren/ PIB & Ren/ PFt & $\begin{array}{l}\text { Ren } \\
\text { acumulado/ } \\
\text { PFt }\end{array}$ \\
\hline & & & PFt & PFn & Ren & & & \\
\hline Referência & 2004 & $1.766,6$ & $342,92^{*}$ & $37,51^{*}$ & & & & \\
\hline \multirow{10}{*}{ Projeção } & 2005 & $1.846,1$ & 358,35 & 15,43 & 0,23 & $0,01 \%$ & $0,06 \%$ & $0,06 \%$ \\
\hline & 2006 & $1.929,1$ & 374,48 & 16,13 & 0,29 & $0,01 \%$ & $0,08 \%$ & $0,14 \%$ \\
\hline & 2007 & $2.015,9$ & 391,33 & 16,85 & 0,36 & $0,02 \%$ & $0,09 \%$ & $0,23 \%$ \\
\hline & 2008 & $2.106,6$ & 408,94 & 17,61 & 0,46 & $0,02 \%$ & $0,11 \%$ & $0,33 \%$ \\
\hline & 2009 & $2.201,3$ & 427,34 & 18,40 & 0,57 & $0,03 \%$ & $0,13 \%$ & $0,45 \%$ \\
\hline & 2010 & $2.300,3$ & 446,57 & 19,23 & 0,51 & $0,02 \%$ & $0,11 \%$ & $0,54 \%$ \\
\hline & 2011 & $2.403,8$ & 466,67 & 20,10 & 0,44 & $0,02 \%$ & $0,09 \%$ & $0,61 \%$ \\
\hline & 2012 & $2.511,9$ & 487,67 & 21,00 & 0,39 & $0,02 \%$ & $0,08 \%$ & $0,66 \%$ \\
\hline & 2013 & $2.624,9$ & 509,62 & 21,95 & 0,35 & $0,01 \%$ & $0,07 \%$ & $0,70 \%$ \\
\hline & 2014 & $2.743,0$ & 532,55 & 22,93 & 0,31 & $0,01 \%$ & $0,06 \%$ & $0,73 \%$ \\
\hline
\end{tabular}

Tabela 7 - Recursos de poupança disponíveis para securitização de EELs: expressão do re-direcionamento (simulação para evolução anual do PIB de 4,5\%)

${ }^{61}$ Entenda-se como poupança a parte não consumida da renda e custodiada por intituições financeiras (depósitos de poupança e depósitos a prazo). 


\begin{tabular}{|c|c|c|c|c|c|c|c|c|}
\hline & \multirow{3}{*}{ Ano } & \multirow{3}{*}{$\begin{array}{c}\text { PIB } \\
\text { R\$ } \\
\text { bilhões } \\
\text { de } 2004\end{array}$} & \multicolumn{2}{|c|}{$\begin{array}{l}\text { Poupança Financeira } \\
\text { depósitos de poupança } \\
\text { + depósitos a prazo }\end{array}$} & \multicolumn{4}{|c|}{$\begin{array}{c}\text { Recursos de investimento em Real Estate novos } \\
\text { esperados re-direcionados } \\
\text { R\$ bilhões de } 2004\end{array}$} \\
\hline & & & total & novos & Novos & Ren/ PIB & Ren/ PFt & $\begin{array}{l}\text { Ren } \\
\text { acumulado/ } \\
\text { PFt }\end{array}$ \\
\hline & & & PFt & PFn & Ren & & & \\
\hline Referência & 2004 & $1.766,6$ & $342,92^{*}$ & $37,51^{*}$ & & & & \\
\hline \multirow{10}{*}{ Projeção } & 2005 & $1.801,9$ & 349,78 & 6,86 & 0,20 & $0,01 \%$ & $0,06 \%$ & $0,06 \%$ \\
\hline & 2006 & $1.837,9$ & 356,78 & 7,00 & 0,25 & $0,01 \%$ & $0,07 \%$ & $0,13 \%$ \\
\hline & 2007 & $1.874,6$ & 363,92 & 7,14 & 0,30 & $0,02 \%$ & $0,08 \%$ & $0,21 \%$ \\
\hline & 2008 & $1.912,0$ & 371,20 & 7,28 & 0,37 & $0,02 \%$ & $0,10 \%$ & $0,30 \%$ \\
\hline & 2009 & $1.950,2$ & 378,62 & 7,42 & 0,45 & $0,02 \%$ & $0,12 \%$ & $0,42 \%$ \\
\hline & 2010 & $1.989,2$ & 386,19 & 7,57 & 0,38 & $0,02 \%$ & $0,10 \%$ & $0,51 \%$ \\
\hline & 2011 & $2.028,9$ & 393,91 & 7,72 & 0,33 & $0,02 \%$ & $0,08 \%$ & $0,58 \%$ \\
\hline & 2012 & $2.069,4$ & 401,79 & 7,88 & 0,29 & $0,01 \%$ & $0,07 \%$ & $0,65 \%$ \\
\hline & 2013 & $2.110,7$ & 409,83 & 8,04 & 0,26 & $0,01 \%$ & $0,06 \%$ & $0,70 \%$ \\
\hline & 2014 & $2.152,9$ & 418,03 & 8,20 & 0,24 & $0,01 \%$ & $0,06 \%$ & $0,74 \%$ \\
\hline
\end{tabular}

Tabela 8 - Recursos de poupança disponíveis para securitização de EELs: expressão do re-direcionamento (simulação para evolução anual do PIB de 2,0\%)

Nota-se que a relação entre os recursos investidos em EELs na próxima década e a poupança acumulada no mesmo período é baixa, variando entre $0,73 \%$ e $0,74 \%$. Desta forma, pode-se concluir que o aquecimento do mercado de securitização brasileiro, para que o mesmo obtenha a longo prazo a mesma expressão atingida no mercado americano é viável através do re-direcionamento de parte dos recursos da poupança que atualmente estão abrigados nas altas taxas de juros do curto prazo.

Esta migração será possível com: [i] a redução da taxas de juros praticadas atualmente, sendo esta a direção para a qual a economia brasileira aponta, e [ii] o desenvolvimento do mercado secundário, possibilitando, assim, o aumento o número de transações e a aferição de valor dos títulos de EELs securitizados. 


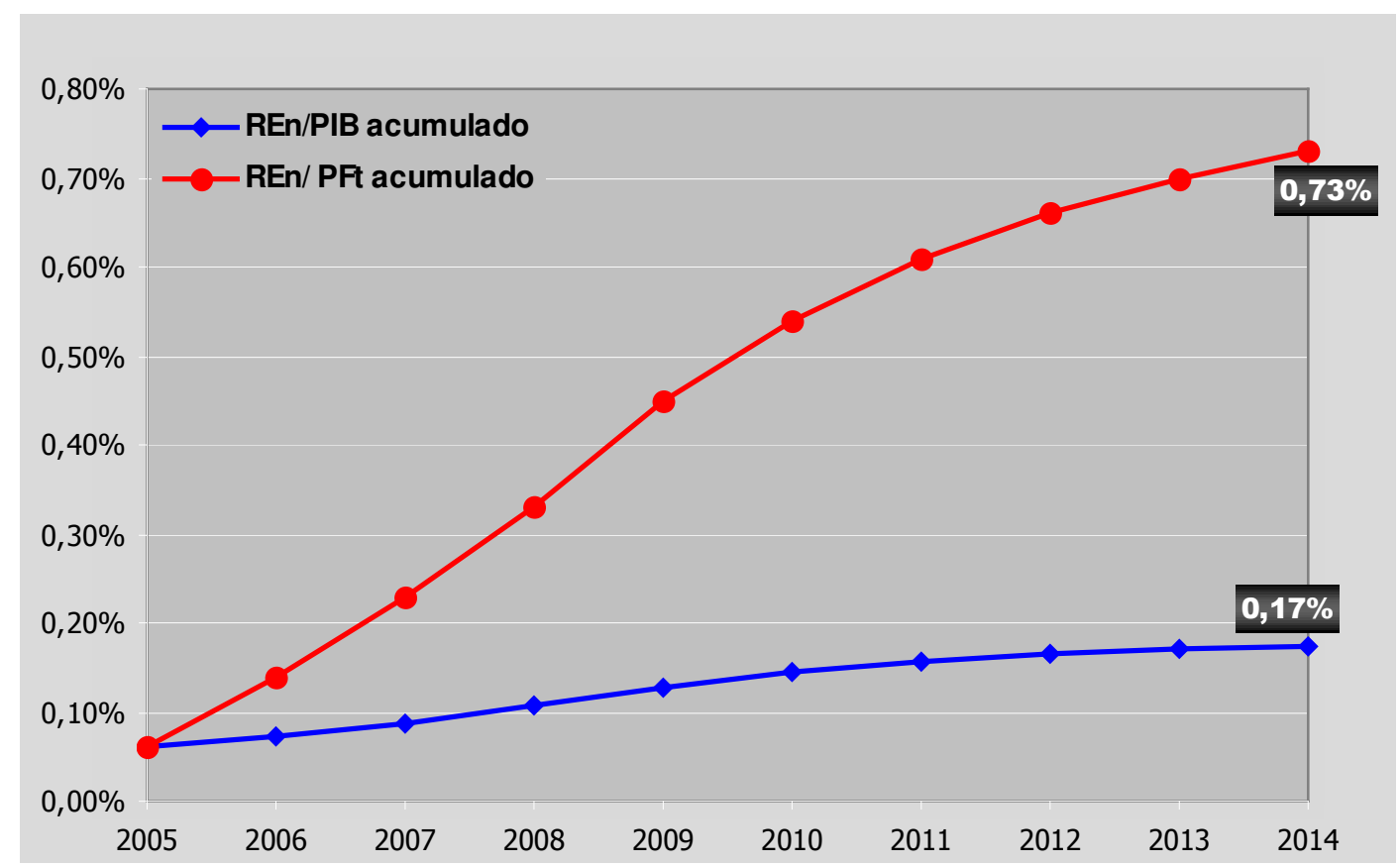

Figura 28 - Expressão do re-direcionamento da poupança financeira para securitização de EELs (simulação para evolução anual do PIB de 4,5\%)

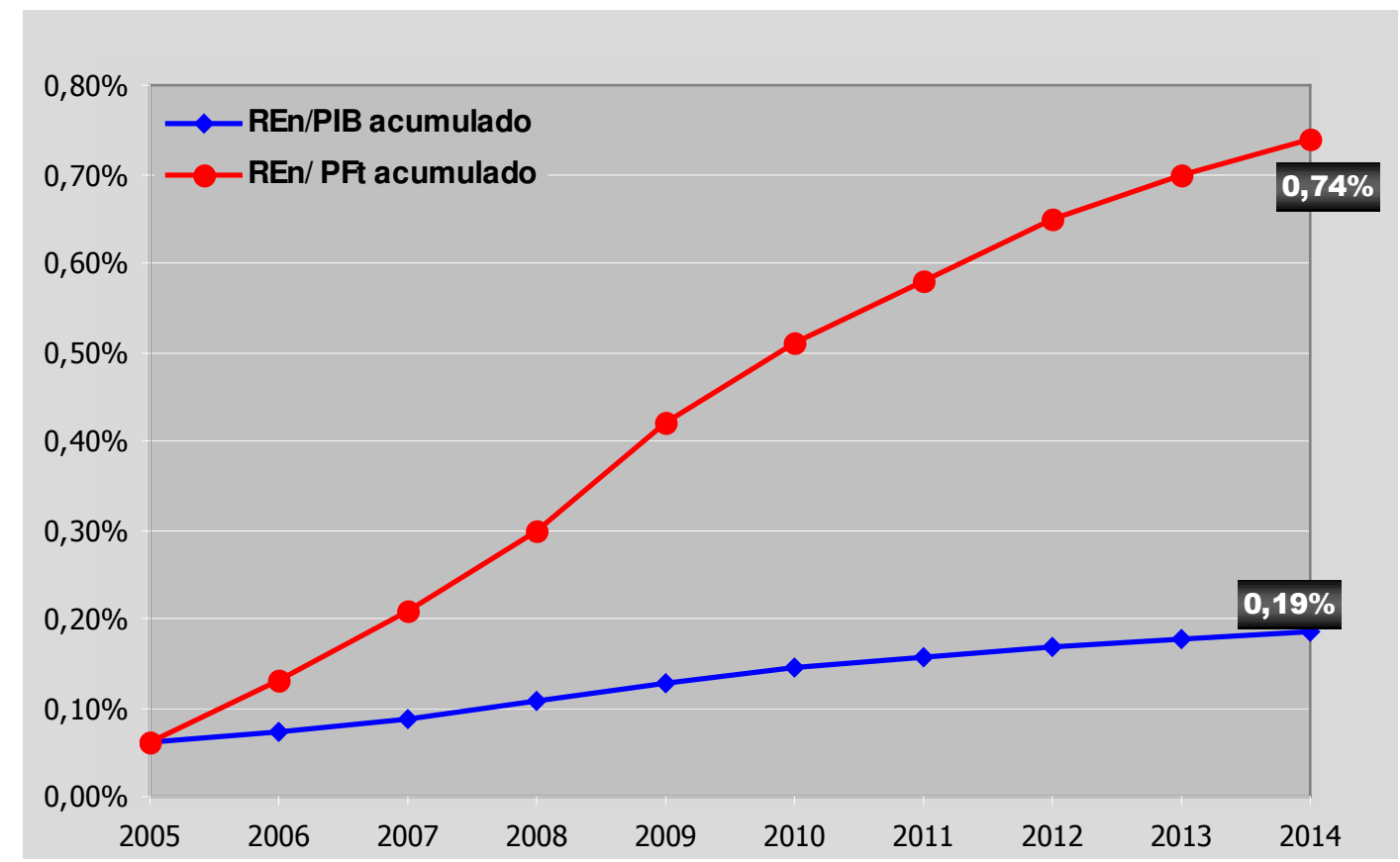

Figura 29 - Expressão do re-direcionamento da poupança financeira para securitização de EELs (simulação para evolução anual do PIB de 2,0\%) 
Vale salientar que a migração de recursos ora aplicados na poupança financeira só é possível para os recursos que sejam realmente conservadores, e não para aqueles que estejam abrigados nas altas taxas de juros do curto prazo. Para os primeiros, os títulos lastreados em EELs são papéis atrativos e alinhados com o objetivo de investimento, como já apresentado anteriormente. Ou seja, existem recursos atualmente aplicados na poupança que não correspondem ao perfil de investimento admitido como válido para EEL: geração de uma renda mensal perene. Desta forma, mesmo com a redução da taxa de juros, é ingênuo afirmar que grande parte dos recursos será atraída para esta migração.

Além disso, é evidente que haverá resistência do re-direcionamento de recursos aplicados diretamente por pessoas físicas, em virtude da falta de conhecimento do mercado e da falta de informações que orientem esta espécie de investimento. A cultura de investimento em ações que, apesar de não oferecem proteções intensas ao risco à parte do peso da marca de grandes empresas, iniciou-se há pouco tempo no mercado brasileiro e teve como vetor de aquecimento a grande disponibilidade de informações sobre as ações de maior expressão. Sendo assim, reconhece-se a necessidade de se disponibilizar e tratar as informações do mercado de EELs de forma a [i] oferecer informações de maior qualidade para o suporte da decisão de empreender, colaborando para a profissionalização do mercado e para a redução dos ciclos recessivos e [ii] oferecer informações para suportar a decisão de se investir em títulos de securitização destes empreendimentos, de forma a subsidiar as decisões de entrada e saída de investidor neste mercado.

Neste contexto, o meio mais rápido de capitalização em torno dos procedimentos de securitização seria atrair para estes títulos os fundos de pensão que têm grande volume de recursos e cultura de investimento em imóveis. A atração destes investidores institucionais seria rápida e ágil, desde que o mercado esteja disposto a oferecer títulos minimamente 
protegidos, evidenciando a preocupação em minimizar as quedas de rentabilidade oriundas de ações especulativas.

Tomando a conjuntura atual para representar a expressão que os fundos de pensão podem ter no mercado de real estate, temos que se o mesmos utilizassem todo o limite de $8 \%$ do volume atual de sua carteira para investimentos em EELs, ter-se-ia um re-direcionamento de aproximadamente 10 bilhões de Reais, valor muito acima daqueles projetados no estudo acima apresentado, o que reforça a expressão e a importância da poupança conservadora para o desenvolvimento do mercado de real estate.

\section{3 O significado do re-direcionamento de recursos da poupanca para o mercado de} $\underline{\text { EEL }}$

Com o intuito de expressar o significado do re-direcionamento de recursos projetado acima, propõe-se a seguir, de forma simplificada, a conversão destes recursos em área bruta rentável de EEL.

- Admitindo, por simplificação, que o re-direcionamento de recursos ocorra para empreendimentos prontos para operar, ou seja, que o investidor pague um preço maior pela ABR já implantada;

- Assumindo que o valor médio das transações de compra de EELs prontos para operar seja de $\mathrm{R} \$ 5.700$ por $\mathrm{m}^{2}$ de $\mathrm{ABR}^{62}$;

- Tomando como produto de referência um edifício de escritórios com $8.000 \mathrm{~m}^{2}$ de ABR (20 andares e $400 \mathrm{~m}^{2}$ de área locável por pavimento-tipo).

\footnotetext{
${ }^{62}$ Conforme parâmetro utilizado no item 5. 8.
} 
Tem-se que o re-direcionamento dos recursos da poupança financeira representaria a inserção de 87 a 105 novos empreendimentos.

Considerando que os recursos sejam investidos na fase de implantação, o preço por $\mathrm{m}^{2}$ de ABR será menor do que o arbitrado acima, já que o empreendedor terá maior alavancagem, necessitando imobilizar menos capital próprio no EEL. Neste caso, a representatividade do redirecionamento de recursos da poupança financeira para os títulos de EELs seria ainda maior.

Obviamente, até que a securitização seja um procedimento sedimentado no mercado, é natural que os investidores optem por aplicar em títulos lastreados em empreendimentos já implantados. Por outro lado, como já tratado anteriormente, é possível a formatação de títulos mais protegidos com relação aos riscos de implantação tomados pelo empreendedor, catalisando o reconhecimento da securitização como procedimento válido e usual no mercado de EELs. 


\section{CONSIDERAÇÕES FINAIS}

A concentração de recursos necessários para a implantação de EELs e o payback de horizonte largo característico destes empreendimentos geram dificuldade na construção da equação de fundos para estes empreendimentos, especialmente em países, como o Brasil, onde não há linhas de crédito voltadas para este setor da economia. Neste contexto, a solução encontrada pelo setor é o partilhamento físico do empreendimento, provocando uma gestão descentralizada que dificulta a manutenção da inserção de mercado do produto ao longo do seu ciclo de vida. Sendo assim, a securitização surge como opção de partilhamento que elimina a questão da descentralização gerencial.

Além disso, a securitização é um vetor de impulsão para o mercado de EELs pela flexibilidade que oferece para a entrada de novos investidores no mercado, dando liquidez ao investimento em imóveis e possibilitando a pulverização da captação de recursos.

Para que a cultura da aplicação de recursos em papéis da securitização de EELs seja sedimentada é necessário que esse procedimento tenha sua expansão em ciclos do mercado de EELs favoráveis ao investimento, uma vez que, em mercados de securitização incipientes, como é o caso do brasileiro, é necessário comprovar a segurança e a rentabilidade do investimento para que se transponha os obstáculos do desconhecimento e do receio injustificado por parte dos investidores. Desta forma, identificou-se como períodos propícios ao desenvolvimento da securitização aqueles caracterizados pela transição do quadrante de recuperação para o de expansão e o próprio quadrante de expansão.

Reconhece-se, entretanto, que o mercado de EELs apresenta alguns entraves além da questão da dificuldade em se aglutinar recursos para empreender. Um obstáculo de grande impacto no desenvolvimento do mercado é a falta de informações disponíveis e a fragilidade da tomada 
de decisão que, usualmente, é feita de forma amadora, sem que haja a devida preocupação com suas conseqüências. Espera-se, no entanto, que o reconhecimento dos pontos a serem aprimorados estimulem a profissionalização do mercado, inibindo a atuação de agentes especuladores via maior divulgação e esclarecimento sobre as informações de mercado.

Em conjunturas onde a necessidade de crescimento é evidente, como ocorre na atual conjuntura econômica brasileira, é plausível considerar um crescimento econômico que impacte na necessidade por novos EELs e, portanto, no aumento da demanda por recursos que sustentem esse desenvolvimento, que, para o mercado de EELs, são aqueles com foco na poupança de longo prazo. Este crescimento econômico deve acontecer pautado na estabilidade da política econômica e na redução das altas taxas de juros praticadas em prol do controle inflacionário que sufocam o setor produtivo da economia, inibindo investimentos.

No presente trabalho, contrariando o pensamento difundido no mercado de que, em cenários onde as altas taxas de juros estão presentes, o investimento ancorado em EELs não é uma opção com rentabilidade competitiva, mostrou-se o inverso, colocando ainda que instrumentos de securitização podem alavancar ainda mais a rentabilidade. No entanto, devese ponderar que, apesar das altas taxas de juros serem obstáculos reais para a captação de recursos com foco no desenvolvimento de EELs, seu efeito maior se dá frente aos setores produtivos da economia, que, em momentos recessivos, reduzem sua atuação e conseqüentemente a demanda por EELs, reduzindo as taxas de ocupação e provocando quebras de desempenho e rentabilidade dos investimentos ancorados nestes produtos.

Nota-se ainda que é possível utilizar o re-direcionamento de recursos alocados na poupança financeira para vetores de securitização, suportando em grande parte o desenvolvimento do mercado de EELs. Neste sentido, os fundos de pensão, mesmo com as restrições feitas à sua 
carteira no que tange às aplicações de recursos, desempenharão papel fundamental para que a securitização seja um procedimento consagrado e culturalmente aceito no mercado brasileiro.

É importante frisar, entretanto, que não basta encontrar novas formas de aglutinação de capitais para o desenvolvimento de EELs, é necessário que haja a disponibilidade de insumos e mão-de-obra capazes de atender o desenvolvimento deste mercado. Portanto, o crescimento não pode ser expressivo em apenas alguns setores econômicos, e não se pode visualizá-lo apenas como gerador de demanda de novos espaços de escritório. É necessário que o crescimento se dê de forma sustentável, evitando assim ações especulativas nos mais diversos setores que, de uma forma ou de outra, sempre terão impactos maléficos para o desenvolvimento do país. Neste sentido, cabe ao governo o papel de regular o desenvolvimento econômico através de incentivos e regulamentações que propiciem um crescimento sustentável para o Brasil. 


\section{LISTA DE REFERÊNCIAS}

ABRAPP - Associação Brasileira das Entidades Fechadas de Previdência Complementar. Brasil. Apresenta dados estatísticos sobre a atuação das entidades de previdência complementar. Disponível em: <http://www.abrapp.org.br> Acesso em: 02 de abril de 2006.

Alencar, Claudio Tavares DE. Derivação de fundos para investimento em empreendimentos de infra-estrutura no Brasil: a viabilidade da securitização nas concessões rodoviárias e de geração independente de energia elétrica. São Paulo, 1998. 281p. Tese (Doutorado) - Escola Politécnica da Universidade de São Paulo

O Equilíbrio entre a Sustentabilidade e a Atratividade do Investimento em Edifícios de Escritórios para Locação em São Paulo. Anais em CD-ROM. X Encontro Nacional de Tecnologia do Ambiente Construído (ENTAC'2004) - I Conferência Latino-Americana de Construção Sustentável (claCS’04). 11 p. São Paulo, Brasil, 18 a 21 de julho, 2004.

Alencar, C. T.; Monetti, E. Office Buildings Market in São Paulo: The Balance Between Sustainability and Investment Attractiveness. Anais em CD-ROM. XXXII International Association of Housing Science World Congress. 12 p. Trento, Itália, 21 a 25 de setembro, 2004.

Antonioli, P. E; GraÇA, M.E.A., J. Subsídios conceituais para o planejamento de sistemas de gerenciamento de facilidades em edificações produtivas. São Paulo, 2004. 26p. (Boletim Técnico da Escola Politécnica da USP. Departamento de Engenharia de Construção Civil, BT/PCC/358).

ARAGÃO, IRACEMA MACHADO DE. Contribuições à análise de risco de crédito de empresas construtoras e/ou incorporadoras de empreendimentos imobiliários. São Paulo, 1998. 152p. Dissertação (Mestrado) - Faculdade de Economia, Administração e Contabilidade da Universidade de São Paulo.

ARAÚJO, StÊNIO BRASIL ACCIOLY DE. Caracterização de um índice de valor para o mercado de investimentos em edifícios de escritórios destinados à locação. São Paulo, 2005. 130p. Dissertação (Mestrado) - Escola Politécnica da Universidade de São Paulo.

BANCO CENTRAL Do BRASIL. Brasil. Apresenta informações sobre a economia brasileira. Disponível em: <http://www.bcb.doc.gov/> Acesso em: 11 de agosto de 2005.

BNDES - Banco Nacional de Desenvolvimento Econômico e Social. Brasil. Apresenta em linhas gerais as regras para o Financiamento a Empreendimentos (Programa FINEM). Disponível em: <http://www.bndes.gov.br/linhas/finem.asp> Acesso em: 27 de julho de 2005.

BOVESPA - Bolsa de Valores de São Paulo. Brasil. Apresenta a descrição e a metodologia para a obtenção do Ibovespa Disponível em: 
<http://www.bovespa.com.br/Mercado/RendaVariavel/Indices> Acesso em: 02 de abril de 2006.

BRASIL. Presidência da República Federativa do Brasil. Lei no 6.435, de 15 de julho de 1977. Dispõe sobre a constituição, a organização e o funcionamento de entidades de previdência privada. Disponível em: <http://www.planalto.gov.br/CCIVIL/ LEIS/L6435.htm> Acesso em: 05 de abril de 2006.

BRASIL. Ministério da Previdência Social - Secretaria de Previdência Complementar. Informe Estatístico - julho/ 2005. Apresenta dados estatísticos relativos às entidades fechadas de previdência complementar. Disponível em: <http://www.previdencia.gov.br/08.asp> Acesso em: 05 de abril de 2006.

Bureau of ECONOMIC ANALysis - U.S. DePARTMENT OF COMMERCE. Estados Unidos. Apresenta informações sobre a economia americana. Disponível em: $<$ http://www.bea.doc.gov/> Acesso em: 11 de agosto de 2005.

CEF - Caixa Econômica Federal. Brasil. Apresenta informações sobre fundos de investimento imobiliário. Disponível em: <http://www.caixa.gov.br/voce/produtos/ fundos_de_investimento/fundos_imobiliarios> Acesso em: 02 de abril de 2006.

CYrela Brazil REALTy. Brazil. Apresenta informações sobre a atuação da empresa no mercado de incorporação imobiliária e sobre a participação do setor da construção civil na economia brasileira. Disponível em: <http://ri.brazilrealty.com.br> Acesso em: 16 de janeiro de 2006.

Instituto Brasileiro de Geografia e Estatística (IBGE). Pesquisa Anual da Indústria da Construção. Rio de Janeiro, 2003. Disponível em < http://www.ibge.gov.br> Acesso em: 10 de novembro de 2005.Jones Lang LaSalle. Perfil Imobiliário - São Paulo, Balanço 2002. Disponível em: <http://www.joneslanglasalle.com.br>. Acesso em: 25 de junho de 2005

MINISTÉRIO DA FAZENDA. Brasil. Apresenta, entre outros, notícias referentes às determinações do Banco Central a fim de regulamentar a operação das instituições financeiras. Disponível em: <http://www.fazenda.gov.br/portugues/releases/ 2002/r020812b.asp> Acesso em: 24 de março de 2006.

NAREIT - NATIONAL ASSOCIATION OF REAL ESTATE INVESTMENT TRUSTS. Apresenta números e informações do mercado de REITs americanos. Disponível em: $<$ http://www.nareit.com>. Acesso em: 8 de agosto de 2005.

NÚCLEO DE REAL ESTATE. Estudo setorial sobre edifícios comerciais preparado para um fundo de previdência privada. São Paulo, 2002. Escola Politécnica da USP.

NRE - NÚCLEO DE REAL ESTATE. Apresenta informações sobre Real Estate, e presta serviços de classificação de edifícios de escritórios para do mercado brasileiro. Disponível em: <http://www.realestate.br/>. Acesso em: 26 de janeiro de 2006. 
PARK, JAE Won. Securitização de Empreendimentos de Base Imobiliária. São Paulo, 1997. 120p. Dissertação (Master in Business Administration - Área de Concentração: Finanças) - EAESP/FGV.

Rieche, Fernando Ceschin. Gestão de Riscos em Fundos de Pensão no Brasil: Situação Atual da Legislação e Perspectivas. Brasil, 2005. 31p. Disponível em:

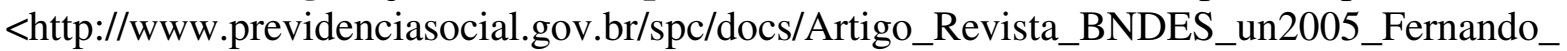
Rieche.pdf $>$. Acesso em: 05 de abril de 2006.

Rocha Lima JR., J. Análise econômica de empreendimentos de longo horizonte de maturação: indicadores avançados para análise da qualidade do investimento. São Paulo, 2001a. 24p. (Boletim Técnico da Escola Politécnica da USP. Departamento de Engenharia de Construção Civil, BT/PCC/271).

Decidir sobre investimentos no setor da Construção Civil. São Paulo: EPUSP, 1998a. 72 p. (Boletim Técnico da Escola Politécnica da USP. Departamento de Engenharia de Construção Civil, BT/PCC/200).

Decisão e Planejamento: Fundamentos para a Empresa e Empreendimentos na Construção Civil. São Paulo: EPUSP, 2004. 54 p. (Texto Técnico da Escola Politécnica da USP. Departamento de Engenharia de Construção Civil, TT/PCC/25).

Formação da taxa de retorno em empreendimentos de base imobiliária. São Paulo: EPUSP, 1998b. 33 p. (Boletim Técnico da Escola Politécnica da USP. Departamento de Engenharia de Construção Civil, BT/PCC/218).

Fundos de Investimento Imobiliário e Real Estate Investment Trusts. 7 p. In: Congresso Urban Land Institute - Real Estate na América Latina, 2001, São Paulo. 2001b

Fundos de investimento imobiliário e títulos de investimento de base imobiliária. São Paulo: EPUSP, 1994. 33 p. (Boletim Técnico da Escola Politécnica da USP. Departamento de Engenharia de Construção Civil, BT/PCC/130).

Investimento em empreendimentos de base imobiliária: significado da renda garantida. São Paulo, 2006. 6 p. (Carta do NRE da Escola Politécnica da USP. Departamento de Engenharia de Construção Civil, março-abril 2006).

_. Novos produtos financeiros e o mercado imobiliário. Investimentos via títulos de securitização. São Paulo, 1999a. 24p. Escola Politécnica da USP. Departamento de Engenharia de Construção Civil.

.Recursos para empreendimentos imobiliários no Brasil - Debêntures e Fundos. São Paulo, EPUSP, 1990. 47p. (Boletim Técnico. Escola Politécnica da USP. Departamento de Engenharia de Construção Civil, BT/28-90) 
Títulos de Investimento com lastro em ativos. $O$ mercado brasileiro à espera de um líder. São Paulo, 1999b. 25p. Escola Politécnica da USP. Departamento de Engenharia de Construção Civil.

Rocha Lima, J.; Alencar, C. T. O Mercado de Edifícios de Escritórios para Locação em São Paulo: Ciclos para Absorção do Estoque e Retomada da Atratividade do Investimento. Estudos Econômicos da Construção. Fundação Getúlio Vargas, v.6, n.1 (9), p.1-25. São Paulo, 2004a.

O Mercado de Edifícios de Escritórios para Locação em São Paulo: O Ciclo 20002003 - da Euforia à Crise. Conjuntura da Construção (separata da Conjuntura Econômica). Fundação Getúlio Vargas, v.1, n.2, p.10-11. São Paulo, 2004.

ROCHA LIMA, J.; TAKAOKA M. V. Investimentos para formação de carteira de poupança para complemento de renda mensal no Brasil. Comparação entre diferentes instrumentos disponíveis no mercado. São Paulo, 2006. No prelo.

SAntovito, Rogério Fonseca. A dinâmica do mercado de edifícios de escritórios e a produção de indicadores de comportamento: uma simulação do índice de preços de locação em regiões de ocupação típica na cidade de São Paulo. São Paulo, 2004. 137. Dissertação (Mestrado) - Escola Politécnica da Universidade de São Paulo.

SÃO PAULO. Prefeitura do Município de São Paulo. Lei no 13.430, de 13 de setembro de 2002. Institui o Plano Diretor Estratégico e o Sistema de Planejamento e Gestão do Desenvolvimento Urbano do Município de São Paulo. Disponível em: <http://portal.prefeitura.sp.gov.br/secretarias/planejamento/plano_diretor/> Acesso em: $27 \mathrm{de}$ julho de 2005.

SÃO PAULO. Prefeitura do Município de São Paulo. Lei no 13.885, de 25 de agosto de 2004. Institui o Plano Diretor Estratégico e o Sistema de Planejamento e Gestão do Desenvolvimento Urbano do Município de São Paulo. Disponível em: $<$ http://portal.prefeitura.sp.gov.br/secretarias/planejamento/zoneamento/> Acesso em: $27 \mathrm{de}$ julho de 2005.

SÃO PAULO. Prefeitura do Município de São Paulo. Decreto $\mathbf{n}^{\mathbf{0}}$ 43.232, de 22 de maio de 2003. Regulamenta a outorga onerosa de potencial construtivo adicional do Município de São Paulo. Disponível em: <http://portal.prefeitura.sp.gov.br/ secretarias/planejamento/plano_diretor/decretos/> Acesso em: 27 de julho de 2005.

TAKAOKA, MARCELO VESPOLI. Método para rating de volatilidade dos indicadores da qualidade de valores mobiliários resultantes da securitização de empreendimentos de base imobiliária. São Paulo, 2003. 156p. Dissertação (Mestrado) - Escola Politécnica da Universidade de São Paulo.

UNITAS DistRIBUIDORA DE TÍTULOS E VALORES. Apresenta aspectos sobre a securitização. Disponível em http://www.unitas.com.br/. Acesso em: 18 de julho de 2003. 
VedRossi, AlesSANDRO OIZON. A securitização de recebíveis imobiliários: uma alternativa de aporte de capitais para empreendimentos residenciais no Brasil. São Paulo, 2002. 111p. Dissertação (Mestrado) - Escola Politécnica da Universidade de São Paulo.

Vedrossi, A.O.; MONETTI, E._A securitização de recebíveis imobiliários: uma alternativa de aporte de capitais para empreendimentos residenciais no Brasil. São Paulo, EPUSP, 2002. 20p. (Boletim Técnico. Escola Politécnica da USP. Departamento de Engenharia de Construção Civil, BT/PCC/326)

Veronezi, Ana Beatriz Poli. Sistema de certificação da qualidade de edifícios de escritórios no Brasil. São Paulo, 2004. 146p.+apêndice. Dissertação (Mestrado) - Escola Politécnica da Universidade de São Paulo.

Whenton, W.C. The Cyclic Behaviour of The National Office Market. Journal of American Real Estate and Urban Economics Association, v. 15, n. 4, p. 281-299, 1987. 